\title{
The Top 50 Commodity Chemicals: Impact of Catálytic' Process Limitations on Energy, Environment, and Economics
}

August 1995

Prepared for the U.S. Department of Energy,

Office of Industrial Tèchnology (OIT)

Biological and Chemical Technologies

Research (BCTR) Program.

under Contract DE-AC06-76RLO 1830

Pacific Northwest Laboratory

Operated for the U.S. Department of Energy

by Battelle Memorial Institute 


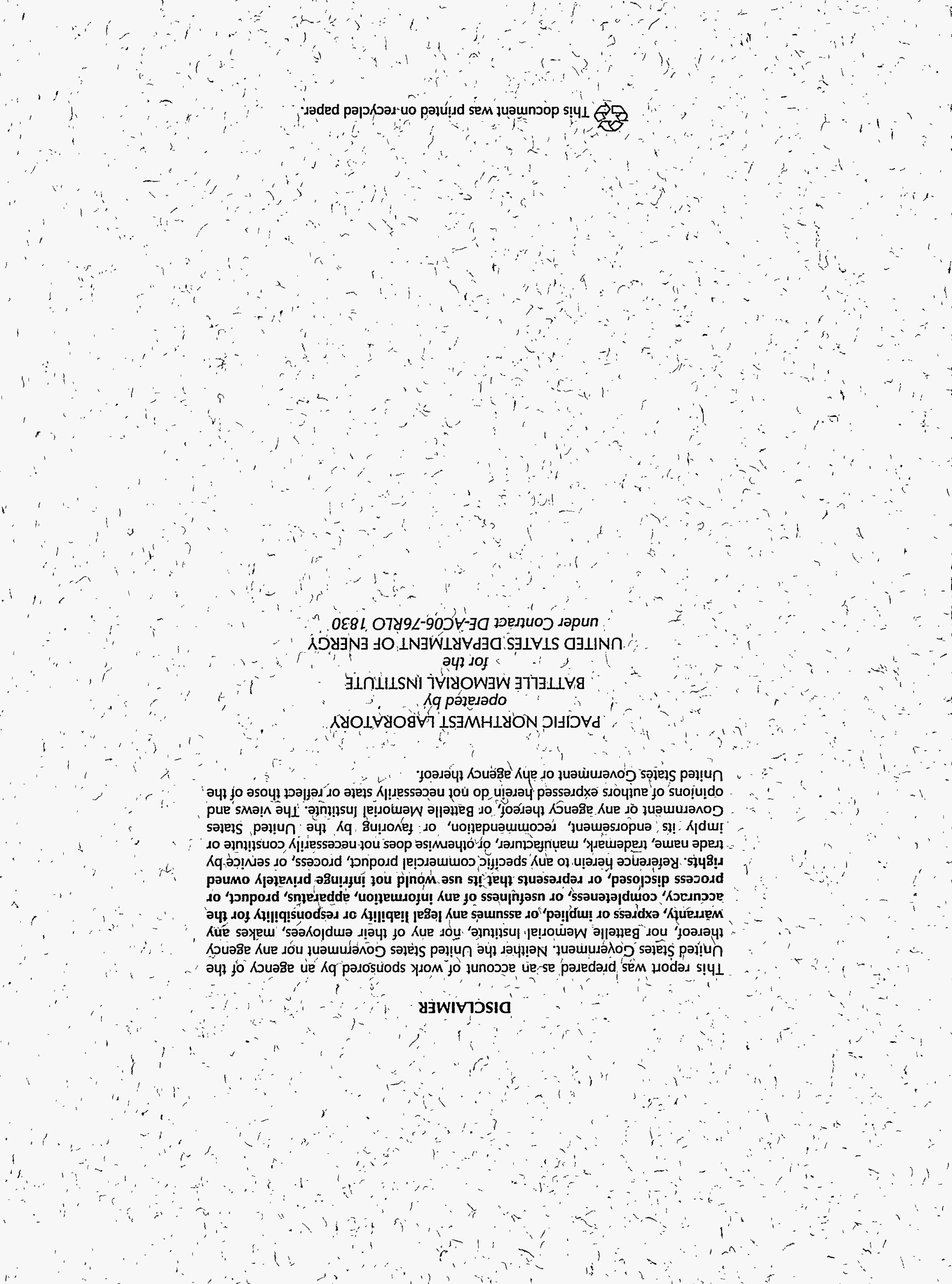


PNL-10684

UC-601

\section{The Top 50 Commodity. Chemicals:}

Impact of Catalytic Process Limitations on Energy, Environment, and Economics

Anna Lee Y. Tonkovich, Ph.D.

Mark A. Gerber

August 1995

Prepared for the U. S. Department of Energy, Office of Industrial Technology (OIT), Biological and Chemical Technologies Research (BCTR) Program under contract DE-AC06-76RLO 1830

Pacific Northwest Laboratory '

Richland, WA 99352 


.

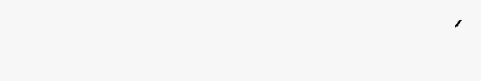




\section{DISCLAIMER}

Portions of this document may be illegible in electronic image products. Images are produced from the best available original document. 


\section{Executive Summary}

The production processes for the top $50 \mathrm{U}$.S. commodity chemicals waste energy, generate unwanted byproducts, and require more than a stoichiometric amount of feedstocks. Pacific Northwest Laboratory ${ }^{2}$ has quantified this impact on energy, environment, and economics for the catalytically produced commodity chemicals. An. excess of 0.83 quads of energy per year in combined process and feedstock energy is required. The major component, approximately 54\%, results from low per-pass yields and the subsequent separation and recycle of unreacted feedstocks. Furthermore, the production processes, either directly or through downstream waste treatment steps, release more than 20 billion pounds of carbon dioxide per year to the environment. The cost of the wasted feedstock exceeds 2 billion dollars per year. Process limitations resulting from unselective catalysis and unfavorable reaction thermodynamic constraints are the major contributors to this waste. Advanced process concepts that address these problems in an integrated manner are needed to improve process efficiency, which would reduce energy and raw material consumption, and the generation of unwanted byproducts.

Many commodity chemicals are used to produce large volume polymer products. Of the energy and feedstock wasted during the production of the commodity chemicals, nearly one-third and one-half, respectively, represents chemicals used as polymer precursors. Approximately $38 \%$ of the carbon dioxide emissions are generated producing polymer feedstocks.

a Pacific Northwest Laboratory is operated for the U. S. Department of Energy by Battelle Memorial Institute under contract DE-AC06-76RLO 1830. 


\section{Contents}

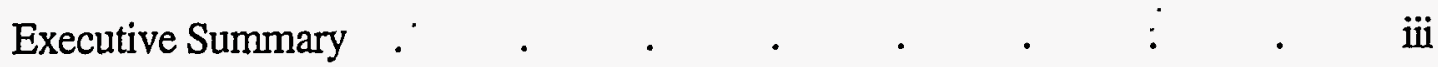

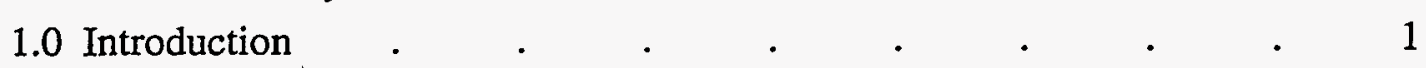

2.0 Methodology . . . . . . . . . 3

2.1 Energy Calculations . . . . . . . . 3

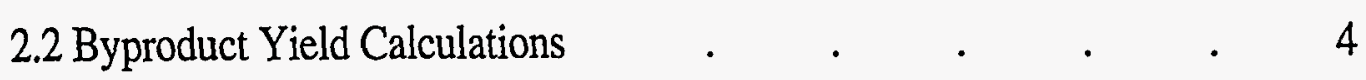

2.3 Total Wasted Feedstock Calculations . $\quad$. $\quad$. $\quad$. 5 .

2.4 Cost of Wasted Feedstock Calculations . . . . . 6

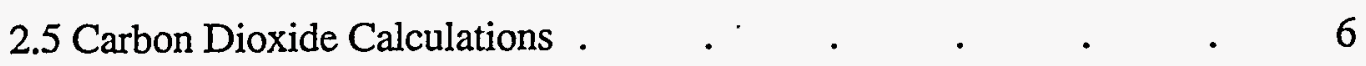

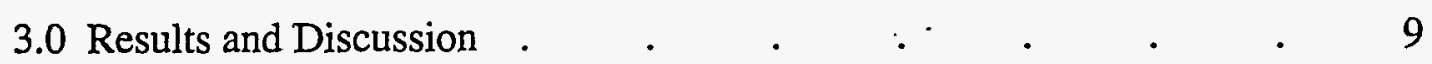

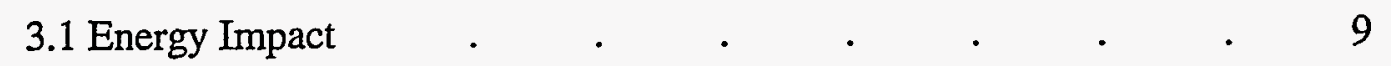

3.1.1 Process Energy Saved from Improving Overall Yields . 9

3.1.2 Feedstock Energy Saved from Improving Overall Yields . 11

3.1.3 Process Energy Saved from Improving Per-Pass Yields 12

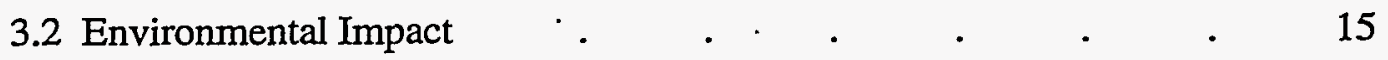

3.3 Economic Impact . $\quad . \quad$. $\quad$. . . . . 16

3.4 Process Limitations . $\quad . \quad$. $\quad$. $\quad$. $\quad$. $\quad$. 18

3.5 Impact on Top 12 Polymers . . . . . . . 20

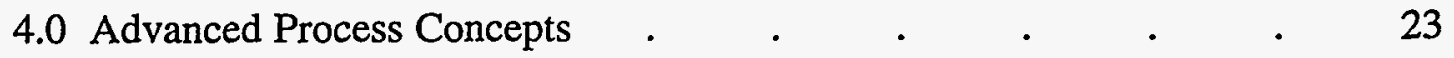

4.1 Catalysis Design and Development . . . . . . 23

4.2 Reactor Design $\quad . \quad$. $\quad$. $\quad$. $\quad$. $\quad$. $\quad$. 24

4.3 Integrated Process Design . . . . . . . 25

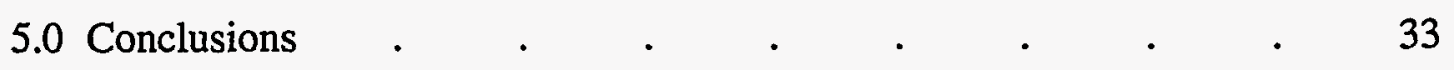

6.0 References and Bibliography $\quad . \quad$. $\quad . \quad$. $\quad . \quad$. 35

Appendix I: Potential feedstock and process energy savings calculations

Appendix II: Calculation of excess feedstock required and carbon dioxide generated Appendix II: Process information and limitations 


\subsection{Introduction}

Catalytically produced commodity chemicals represent an important cross-section of the U. S. chemical and petrochemical industry. The impact of the inefficiencies found in these production routes is magnified by the large annual volume of materials produced. The corresponding impact of these process inefficiencies on energy consumption, unwanted byproduct formation, and added economic burdens is a driver for process improvements. Identification of the most impactful areas for targeted research is a goal of the U.S. Department of Energy, Office of Industrial Technology.

The purpose of this study conducted for DOE by Pacific Northwest Laboratory (PNL) was to quantify the combined impact of energy, environment, and economics on the catalytically produced top 50 commodity chemicals. An initial estimate of the energy savings that would result from raising the overall process yields to their theoretical maximum concluded that an excess of $0.47 \mathrm{Q} / \mathrm{yr}$ was required (Tonkovich 1994). The 1994 study evaluated each product as if it were produced by a "black-box" single-pass process that had a linear relationship between process yield and energy. The current study examines each chemical production route in greater detail to describe realistic processes that are often multiple pass and incorporate energetically and environmentally expensive separation and reactant recycle steps. For example, a process that may have an overall yield of $90 \%$ was assumed to have a maximum process and feedstock energy savings of $10 \%$. In reality, this process may have a per-pass yield of $10 \%$, which corresponds to a $10 \%$ savings in feedstock energy, but up to a $90 \%$ savings in process energy. These revised numbers have been used in the calculations for this study.

Process limitations that account for possible energy savings were estimated and grouped. The primary process limitations are as follows: equilibrium limitations for the main reaction, equilibrium limitations for competing reactions, kinetic limitations for the main reaction, kinetic limitations from competing reactions (including overoxidation and over alkylation), catalyst deactivation, heat addition, heat removal, and mass transfer limitations. No attempt was made to assign fractional impact values for those chemicals subject to more than one problem. These limitations are interdependent and would necessitate further in-depth study to assess their true relative importance. The impact from each category was summed and normalized to prioritize the relative importance of the various process limitations.

The environmental impact associated with the production of the top 50 chemicals was partially estimated and quantified. The byproducts of the carbonaceous feedstocks were 
cited. Carbon dioxide was the most common byproduct. It is either formed directly in the process or generated downstream by flaring carbonaceous byproducts or from other waste treatment conversion processes. In these cases, an equivalent carbon dioxide production value is calculated. For example, the primary side product for the production of ethylene oxide is carbon dioxide. The wasted feedstock is assumed to be fully converted to carbon dioxide in the amount of approximately 3.5 billion lb/yr. Another example is the production of styrene. While carbon dioxide is not produced directly, tars and other highly polymerized side products are co-produced with styrene. These heavy hydrocarbons are later incinerated and produce approximately 2.5 billion $\mathrm{lb} / \mathrm{yr}$ of carbon dioxide.

Economic impact was estimated by summing the value of each wasted feedstock. This estimate is low and does not reflect potential capital and operating savings that would result from more efficient processes. The price per pound of each feedstock was obtained from Chemical Marketing Reporter (May 8, 1995). 


\subsection{Methodology}

\subsection{Energy Calculations}

The maximum potential energy savings for each of the top 50 production routes is calculated in three steps. The first evaluates the partial impact on process energy by improving the overall process yield from current values to $100 \%$ :

$$
\mathrm{E}_{\text {saved-process }}=\quad \begin{aligned}
& \text { [production rate] } \times \text { [process energy }] \times[1-\text { fractional } \\
& \text { process yield }] /[\text { fractional process yield }]
\end{aligned}
$$

The amount of feedstock to be processed is lowered, and thus the corresponding processing energy is reduced. The second step calculates the feedstock energy saved from improving the overall process efficiency and requiring fewer raw materials:

$$
E_{\text {saved-feedstock }}=\quad \begin{aligned}
& \text { [production rate }] \mathrm{x}[\text { feedstock energy-w/o double counting }]^{\mathrm{b}} \\
& \mathrm{x}[1 \text {-fractional process yield }] /[\text { fractional process yield }]
\end{aligned}
$$

The third step estimates the potential process energy savings that would result from raising per-pass yields. A new process energy.(Btu/lb) is calculated which reflects a more efficient process that requires only a stoichiometric amount of feedstock:

$$
\text { Process_energy } \left.\left.y_{\text {new }}(\mathrm{Btu} / \mathrm{lb})=\text { [Old process energy }\right] \mathrm{x} \text { [fractional process yield }\right]
$$

This new process energy number is then used to calculate potential savings from driving the reaction to completion in a single pass.

$$
\mathrm{E}_{\text {saved-per_pass }}=\quad \begin{aligned}
& \text { [Process_energynew } \\
& \text { pass conversion }]
\end{aligned} \times[\text { production rate }] \times[1-\text { fractional per }
$$

The total energy savings is calculated by summing the individual components.

$$
E_{\text {total }}=E_{\text {saved-process }}+E_{\text {saved-per_pass }}+E_{\text {saved-feedstock }}
$$

The amount of carbon dioxide formed is determined by first calculating the amount of feedstock that is converted to no-value byproducts. Many processes co-produce other

b calculated by Tonkovich (1994) 
șaleable products, whose product selectivity is added with that of the desired (top 50) chemicals. Using combustion stoichiometry, the moles of carbon dioxide produced are calculated and converted into lb/year that are vented to the environment. Some processes do not produce carbon dioxide directly, but they do generate other no-value carbonaceous products, which are later flared or biologically converted to carbon dioxide. These are also included in the carbon dioxide calculation.

The extra feedstock cost is calculated by multiplying the excess $1 \mathrm{~b} /$ year feedstock required by the current value of this feedstock (as defined by Chemical Marketing Reporter).

The following are sample calculations used to determine byproduct yield, total feedstock conversion to product and byproducts, feedstock wasted, cost of feedstock wasted, and the carbon dioxide equivalent to the feedstock wasted.

\subsection{Byproduct Yield Calculations}

Byproduct data from the literature were expressed in one of four ways: 1) as a mole \% yield based on a reactant, 2) as a difference between the total feedstock converted and the product yield, 3 ) as a weight fraction based on the amount of product produced, and 4) as a $\%$ selectivity to the byproduct based on the converted reactant. The first case requires no calculation.

The second case is used only in those circumstances of catalytic reforming of ethane to produce propylene, and naphtha to produce benzene, toluene, and xylene (BTX) and ethylbenzene, where all of the products are either separated and recovered or used as a mixture for olefin or gasoline manufacture:

\%yield ${ }_{\text {byproduct }}=100-\%$ yield $_{\text {product }}$

Example: production of hydrocarbon byproducts from catalytic reforming of ethane to propylene

Propylene yield $=1.71 \%$

\%yield byproduct $=100-1.71=98.29 \%$ 
The third case requires a conversion of the weight $\%$ of the byproduct to a mole $\%$ based on the product multiplied by the product yield:

$$
\begin{aligned}
\text { \%yield } & \text { byproduct } \\
& =\text { yield }_{\text {product }} *(\text { wt fraction })_{\text {byproduct }} *(\text { mole wt })_{\text {product }} /(\text { mole } \\
& \text { wt })_{\text {byproduct }}
\end{aligned}
$$

Example: byproduct yield of toluene from styrene synthesis:

$$
\begin{aligned}
\text { styrene yield } & =90 \% \\
\text { byproduct yield } & =31 \mathrm{lb}_{\text {toluene }} / 1000 \mathrm{lb} \text { styrene }=.031 \\
\text { mole wt styrene } & =104 \\
\text { mole wt toluene } & =92 \\
& \% \text { yield } \\
\text { toluene } & =90 \% * .031 * 104 / 92=3.15 \%
\end{aligned}
$$

The fourth case is applied to those circumstances where a byproduct or a co-product is formed and the selectivity is provided. This case requires a calculation of the yield by multiplying the reactant conversion by the selectivity of the process to the byproducts:

$$
\text { \%yield } \text { byjproduct }=\% \text { conversion }_{\text {reactant }} *(\text { selectivity })_{\text {byproduct }}
$$

Example: production of diethylene glycol and triethylene glycol during ethylene glycol manufacture:

Total conversion of ethylene oxide $=99 \%$

Selectivity of ethylene oxide conversion to diethylene and triethylene glycol products $=0.1$

yield $_{\mathrm{di} \text {-and tri-ethylene glycols }}=99 \% * 0.1=9.9 \%$ 


\subsection{Total Wasted Feedstock Calculations}

Total feedstock wasted is determined by calculating the amount of feedstock required to yield the amount of product and subtracting from that the amount that was converted to product and byproduct:

$$
\text { feedstock }_{\text {wasted }}=\text { feedstock }_{\text {required }} *\left[1-\left(\text { yield }_{\text {product }}+\text { yield }_{\text {byproduct }}\right)\right]
$$

where the feedstock required $=$ product made/yield product

Example: feedstock wasted for production of styrene:

$$
\begin{aligned}
& \text { styrene }(\text { mole } \mathrm{wt}=104) \text { produced }=8.94 \text { billion } \mathrm{lb} / \mathrm{yr} \\
& \text { styrene yield from ethylbenzene }=90 \mathrm{~mol} \% \\
& \text { toluene byproduct yield } \quad=3.15 \% \\
& \text { mole wt } \text { styrene } \quad=104 \\
& \text { mole wt } \mathrm{t}_{\text {ethylbenzene }} \quad=106 \\
& \text { ethylbenzene wasted }=8.94\left(10^{8}\right) / 104 / 90 * 106^{*}[100-(90+3.15)]=6.93\left(10^{8}\right) \mathrm{lb} \\
& =0.693 \text { billion } \mathrm{lb}
\end{aligned}
$$

\subsection{Cost of Wasted Feedstock Calculations}

The annual cost of feedstock wasted is calculated by multiplying the amount of feedstock wasted by the unit cost of the feedstock: :

cost feedstock wasted $=$ unit feedstock cost $*$ feedstock wasted

Example: cost of ethylbenzene wasted during the production of styrene:

ethylbenzene wasted $=6.93\left(10^{8}\right) \mathrm{lb}$

ethylbenzene unit cost $=\$ 0.27 / \mathrm{lb}$

cost of ethylbenzene $=6.93\left(10^{8}\right) \mathrm{lb} * \$ 0.27 / \mathrm{lb}=\$ 01.87\left(10^{8}\right)=\$ 0.187$ billion 


\subsection{Carbon Dioxide Calculations}

The carbon dioxide equivalent to the feedstock wasted is determined by calculating the $\mathrm{lb}$ of $\mathrm{CO}_{2}$ produced from each $\mathrm{lb}$ of feedstock and multiplying this amount by the $\mathrm{lb}$ of feedstock wasted:

$\mathrm{CO}_{2}$ equivalent $=\mathrm{lb}_{\text {feedstock }}$ wasted $/ \mathrm{mol}_{\text {w }} \mathrm{t}_{\text {feedstock }} * \mathrm{~mol}_{\text {carbon }} / \mathrm{mol}_{\text {feedstock }}$ * $\mathrm{lb}_{\mathrm{CO} 2} / \mathrm{mol}_{\text {carbon }}$

Example: $\mathrm{CO}_{2}$ equivalent of ethylbenzene wasted for production of styrene:

$\begin{array}{ll}\text { ethylbenzene wasted } & =6.93\left(10^{8}\right) \mathrm{lb} \\ \text { mol wt }_{\text {ethylbenzene }} & =106 \\ \text { mole carbon }_{\text {ethylbenzene }} & =8 \\ \text { mole wt } \mathrm{CO}_{2} & =44\end{array}$

$\mathrm{CO}_{2}$ equivalent $=\left[6.93\left(10^{8}\right) / 106\right] * 8 * 44=2.3\left(10^{8}\right) \mathrm{lb}$ 


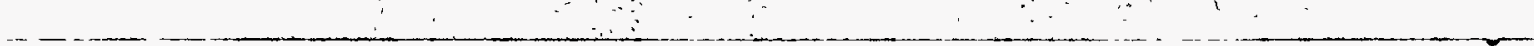




\subsection{Results and discussion}

The production routes of the top 50 commodity chemicals were evaluated to assess the impact of process inefficiencies on energy, environment, and economics. An initial investigation (Tonkovich 1994) concluded that $0.47 \mathrm{Q} / \mathrm{yr}$ could be saved by improving the overall process yields to their theoretical maximum. The current study delves more deeply into the underlying phenomena that create these process inefficiencies and attempts to separate and quantify the possible energy savings from improving both the per-pass yields and the overall process yields. The environmental and economic impact of the waste that is co-generated with the saleable products are also quantified.

\subsection{Energy Impact}

The energy savings was divided into three main components: process energy saved from improving the overall yield, feedstock energy saved from raising the overall process yields, and the additional process energy saved from raising the per-pass yields. The primary assumption used to complete these calculations was a linear impact between yield improvement and energy savings. In reality, the relationship between energy and yield might vary from chemical to chemical and may stray from linearity.

In most cases, the overall process yield values were those cited earlier (Tonkovich 1994). In a few cases, new process yield data was obtained from the literature. These new values lower the calculated savings reported in the 1994 study from 0.47 to $0.38 \mathrm{Q} / \mathrm{yr}$. The primary discrepancy is the omission of the BTX chemicals from the current study because they produce saleable byproducts rather than waste.

\subsubsection{Process Energy Saved from Improving Overall Yields}

For a generic process that sees a process yield improvement, there are fewer feedstocks required to achieve the desired production level. This reduction in the amount of material that must be heated, cooled, transported, and separated improves process efficiency. The calculated savings in process energy resulting from processes with higher overall yields summed over the 30 catalytically produced chemicals is $0.1459 \mathrm{Q} / \mathrm{yr}$ (see Table 1). 
Table 1. Process Energy Savings from Overall Yield Improvements

\begin{tabular}{|l|c|c|c|c|}
\hline \multicolumn{1}{|c|}{ Chemical } & Process yield & $\begin{array}{c}\text { Process } \\
\text { selectivity }\end{array}$ & $\begin{array}{c}\text { Process energy } \\
\text { (Btu/lb) }\end{array}$ & $\begin{array}{c}\text { Process energy } \\
\text { savings (Q/yr) }\end{array}$ \\
\hline Sulfuric acid & 99.20 & 99.5 & 840 & 0.0006 \\
\hline Ammonia & 87.12 & 99 & 8000 & 0.0425 \\
\hline Propylene & 95.00 & 95 & 7500 & 0.0089 \\
\hline Nitric acid & 94.05 & 95 & 1120 & 0.0011 \\
\hline Ethylene dichloride & 94.05 & 99 & 1700 & 0.0017 \\
\hline Vinyl chloride & 93.10 & 98 & 7500 & 0.0074 \\
\hline Benzene & N/A & N/A & 1000 & \\
\hline Ethylbenzene & 98.01 & 99 & 600 & 0.0001 \\
\hline MTBE & 99.00 & 100 & 5600 & 0.0006 \\
\hline Styrene & 90.00 & 90 & 5500 & 0.0055 \\
\hline Methanol & 98.01 & 99 & 4250 & 0.0008 \\
\hline Formaldehyde & 91.00 & 91 & 0 & 0.0000 \\
\hline Xylene & N/A & N/A & 4400 & \\
\hline Toluene & N/A & N/A & 4400 & \\
\hline p-Xylene & 70.00 & 70 & 9600 & 0.0233 \\
\hline Terephthalic acid & 85.50 & 90 & 5500 & 0.0053 \\
\hline Ethylene oxide & 76.00 & 80 & 170 & 0.0003 \\
\hline Ethylene glycol & 98.01 & 99 & 5600 & 0.0006 \\
\hline Cumene & 97.02 & 99 & 1025 & 0.0001 \\
\hline Phenol & 97.00 & 97 & 6500 & 0.0007 \\
\hline Acetic acid & 99.00 & 99 & 4600 & 0.0002 \\
\hline Butadiene & 67.50 & 90 & 22000 & 0.0337 \\
\hline Acrylonitrile & 66.50 & 66.5 & 2600 & 0.0037 \\
\hline Propylene 0xide & 90.00 & 90 & 7000 & 0.0021 \\
\hline Vinyl acetate & 90.00 & 90 & 6650 & 0.0020 \\
\hline Acetone & 88.20 & 90 & 5630 & 0.0018 \\
\hline Cyclohexane & 99.80 & 100 & 340 & 0.0000 \\
\hline Adipic acid & 90.00 & 90 & 12500 & 0.0024 \\
\hline Caprolactam & 90.25 & 95 & 3400 & 0.0005 \\
\hline Isobutylene & 98.01 & 99 & & 0.0000 \\
\hline Total & & & & 0.1459 \\
\hline
\end{tabular}




\subsubsection{Feedstock Energy Saved from Improving Overall Yields}

When fewer feedstocks are needed to sustain a desired product production level, the required feedstock energy is reduced. The calculated savings in feedstock energy summed over all 30 catalytically produced chemicals equals $0.2380 \mathrm{Q} / \mathrm{yr}$ (see Table 2).

Table 2. Feedstock Energy Savings from Overall Yield Improvements

\begin{tabular}{|l|c|c|c|c|}
\hline \multicolumn{1}{|c|}{ Chemical. } & Process yield & $\begin{array}{c}\text { Feedstock (F) } \\
\text { energy (Btu/lb) }\end{array}$ & $\begin{array}{c}\text { F energy w/o } \\
\text { double counting }\end{array}$ & $\begin{array}{c}\text { F energy } \\
\text { savings (Q/yr) }\end{array}$ \\
\hline Sulfuric acid & 99.20 & 0 & 0 & 0.0000 \\
\hline Ammonia & 87.12 & 10500 & 10500 & 0.0558 \\
\hline Propylene & 95.00 & 21000 & 21000 & 0.0250 \\
\hline Nitric acid & 94.05 & - & 0 & 0.0000 \\
\hline Ethylene dichloride & 94.05 & 7800 & 7800 & 0.0079 \\
\hline Vinyl chloride & 93.10 & - & 0 & 0.0000 \\
\hline Benzene & N/A & 18000 & 18000 & \\
\hline Ethylbenzene & 98.01 & 18000 & 18000 & 0.0040 \\
\hline MTBE & 99.00 & 21000 & 0 & 0.0000 \\
\hline Styrene & 90.00 & 18500 & 1481.85 & 0.0015 \\
\hline Methanol & 98.01 & 12200 & 12200 & 0.0022 \\
\hline Formaldehyde & 91.00 & 19000 & 8771.1 & 0.0061 \\
\hline Xylene & $\mathrm{N} / \mathrm{A}$ & 18500 & 18500 & \\
\hline Toluene & $\mathrm{N} / \mathrm{A}$ & 18250 & 18250 & \\
\hline p-Xylene & 70.00 & 18500 & 18500 & 0.0449 \\
\hline Terephthalic acid & 85.50 & 18500 & 0 & 0.0000 \\
\hline Ethylene oxide & 76.00 & 16000 & 16000 & 0.0281 \\
\hline Ethylene glycol & 98.01 & 9100 & 0 & 0.0000 \\
\hline Cumene & 97.02 & 20060 & 20060 & 0.0028 \\
\hline Phenol & 97.00 & 18700 & 3.74 & 0.0000 \\
\hline Acetic acid & 99.00 & 8300 & 0 & 0.0000 \\
\hline Butadiene & 67.50 & 24750 & 24750 & 0.0379 \\
\hline Acrylonitrile & 66.50 & 28000 & 13753.6 & 0.0196 \\
\hline Propylene oxide & 90.00 & 21000 & 1050 & 0.0003 \\
\hline Vinyl acetate & 90.00 & 12830 & 11.54 .7 & 0.0003 \\
\hline Acetone & 88.20 & 15800 & 1393.56 & 0.0004 \\
\hline Cyclohexane & 99.80 & 17100 & 17100 & 0.0001 \\
\hline Adipic acid & 90.00 & 16000 & 2216 & 0.0004 \\
\hline Caprolactam & 90.25 & 16000 & 2608 & 0.0004 \\
\hline Isobutylene & 98.01 & 12000 & 12000 & 0.0003 \\
\hline Total & & & & $\mathbf{0 . 2 3 8 0}$ \\
\hline
\end{tabular}




\subsubsection{Process Energy Saved from Improving Per-Pass Yields}

. Many processes involve multiple passes to achieve high overall process yields. A generic process may only achieve a fractional conversion in any single pass and must rely on downstream reactant separation and recycle to the reactor. The energy that is required from these multi-pass processes is much higher than those that produce saleable chemicals in a single pass. A new process energy (Btu/lb) is calculated to account for process yield improvements. Previously reported energy values (Lipinsky and Widrig, 1994) are multiplied by the maximum fractional improvement in process yield. Processes that do not require feedstocks above stoichiometric amounts will require less energy per pound to produce. These new process energy numbers are then used to calculate potential savings by assuming that non-unity per-pass conversions could be converted to a single-pass process (see Table 3). Improving the per-pass process efficiency would save $0.4482 \mathrm{Q} / \mathrm{yr}$. 
Table 3. Process Energy Savings from Per-Pass Yield Improvements

\begin{tabular}{|l|c|c|c|c|}
\hline \multicolumn{1}{|c|}{ Chemical } & $\begin{array}{c}\text { Per-pass } \\
\text { conversion }\end{array}$ & $\begin{array}{c}\text { Old process } \\
\text { energy (Btu/lb) }\end{array}$ & $\begin{array}{c}\text { New process } \\
\text { energy (Btu/lb) }\end{array}$ & $\begin{array}{c}\text { Process energy } \\
\text { savings }\end{array}$ \\
\hline Sulfuric acid & 99.70 & 840 & 833.24 & 0.0002 \\
\hline Ammonia & 20.0 & 8000 & 6817.26 & 0.1961 \\
\hline Propylene & 60.0 & 7500 & 7105.26 & 0.0642 \\
\hline Nitric acid & 99.0 & 1120 & 1049.14 & 0.0002 \\
\hline Ethylene dichloride & 95.0 & 1700 & 1592.45 & 0.0013 \\
\hline Vinyl chloride & 60.0 & 7500 & 6944.15 & 0.0367 \\
\hline Benzene & 90.0 & 1000 & - & - \\
\hline Ethylbenzene & 99.0 & 600 & 587.82 & 0.0001 \\
\hline MTBE & 99.0 & 5600 & 5543.43 & 0.0006 \\
\hline Styrene & 70.0 & 5500 & 4888.89 & 0.0131 \\
\hline Methanol & 7.0 & 4250 & 4163.71 & 0.0338 \\
\hline Formaldehyde & 99.0 & 0 & 0.00 & 0.0000 \\
\hline Xylene & 80.0 & 4400 & - & - \\
\hline Toluene & 90.0 & 4400 & - & - \\
\hline p-Xylene & 18.0 & 9600 & 5485.71 & 0.0255 \\
\hline Terephthalic acid & 90.0 & 5500 & 4567.25 & 0.0026 \\
\hline Etyylene oxide & 15.0 & 170 & 116.32 & 0.0005 \\
\hline Ethylene glycol & 99.0 & 5600 & 5486.30 & 0.0003 \\
\hline Cumene & 91.0 & 1025 & 993.52 & 0.0004 \\
\hline Phenol & 50.0 & 6500 & 6298.97 & 0.0117 \\
\hline Acetic acid & 90.0 & 4600 & 4553.54 & 0.0016 \\
\hline Butadiene & 75.0 & 22000 & 11407.41 & 0.0091 \\
\hline Acrylonitrile & 95.0 & 2600 & 1290.23 & 0.0002 \\
\hline Propylene oxide & 22.0 & 7000 & 6222.22 & 0.0131 \\
\hline Vinyl acetate & 15.0 & 6650 & 5911.11 & 0.0134 \\
\hline Acetone & 50.0 & 5630 & 4876.78 & 0.0058 \\
\hline Cyclohexane & 99.0 & 340 & 339.32 & 0.0000 \\
\hline Adipic acid & 10.0 & 12500 & 11111.11 & 0.0175 \\
\hline Caprolactam & 95.0 & 3400 & 3032.69 & 0.0002 \\
\hline Isobutylene & 99.0 & & 0.00 & 0.0000 \\
\hline Total & & & & 0.4482 \\
\hline
\end{tabular}


A total energy savings of $0.8320 \mathrm{Q} / \mathrm{yr}$ could be realized by improving both the overall and per-pass process efficiencies (see Table 4). These numbers were calculated in the attached spreadsheet (top50proc_calc.xls).

Table 4. Total Energy Savings

\begin{tabular}{|l|c|c|c|c|}
\hline \multicolumn{1}{|c|}{ Chemical } & $\begin{array}{c}\text { Process Energy } \\
\text { savings-1c }\end{array}$ & $\begin{array}{c}\text { Feedstock } \\
\text { Energy savings }\end{array}$ & $\begin{array}{c}\text { Process Energy } \\
\text { savings-2 }\end{array}$ & $\begin{array}{c}\text { Sum of Energy } \\
\text { savings }\end{array}$ \\
\hline Sulfuric acid & 0.0006 & 0.0000 & 0.0002 & 0.0008 \\
\hline Ammonia & 0.0425 & 0.0558 & 0.1961 & 0.2944 \\
\hline Propylene & 0.0089 & 0.0250 & 0.0642 & 0.0981 \\
\hline Nitric acid & 0.0011 & 0.0000 & 0.0002 & 0.0013 \\
\hline Ethylene dichloride & 0.0017 & 0.0079 & 0.0013 & 0.0108 \\
\hline Vinyl chloride & 0.0074 & 0.0000 & 0.0367 & 0.0441 \\
\hline Benzene & - & - & - & 0.0000 \\
\hline Ethylbenzene & 0.0001 & 0.0040 & 0.0001 & 0.0042 \\
\hline MTBE & 0.0006 & 0.0000 & 0.0006 & 0.0012 \\
\hline Styrene & 0.0055 & 0.0015 & 0.0131 & 0.0200 \\
\hline Methanol & 0.0008 & 0.0022 & 0.0338 & 0.0367 \\
\hline Formaldehyde & 0.0000 & 0.0061 & 0.0000 & 0.0061 \\
\hline Xylene & - & - & - & 0.0000 \\
\hline Toluene & - & - & - & 0.0000 \\
\hline p-Xylene & 0.0233 & 0.0449 & 0.0255 & 0.0936 \\
\hline Terephthalic acid & 0.0053 & 0.0000 & 0.0026 & 0.0078 \\
\hline Ethylene oxide & 0.0003 & 0.0281 & 0.0005 & 0.0289 \\
\hline Ethylene glycol & 0.0006 & 0.0000 & 0.0003 & 0.0009 \\
\hline Cumene & 0.0001 & 0.0028 & 0.0004 & 0.0034 \\
\hline Phenol & 0.0007 & 0.0000 & 0.0117 & 0.0124 \\
\hline Acetic acid & 0.0002 & 0.0000 & 0.0016 & 0.0018 \\
\hline Butadiene & 0.0337 & 0.0379 & 0.0091 & 0.0806 \\
\hline Acrylonitrile & 0.0037 & 0.0196 & 0.0002 & 0.0235 \\
\hline Propylene oxide & 0.0021 & 0.0003 & 0.0131 & 0.0155 \\
\hline Vinyl acetate & 0.0020 & 0.0003 & 0.0134 & 0.0157 \\
\hline Acetone & 0.0018 & 0.0004 & 0.0058 & 0.0081 \\
\hline Cyclohexane & 0.0000 & 0.0001 & 0.0000 & 0.0001 \\
\hline Adipic acid & 0.0024 & 0.0004 & 0.0175 & 0.0204 \\
\hline Caprolactam & 0.0005 & 0.0004 & 0.0002 & 0.0011 \\
\hline Isobutylene & 0.0000 & 0.0003 & 0.0000 & 0.0003 \\
\hline Total & & & & 0.8320 \\
\hline
\end{tabular}

c calculated from overall yield improvements.

d calculated from per pass yield improvements. 


\subsection{Environmental Impact}

The generation of carbonaceous products is often accompanied by the formation of carbon dioxide. In some processes it is produced directly; in others, unwanted carbonaceous byproducts are later incinerated or biologically converted. In either case, the cumulative effect exceeds 20.9 billion pounds of carbon dioxide released during the production of the top 50 chemicals (see Table 5). These numbers were calculated using the attached spreadsheet (top50proc_calc.xls).

Relative to the annual total carbon dioxide produced in the U.S. from fossil fuel sources, 2.75 trillion pounds (C \& EN News, March 13, 1989), production of the top 50 chemicals accounts for approximately $0.76 \%$ of the total annual carbon dioxide emissions in the United States. 
Table 5. Carbon Dioxide Production

\begin{tabular}{|c|c|c|c|c|c|}
\hline Chemical & Feedstock-1 & $\begin{array}{c}\mathrm{CO}_{2}-1 \\
\text { (bil-lb/yr) }\end{array}$ & Feedstock-2 & $\begin{array}{l}\mathrm{CO}_{2}-2 \\
\text { (bil-lb/yr) }\end{array}$ & $\begin{array}{l}\text { Total } \\
\mathrm{CO}_{2}\end{array}$ \\
\hline Sulfuric acid & $\mathrm{SO} 2$ & & & & \\
\hline Ammonia & methane & & & - & \\
\hline Propylene & propane & & & & \\
\hline Nitric acid & ammonia & & & & \\
\hline Ethylene dichloride & ethylene & 0.821 & chlorine & & 0.821 \\
\hline Vinyl chloride & ethylene dichloride & 1.381 & & & 1.381 \\
\hline Benzene & naphtha & & & & - \\
\hline Ethylbenzene & ethylene & .0 .092 & benzene & 0.556 & 0.648 \\
\hline MTBE & methanol & 0.096 & isobutylene & 0 & 0.096 \\
\hline Styrene & ethylbenzene & 2.298 & & & 2.298 \\
\hline Methanol & carbon monoxide & 0.213 & hydrogen & & 0.213 \\
\hline Formaldehyde & methanol & 1.080 & & & 1.080 \\
\hline Xylene & naphtha & & & & $=$ \\
\hline Toluene & naphtha & & & & - \\
\hline p-Xylene & xylenes & & & & - \\
\hline Terephthalic acid & p-xylene & 0.629 & & & 0.629 \\
\hline Ethylene oxide & ethylene & 3.512 & & & 3.512 \\
\hline Ethylene glycol & ethylene oxide & 0.082 & & & 0.082 \\
\hline Cumene & benzene & 0.000 & propylene & 0.000 & \\
\hline Phenol & cumene & 0.483 & & & 0.483 \\
\hline Acetic acid & methanol & 0.027 & $\begin{array}{c}\text { carbon } \\
\text { monoxide }\end{array}$ & $0.323^{\circ}$ & 0.350 \\
\hline Butadiene & butene & 4.990 & & & 4.990 \\
\hline Acrylonitrile & propylene & 1.629 & ammonia & & 1.629 \\
\hline Propylene oxide & propylene & 0.683 & iso-butane & 0.910 & 1.593 \\
\hline Vinyl acetate & ethylene & 0.302 & acetic acid & 0.000 & 0.302 \\
\hline Acetone & cumene & & & & \\
\hline Cyclohexane & benzene & 0.014 & hydrogen & & 0.014 \\
\hline Adipic acid & cyclohexane & 0.352 & nitric acid & & 0.352 \\
\hline Caprolactam & cyclohexane & 0.348 & & & 0.348 \\
\hline Isobutylene & n-butane & 0.082 & & & 0.082 \\
\hline Total & & & & & 20.903 \\
\hline
\end{tabular}

\subsection{Economic Impact}

The extra feedstock required to compensate for process inefficiencies results in economic losses. The wasted moles of feedstock were calculated and assigned dollar values from Chemical Marketing Reporter. Summed over all of the top catalytically produced chemicals, over two billion dollars is used to purchase feedstocks that are 
eventually converted to carbon dioxide. These numbers were calculated in the attached spreadsheet (top50proc_ref.xls).

Table 6. Economic Impact

\begin{tabular}{|c|c|c|c|c|c|c|c|c|}
\hline Chemical & $\begin{array}{l}\text { Feedstock-1 } \\
\text { (F-1) }\end{array}$ & $\begin{array}{c}\mathrm{F}-1 \\
\text { (bil } \\
\mathrm{lb} / \mathrm{yr})\end{array}$ & $\begin{array}{c}\mathrm{F}-1 \\
\text { cost } \\
(\$ / 1 \mathrm{~b}) \\
\end{array}$ & $\begin{array}{c}\text { F-1 } \\
\text { wasted } \\
\text { (bil \$) } \\
\end{array}$ & $\begin{array}{l}\text { Feedstock-2 } \\
\text { (F-2) }\end{array}$ & $\begin{array}{c}\text { F-2 } \\
\text { (bil } \\
\text { lb/yr) }\end{array}$ & $\begin{array}{c}F-2 \\
\text { cost } \\
(\$ / 1 b)\end{array}$ & $\begin{array}{c}\text { F-2 } \\
\text { wasted } \\
\text { (bil \$) }\end{array}$ \\
\hline Sulfuric acid & $\mathrm{SO}_{2}$ & 0.467 & 0.115 & 0.054 & & & & \\
\hline Ammonia & methane & 0.625 & & & & & & \\
\hline Propylene & propane & 0 & & & & & & \\
\hline Nitric acid & ammonia & 0.275 & 0.130 & 0.036 & & & & \\
\hline $\begin{array}{l}\text { Ethylene } \\
\text { dichloride }\end{array}$ & ethylene & 0.261 & 0.280 & 0.073 & chlorine & & & \\
\hline Vinyl chloride & $\begin{array}{l}\text { ethylene } \\
\text { dichloride }\end{array}$ & 1.553 & 0.170 & 0.264 & & & & \\
\hline Benzene & naphtha & & 0.148 & & & & & \\
\hline Ethylbenzene & ethylene & 0.029 & 0.280 & 0.008 & benzene & 0.164 & 0.143 & 0.023 \\
\hline MTBE & methanol & 0.096 & 0.068 & 0.007 & i-butylene & 0 & 0.310 & \\
\hline Styrene & ethylbenzene & 0.692 & 0.270 & 0.187 & & & & \\
\hline Methanol & $\begin{array}{l}\text { carbon } \\
\text { monoxide }\end{array}$ & 0.155 & & & hydrogen & & & \\
\hline Formaldehyde & methanol & 0.736 & 0.068 & 0.050 & & & & \\
\hline Xylene & naphtha & & 0.148 & & & & & \\
\hline Toluene & naphtha & & 0.148 & & & & & \\
\hline p-Xylene & xylenes & 0.841 & 0.159 & 0.134 & & & & \\
\hline $\begin{array}{l}\text { Terephthalic } \\
\text { acid }\end{array}$ & p-xylene & 0.190 & 0.360 & 0.068 & & & & \\
\hline Ethylene oxide & ethylene & 1.117 & 0.280 & 0.313 & & & & \\
\hline $\begin{array}{l}\text { Ethylene } \\
\text { glycol }\end{array}$ & ethylene oxide & 0.041 & 0.450 & 0.018 & & & & \\
\hline Cumene & benzene & 0 & 0.143 & & propylene & 0 & 0.223 & \\
\hline Phenol & cumene & 0.146 & 0.200 & 0.029 & & & & \\
\hline Acetic acid & methanol & 0.027 & 0.068 & 0.002 & $\begin{array}{l}\text { carbon } \\
\text { monoxide }\end{array}$ & 0.206 & & \\
\hline Butadiene & butene & 1.588 & 0.260 & 0.413 & & & & \\
\hline Acrylonitrile & propylene & 0.654 & 0.223 & 0.146 & ammonia & & & \\
\hline $\begin{array}{l}\text { Propylene } \\
\text { oxide }\end{array}$ & propylene & 0.217 & 0.223 & 0.048 & iso-butane & 0.300 & & \\
\hline Vinyl acetate & ethylene & 0.096 & 0.280 & 0.027 & acetic acid & 0 & 0.330 & \\
\hline Acetone & cumene & & 0.200 & & & & & \\
\hline Cyclohexane & benzene & 0.004 & 0.143 & 0.001 & hydrogen & & & \\
\hline Adipic acid & cyclohexane & 0.112 & 0.181 & 0.020 & nitric acid & & & \\
\hline Caprolactam & cyclohexanone & 0.129 & 0.730 & 0.094 & & & & \\
\hline Isobutylene & n-butane & 0.027 & 0.260 & 0.007 & & & & \\
\hline Total & & & & & & & & 2.022 \\
\hline
\end{tabular}




\subsection{Process Limitations}

The production routes of the catalytically produced top 50 chemicals have eight key process limitations, categorized as follows:

- $\operatorname{Lim} 1=$ Equilibrium-limited (main reaction)

- $\operatorname{Lim} 2=$ Equilibrium-limited (competitive reactions)

- $\operatorname{Lim} 3=$ Kinetics-limited (main reaction)

- $\operatorname{Lim} 4=$ Kinetics-limited (competing reactions)

- $\operatorname{Lim} 5=$ Catalyst deactivation

- $\operatorname{Lim} 6=$ Heat addition limited

- $\operatorname{Lim} 7=$ Heat removal limited

- $\operatorname{Lim} 8=$ Mass transfer limited

The potential energy savings from each chemical have been cross-referenced against the process limitation(s) (see Table 7).

Those processes affected by more than one limitation were not assigned fractional impact values. The total possible energy savings was inserted in each category. The sums of each category were normalized to determine a relative importance of the various process limitations. Three categories account for approximately three-quarters of all limitations: equilibrium limitations for the main reaction, kinetic limitations for the main reaction, and kinetic limitations resulting from competing reactions. 
Table 7. Process Limitations

\begin{tabular}{|l|l|l|l|l|l|l|l|l|}
\hline \multicolumn{1}{|c|}{ Chemical } & Lim-1 & Lim-2 & Lim-3 & Lim-4 & Lim-5 & Lim-6 & Lim-7 & Lim-8 \\
\hline Sulfuric acid & & 0.0008 & & & & & & \\
\hline Ammonia & 0.2944 & & 0.2944 & & & & & \\
\hline Propylene & & & & 0.0981 & & & & \\
\hline Nitric acid & 0.0013 & & & & & & & \\
\hline $\begin{array}{l}\text { Ethylene } \\
\text { dichloride }\end{array}$ & & & & 0.0108 & & & & \\
\hline Vinyl chloride & & & & 0.0441 & & & 0.0441 & \\
\hline Benzene & & & & & & & & \\
\hline Ethylbenzene & & 0.0042 & & 0.0042 & & & & \\
\hline MTBE & 0.0012 & & & & & & 0.0012 & 0.0012 \\
\hline Styrene & & & & & & 0.0200 & & 0.0200 \\
\hline Methanol & 0.0367 & & 0.0367 & & & & & \\
\hline Formaldehyde & 0.0061 & & & 0.0061 & & & & \\
\hline Xylene & & & & & & & & \\
\hline Toluene & & & & & & & & \\
\hline p-Xylene & & 0.0936 & & & & & & \\
\hline $\begin{array}{l}\text { Terephthalic } \\
\text { acid }\end{array}$ & & & 0.0078 & 0.0078 & & & & \\
\hline Ethylene oxide & & & & 0.0289 & 0.0289 & & 0.0289 & \\
\hline Ethylene glycol & & & & & & & & \\
\hline Cumene & & & & 0.0034 & & & & \\
\hline Phenol & & & & 0.0124 & & & & \\
\hline Acetic acid & & 0.0018 & & 0.0018 & & & & \\
\hline Butadiene & & & & 0.0806 & 0.0806 & & 0.0806 & \\
\hline Acrylonitrile & & & & 0.0235 & & & & \\
\hline Propylene oxide & & & & 0.0155 & & & & \\
\hline Vinyl acetate & & & & 0.0157 & & & 0.0157 & 0.0157 \\
\hline Acetone & & & & 0.0081 & & & & \\
\hline Cyclohexane & & & & & & & 0.0001 & \\
\hline Adipic acid & & & & 0.0204 & & & 0.0204 & \\
\hline Caprolactam & & & & 0.0011 & & & & \\
\hline Isobutylene & & & & 0.0003 & 0.0003 & 0.0003 & & \\
\hline Normalized \% & 22.34 & 6.61 & 22.30 & 25.19 & 7.23 & 1.34 & $\mathbf{1 2 . 5 7}$ & 2.43 \\
\hline
\end{tabular}




\subsection{Impact on Top 12 Polymers}

Many of the commodity chemicals are precursors for polymer products. A study to describe the top 12 polymer production processes and the associated energy consumption is under preparation (Lipinsky and Wesson, 1995). Table 8 presents the percentage of each commodity chemical used as a polymer feedstock, the total excess process and feedstock energy, the value of wasted feedstock, and the amount of carbon dioxide that is generated producing commodity chemicals that later become the top 12 polymers. This information is included in the attached spreadsheet (top50proc_calc.xls).

An excess of $0.2734 \mathrm{Q} / \mathrm{yr}$ is needed to produce the polymer precursor chemicals. This represents nearly one-third of the total extra energy required for the top 50 commodity chemicals. Approximately 1 billion dollars are wasted to purchase excess feedstocks. This equates to nearly one-half of the total dollar value wasted to produce all of the commodity chemicals. Over 7.8 billion pounds of carbon dioxide are co-produced with the polymer precursor chemicals; this represents approximately $38 \%$ of the total. 
Table 8. Impact of Commodity Chemicals on Top 12 Polymers

\begin{tabular}{|c|c|c|c|c|}
\hline Chemical & $\begin{array}{c}\% \text { used to } \\
\text { produce top } 12 \\
\text { polymers }\end{array}$ & $\begin{array}{c}\text { Total energy } \\
\text { savings } \\
(\mathrm{Q} / \mathrm{yr})\end{array}$ & $\begin{array}{c}\text { Wasted } \\
\text { feedstock } \\
\text { (bil \$) }\end{array}$ & $\begin{array}{l}\text { CO2 generated } \\
\text { (bil lb/yr) }\end{array}$ \\
\hline \multicolumn{5}{|l|}{ Sulfuric acid } \\
\hline \multicolumn{5}{|l|}{ Ammonia } \\
\hline Propylene & 46 & 0.0451 & 0.0000 & \\
\hline Nitric acid & 10 & 0.0001 & 0.0036 & . \\
\hline Ethylene dichloride & 88 & 0.0095 & 0.0643 & 0.7225 \\
\hline Vinyl chloride & 84 & 0.0370 & 0.2218 & 1.1600 \\
\hline Benzene & 64 & & . & \\
\hline \multicolumn{5}{|l|}{ Ethylbenzene } \\
\hline \multicolumn{5}{|l|}{ MTBE } \\
\hline Styrene & 77 & 0.0154 & 0.1439 & 1.7695 \\
\hline Methanol & 27 & 0.0099 & 0.0000 & 0.0575 \\
\hline Formaldehyde & 29 & 0.0018 & 0.0146 & 0.3132 \\
\hline \multicolumn{5}{|l|}{ Xylene } \\
\hline Toluene & 4 & & . & \\
\hline p-Xylene & 100 & 0.0936 & 0.1337 & \\
\hline Terephthalic acid & 99 & 0.0078 & 0.0677 & 0.6227 \\
\hline Ethylene oxide & 28 & 0.0081 & 0.0876 & 0.9834 \\
\hline Ethylene glycol & 29 & 0.0003 & 0.0054 & 0.0238 \\
\hline Cumene & 63 & 0.0021 & 0.0000 & \\
\hline Phenol & 54 & 0.0067 & 0.0158 & 0.2608 \\
\hline Acetic acid & . & & & \\
\hline Butadiene & 16 & 0.0129 & 0.0660 & 0.7984 \\
\hline Acrylonitrile & 18 & 0.0042 & 0.0262 & 0.2932 \\
\hline Propylene oxide & 17 & 0.0026 & 0.0082 & 0.2708 \\
\hline \multicolumn{5}{|l|}{ Vinyl acetate } \\
\hline \multicolumn{5}{|l|}{ Acetone } \\
\hline Cyclohexane & 82 & 0.0000 & 0.0005 & 0.0115 \\
\hline Adipic acid & 74 & 0.0151 & 0.0150 & 0.2605 \\
\hline Caprolactam & 87 & 0.0010 & 0.0819 & 0.3028 \\
\hline \multicolumn{5}{|l|}{ Isobutylene } \\
\hline Total & & 0.2734 & 0.9560 & 7.8505 \\
\hline$\%$ of top 50 total & & 32.86 & 47.29 & 37.56 \\
\hline
\end{tabular}




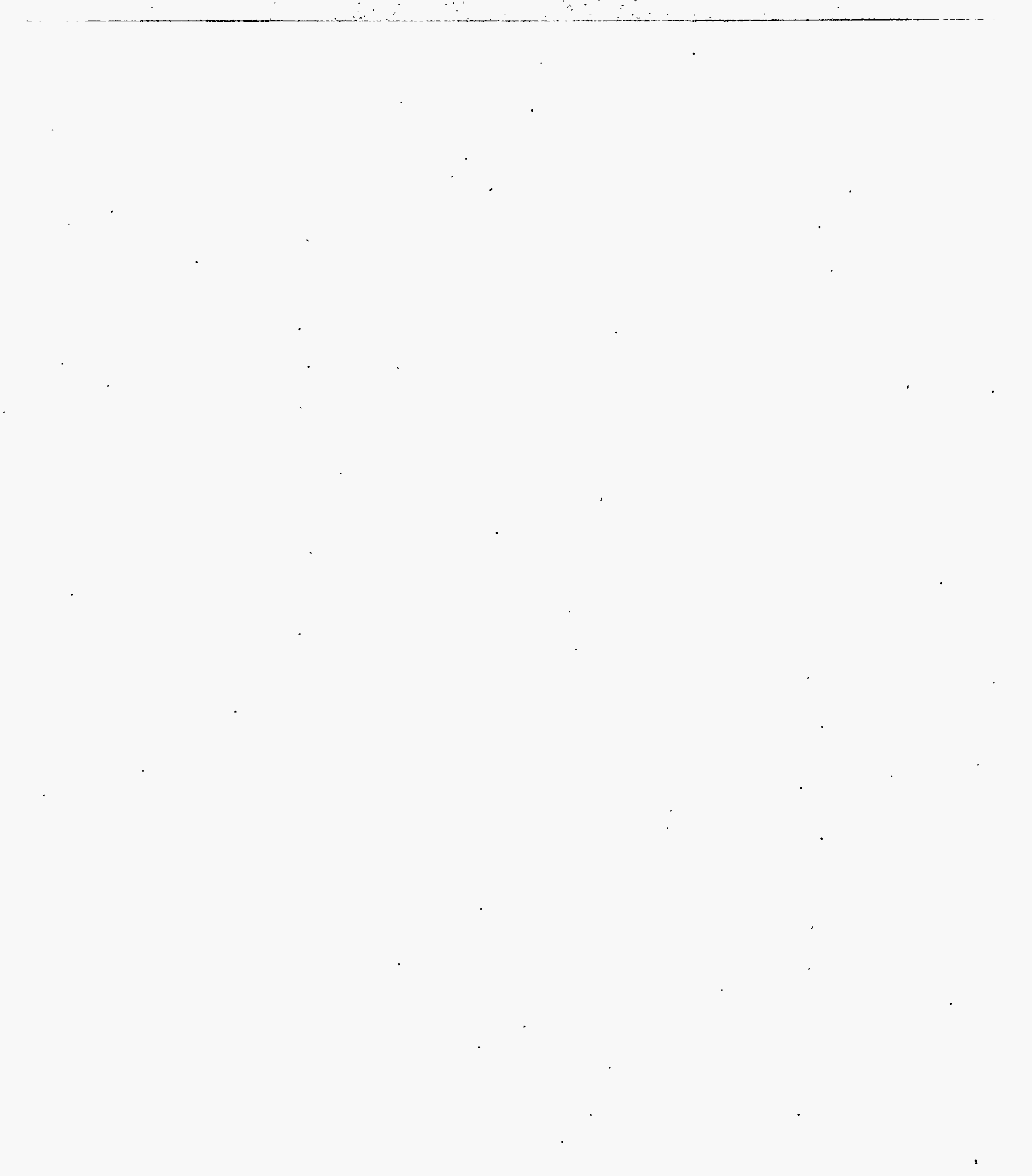




\subsection{Advanced Process Concepts}

The process improvements needed to achieve the energy savings assumed in this study represent, in many cases, dramatic changes to existing processes. Realization of these improvements will not occur through incremental improvements in catalysts or process design. The complex underlying problems are not intractable, but they do require new approaches that address the interdependent problems and process limitations.

A strategy to integrate catalysis design and development with reactor design is proposed to achieve these goals. Most of the process inefficiencies result from kinetic, thermodynamic, and transport limitations. In general, catalysis can address kinetic limitations, while reactor design addresses thermodynamic and transport limitations. For complex problems, both approaches must be integrated.

\subsection{Catalysis Design and Development}

Catalysis plays a direct role in the production of 30 of the top 50 commodity chemicals, and an indirect one for six other chemicals. Catalyst improvements have a direct impact in lowering production temperatures, increasing per-pass yields, and decreasing unwanted byproducts.

Catalysis alone, however, will not maximize process efficiency. All reactions progress along the lowest energy pathway toward thermodynamic equilibrium, although many reactions are operated far from equilibrium and are controlled by competing reaction rates. The addition of a catalyst increases reaction rates but cannot change the thermodynamic driving force that provides the direction for the reaction. If for a given set of conditions, an equilibrium yield of only $30 \%$ were possible, then the addition of a catalyst would allow the reactor to achieve a $30 \%$ yield in less time.

For many chemicals, it is thermodynamics that limits process efficiency. The production of ammonia is one example where the conversion is dictated by thermodynamics. At the current processing temperatures and pressures, conversions range between $10 \%$ and $30 \%$ per pass. Higher per-pass yields are possible by changing pressure, temperature, or composition but not by improving the catalyst. 


\subsection{Reactor Design}

The selection of an appropriate reactor design is equally important in developing a catalytic reactor. Issues of heat and mass transport are addressed through reactor design and are vital to the efficiency and safety of the production processes. Many of the commodity chemical production routes are highly exothermic. The problems arising from inefficient heat removal and mass transport range from undesirable product distributions to thermal runaway and potential explosions.

Reactor design, in conjunction with appropriate catalyst selection, can overcome adverse thermodynamic constraints. Equilibrium is defined for a static system based on temperature, pressure, and composition. For a flowing system, the local values of these parameters set reaction driving forces. Novel reactor designs that alter in situ temperature, pressure, or composition change local driving forces. The result is a reactor that appears to "beat" equilibrium. This concept has been put into practice for the production of MTBE ( 24 billion lb/yr).

MTBE is produced through reactive distillation, and yields approach $99 \%$ per pass. The product is simultaneously removed via distillation as the reaction proceeds, pushing the reaction further toward completion. Yields of this magnitude are only possible with an appropriate reactor design that couples separation and reaction.

For the case of ammonia, a reactor design that separates ammonia as it is produced could achieve higher per-pass yields than those observed commercially. Local reductions in the ammonia partial pressure add a forward driving force that would push this reaction toward completion.

Redesigned reactors include, but are not.limited to, the generic class of separative reactors. This emerging field represents a suite of enabling technologies that have the potential to improve the production yields for many reactions. These include ammonia, styrene, ethylene oxide, propylene oxide, methanol, butadiene, hydrogen, and many others.

True process efficiency gains for the commodity chemicals will best be achieved through the integration of catalysis and an appropriate reactor design. Each alone will not maximize process efficiency gains, but developed in concert the limitations from both kinetics and thermodynamics can be overcome. 


\subsection{Integrated Process Design}

This section describes the problems associated with the top 50 production processes and possible advanced process concepts to mitigate those issues. The process limitations cited for the production routes of the 30 catalytically produced chemicals are divided into the following concepts:

- Concept 1: Thermodynamic Limitations on Per-Pass Conversion

Problem: The production of several chemicals, including ammonia, methanol, and styrene, has a limited conversion per pass dictated by thermodynamics. The operating temperature, pressure, and feed composition result in low yields per pass. This situation leads to an added reactant and product separation unit operation, followed closely by a reactant recycle loop. The energy required to heat, cool, separate, and recycle feedstocks makes these processes energy-intensive.

Potential solution: Product separation during reaction increases the . thermodynamic driving force and allows the reaction to continue toward completion. The coupling of reaction and separation requires melding two unit operations into one to exploit process synergy. The requisite operating conditions (temperature, pressure, and chemical environment) must be matched to successfully join these operations. In addition, the separation medium must remain catalytically inert to the reactants. Several successful examples of this concept have been described in the literature, and one successful commercial operation (reactive-distillation) is in use for the production of MTBE.

The types of separative reactors include, but are not limited to, reactivedistillation, membrane reactors, pressure-swing adsorbers/reactors, and chromatographic reactors. 


\section{Concept 1}

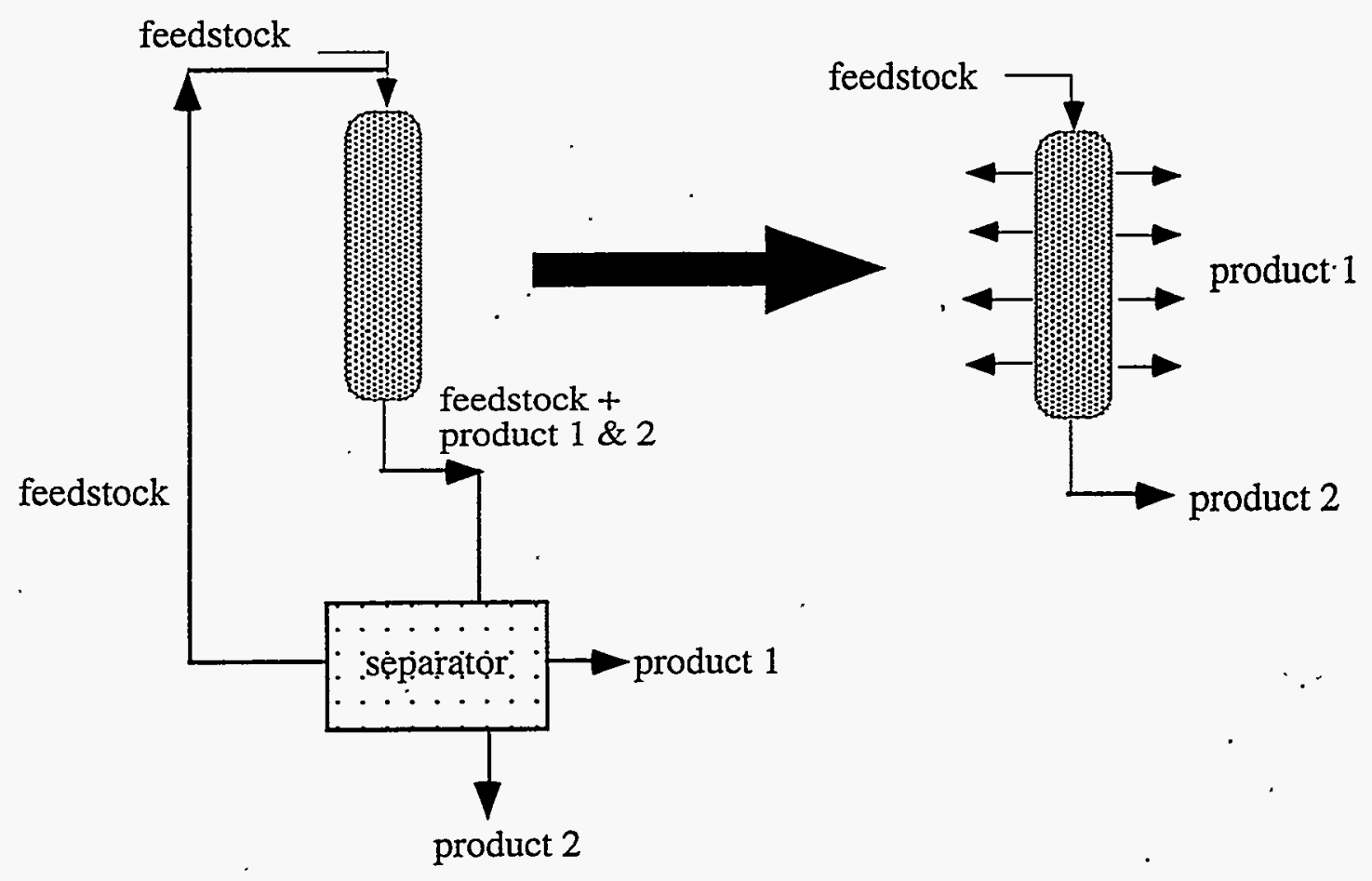


- Concept 2: Kinetic Limitations - Low Catalyst Activity

Problem: The production of several chemicals, including ammonia and methanol, has a low process efficiency because of kinetic constraints. The activity of the catalysts is fairly low, or the reaction conditions must be kept modest to prevent undesired side reactions.

Potential solution: More active catalysts would result in shorter contact times, smaller reactor volumes, and increased process efficiency.

\section{Concept 2.}
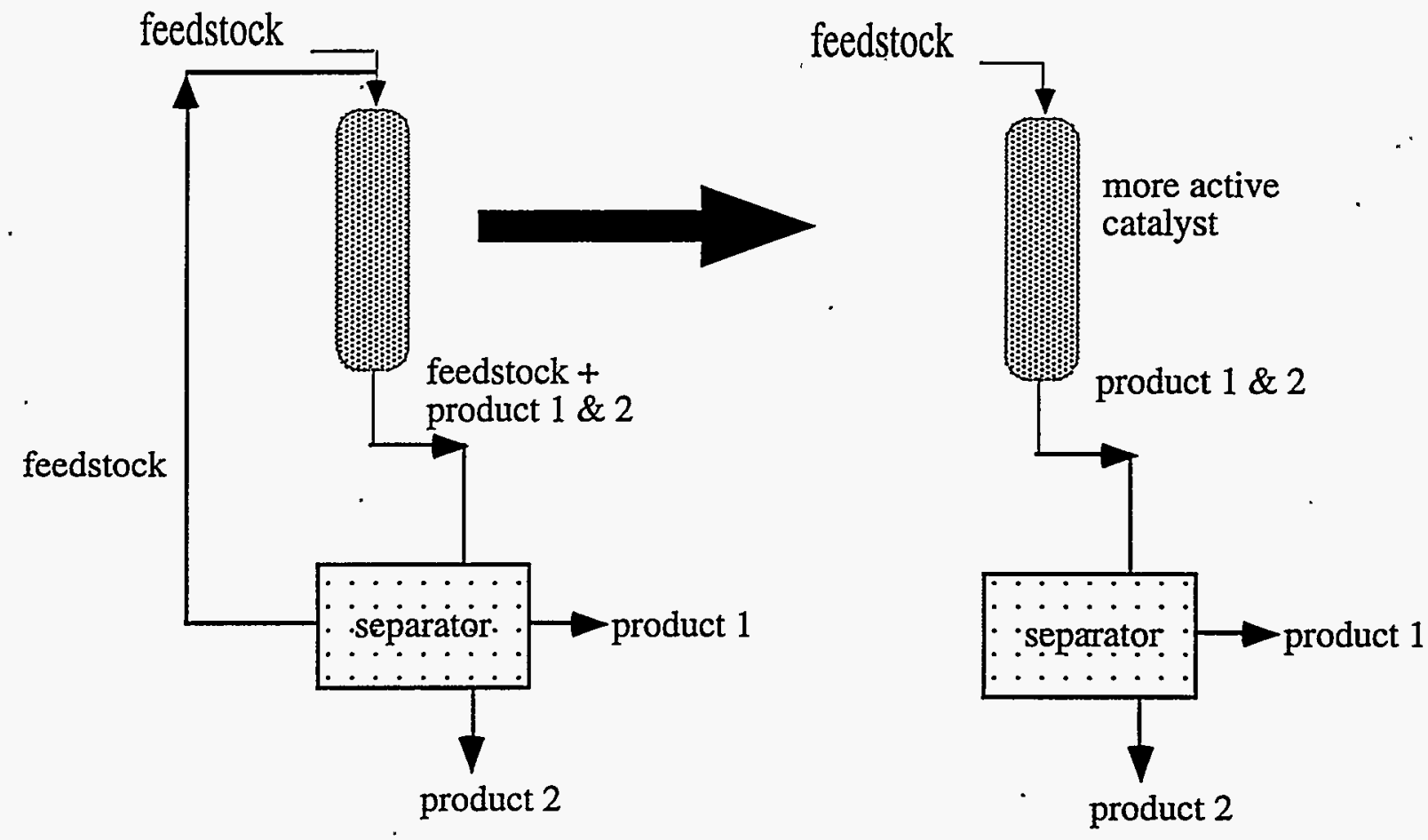
- Concept 3: Kinetic Limitations - Low Catalyst Selectivity

Problem: The production of several chemicals, including ethylene oxide, butadiene, and acrylonitrile, has a low process efficiency because of kinetic constraints. The selectivity of the catalysts is low and undesired side reactions result in the generation of no-value byproducts.

Potential solution: More selective catalysts would result in a decrease in the generation of byproducts and increase process efficiency.

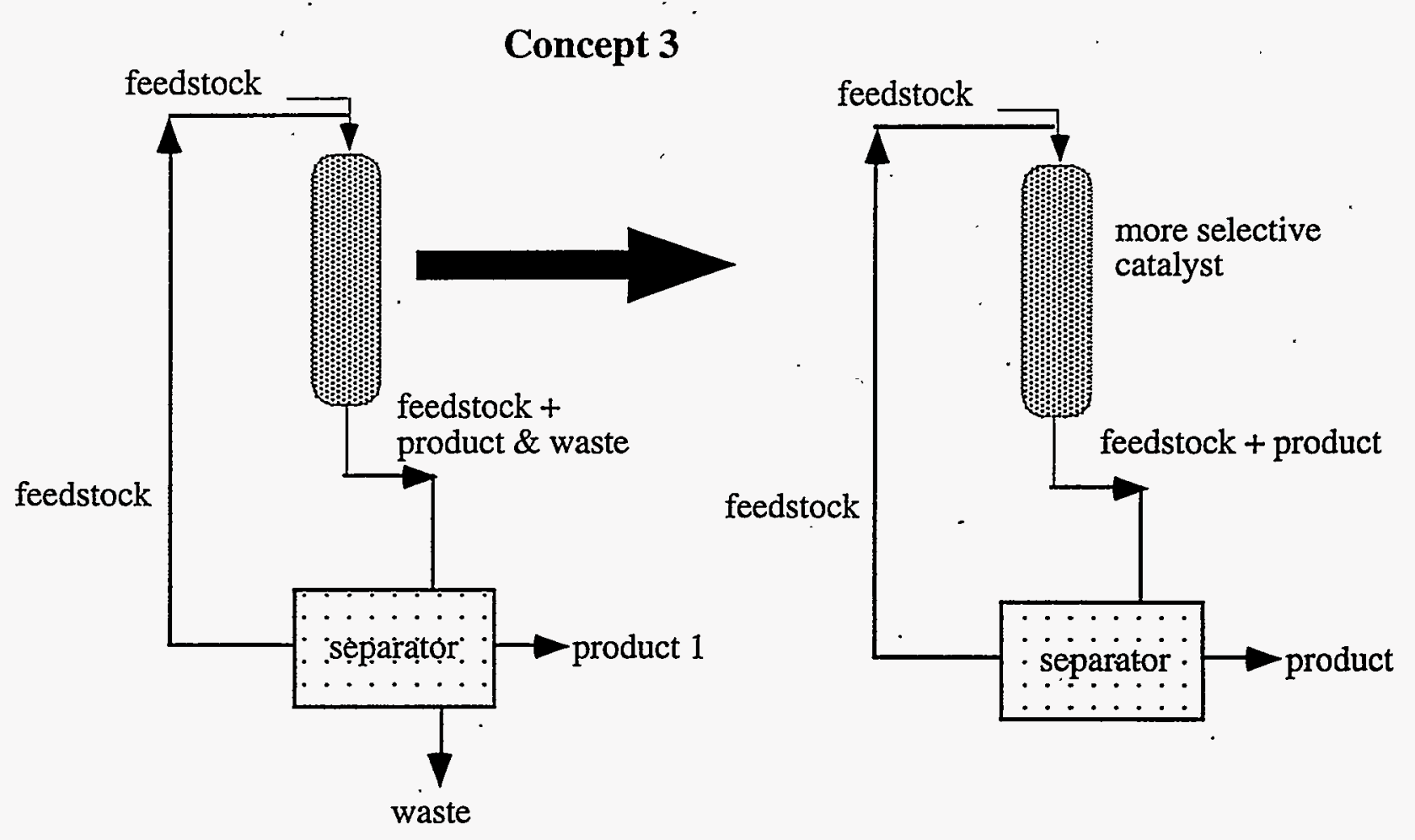


- Concept 4: Coupled Kinetic and Thermodynamic Limitations

Problem: The production of several chemicals, including ethylene oxide, propylene oxide, and formaldehyde, has a low process efficiency because of coupled kinetic and thermodynamic constraints. The desired products are more reactive than the feedstock and rapidly overoxidize to carbon dioxide. In addition, there is a strong thermodynamic driving force to produce carbon oxides, rather than the desired intermediate product.

Potential solution: More selective catalysts would decrease the generation of byproducts and increase process efficiency. However, catalyst development can not mitigate the thermodynamic driving force to overoxidize the product. This advanced concept controls the oxygen addition to favor the desired reactions by changing the local oxygen partial pressures that dictate thermodynamic driving forces.

\section{Concept 4}

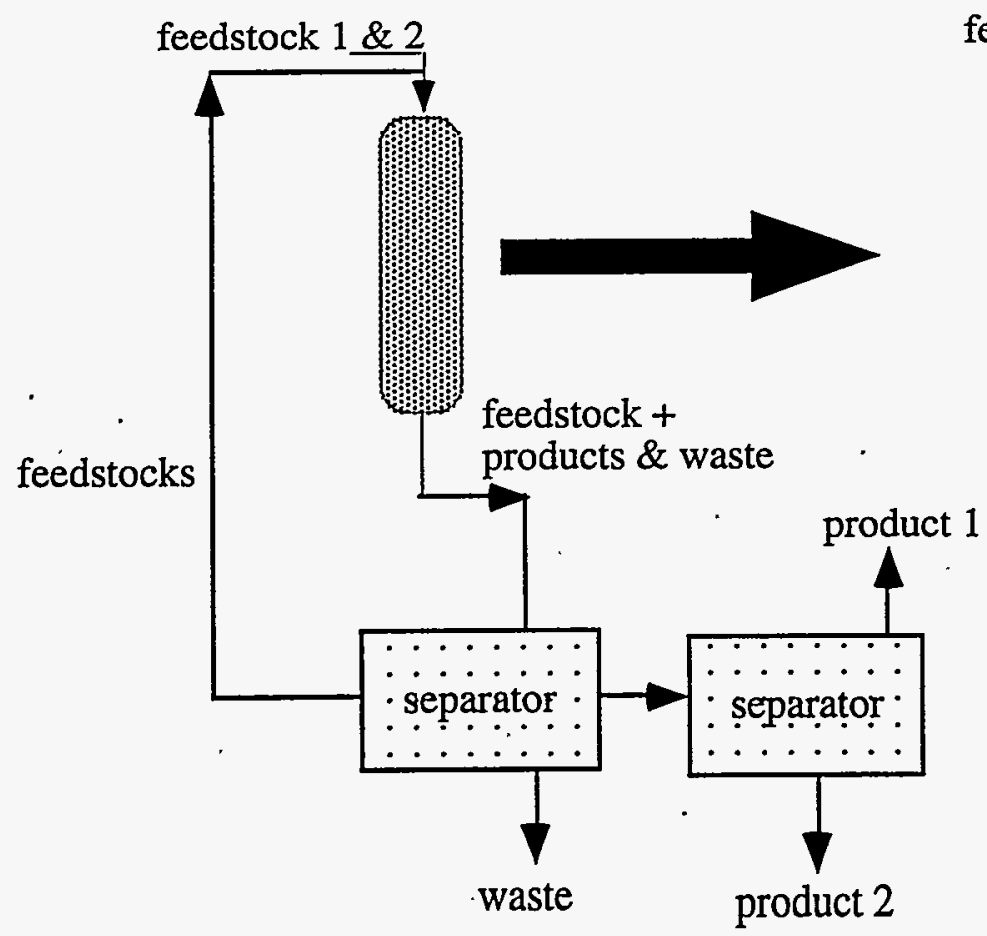

feedstock 1

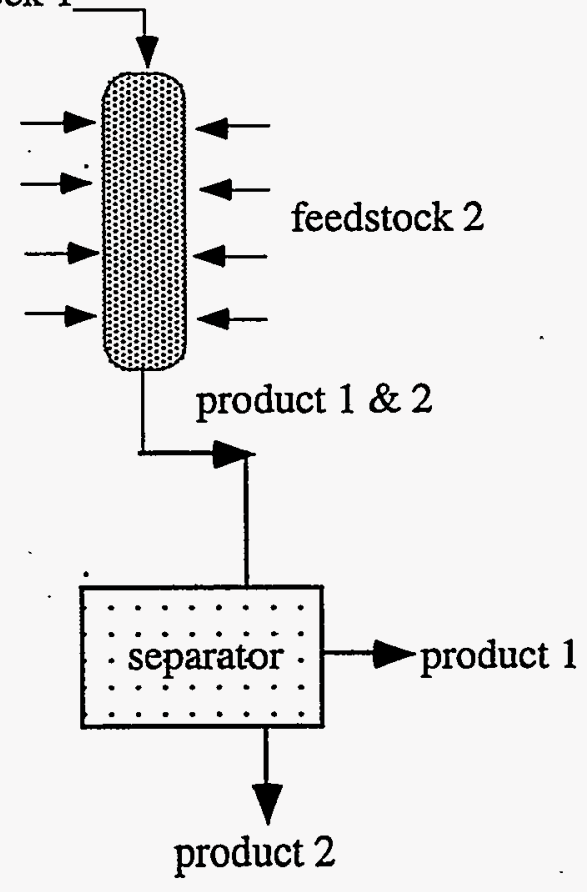


- Concept 5: Transport Limitations

Problem: The production of several chemicals, including ethylene oxide and adipic acid, has a low process efficiency because of transport limitations. The highly exothermic reactions generate heat at a faster rate than it can be removed with conventional methods. To counter this problem, a diluent is often added to the feed to reduce the heat generated per unit volume. As a result the process must heat, transport, and cool excess material that in some cases represents. a volume exceeding 10 times that of the feedstocks.

Potential solution: Improved heat removal technologies would reduce or eliminate the amount of diluent needed to ensure safe operation of the reactor. Higher production rates per unit volume would increase the process efficiency.

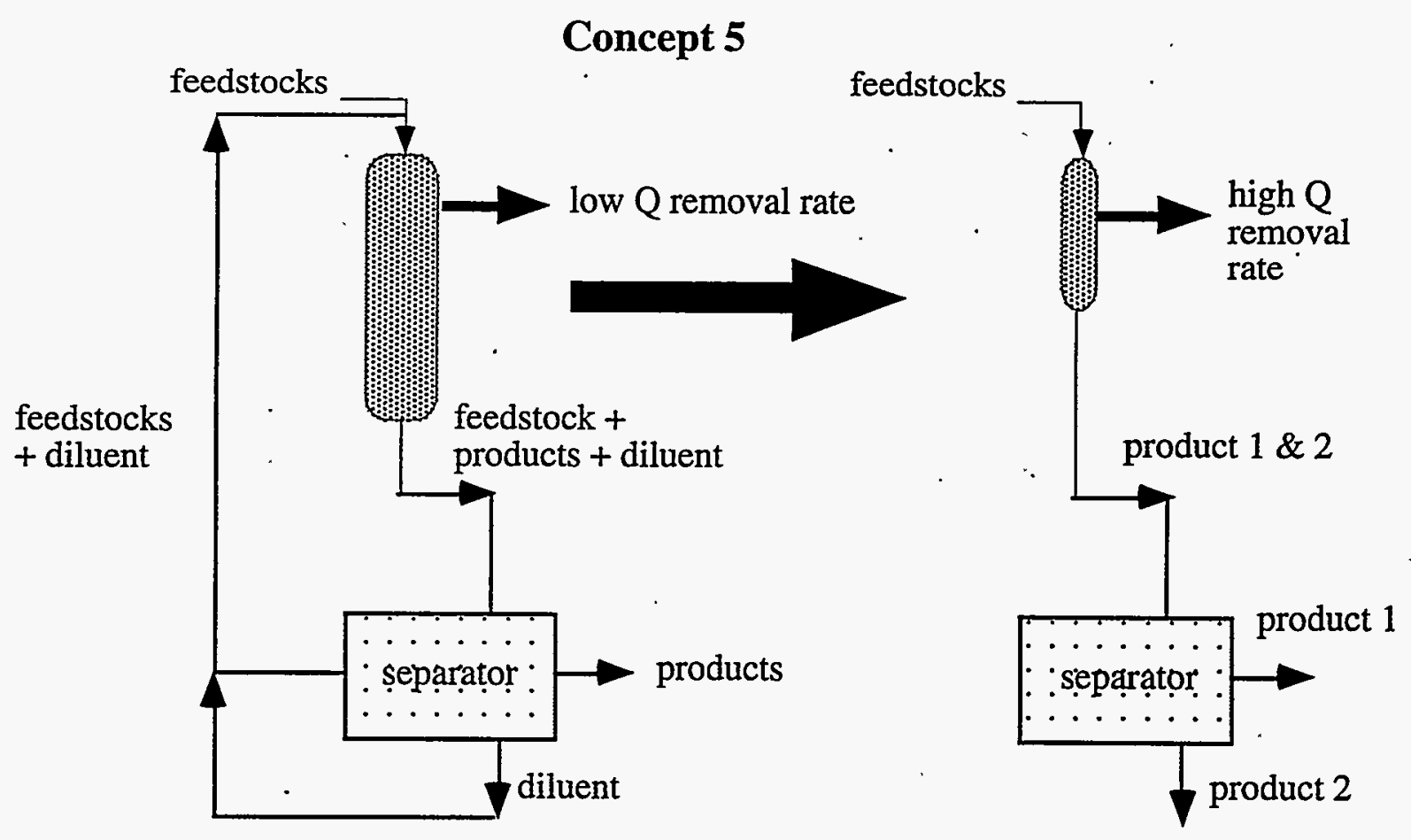


- Concept 6: Transport, Kinetic, and Thermodynamic Limitations

Problem: The production of several chemicals, including ethylene oxide and adipic acid, has a low process efficiency because of coupled transport, kinetic, and thermodynamic limitations. The conversions per pass are maintained at a low level to safely operate the reactor with a high product selectivity.

Potential solution: New technologies that simultaneously mitigate all three limitations are required to improve the process efficiency. Improved heat transfer coupled with new catalysts and reactor designs to mitigate the process limitations is required.

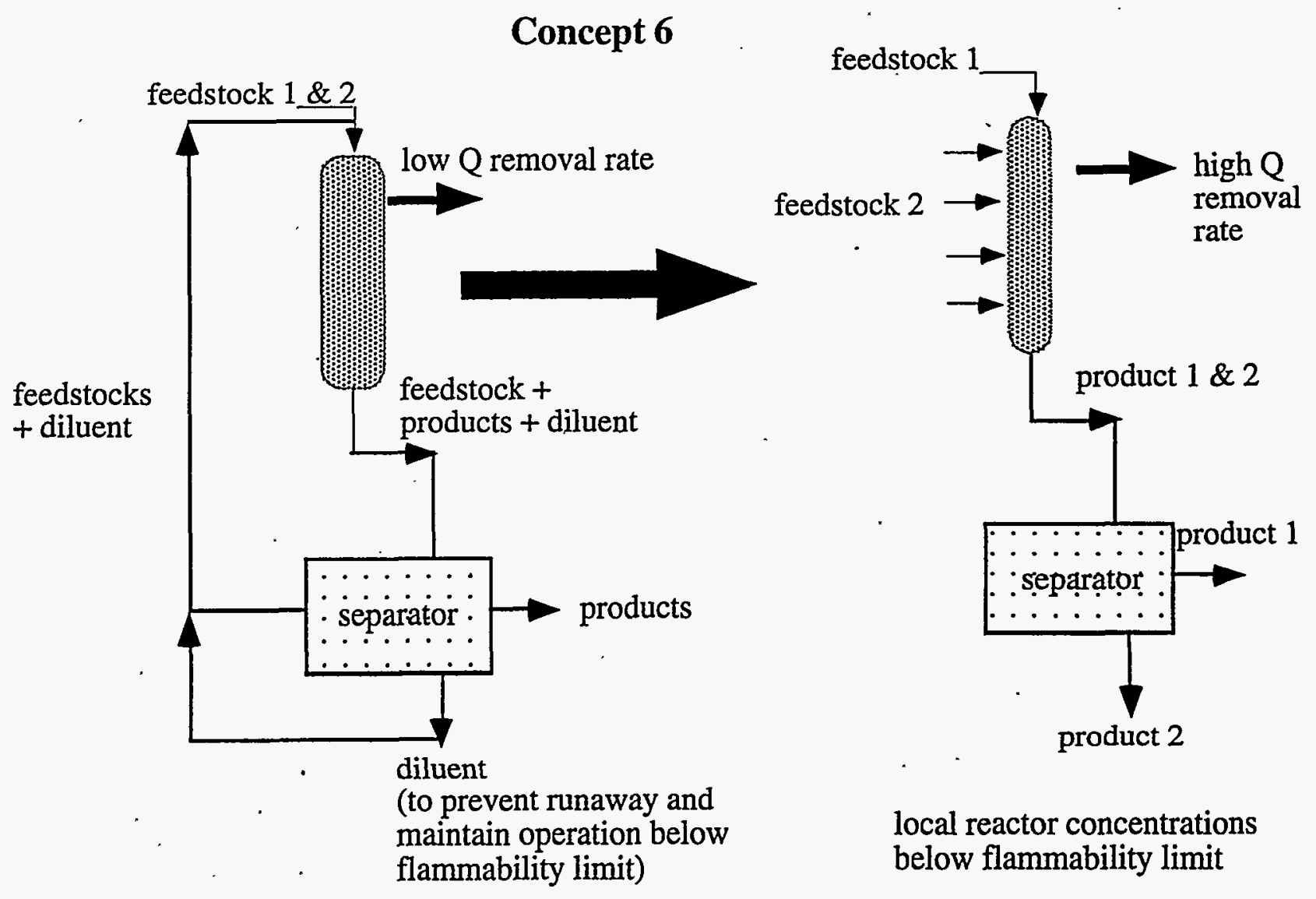




\subsection{Conclusions}

The production routes associated with the catalytically produced commodity chemicals consume additional energy and raw materials beyond those necessary to produce the desired level of saleable products. In this study waste is quantified in terms of energy, environment, and economics. It was found that 0.83 quads of energy are wasted, 20.9 billion pounds of carbon dioxide are released to the atmosphere, and over 2 billion dollars are spent to purchase feedstocks that are converted to waste.

The process inefficiencies that give rise to this waste are a function of both kinetics and thermodynamics. Traditional approaches to overcoming these limitations, namely catalyst development, are an important component to the solution. Alone, however, catalyst selection will not overcome many of the problems. Integration of catalyst development and reactor design is necessary to counter the process limitations and reduce the associated energy, environmental, and economic burdens. 


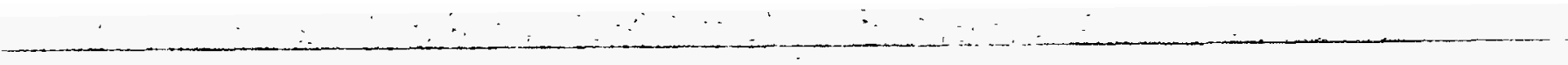




\subsection{References and Bibliography}

Buchner, W., R. Schliebs, G. Winter, and K. H. Buchel, 1989, Industrial Organic Chemistry, Trans. by D. R. Terrell. VCH Publishers, New York.

C\&EN News, March 13, 1989, Global warming, 67(11), 41.

Chemical Marketing Reporter, May 8, 1995.

Chenier, P. J., 1986, Survey of Industrial Chemistry, John Wiley \& Sons, New York.

Considine, D., 1974, Chemical and Process Technology Encyclopedia, McGraw-Hill Book Company.

Fahey, D. R., Ed., 1987, Industrial Chemicals via C1 Processes, American Chemical Society, New York.

Hatch, L., and S. Matar, 1981, From Hydrocarbons to Petrochemicals, Gulf Publishing Company.

Kirk Othmer, 1984, Encyclopedia of Chemical Technology, 3rd ed., and 4th ed. Vol. 19.

Leach, B. E., 1983, Applied Industrial Catalysis, Vol. 1., Academic Press, NY.

Lipinsky, E., and J. Widrig, 1994, Draft Task Report: Brief Characterization of the Top 50 U. S. Commodity Chemicals, Battelle, Pacific Northwest laboratory, Columbus, Ohio.

Lipinsky, E., and R. Wesson, 1995, Draft Task Report: Characterizations of the Top 12 U.S. Commodity Polymers, Battelle, Pacific Northwest laboratory, Columbus, Ohio.

Lowenheim, F., and M. Moran, 1975, Industrial Chemicals, Wiley-Interscience Publishers.

Mark, H. F., N. M Bikales, C. G. Overberger, and G. Menges, eds., 1985-1990, Encyclopedia of Polymer Science and Engineering.

McKetta, J. J., ed., 1976-1995, Encyclopedia of Chemical Processing and Design, Marcel Dekker, Inc., New York.

Pearce, R., and W. R. Patterson, 1981, Catalysis and Chemical Processes, John Wiley and Sons, New York.

"Petrochemical Handbook '95", 1995, Hydrocarbon Processing, 74(3) 89-149.

Satterfield, C. N. 1991, Heterogeneous Catalysis in Industrial Practice, 2nd ed. McGrawHill, Inc., New York.

Sittig, M., 1968, Alcohols, Polyols and Phenols Manufacture and Derivatives, Noyes Development Corporation, Park Ridge, New Jersey. 
Slack, A. V. and G. R. James, eds., 1973, Ammonia, Parts 1 and 3. Vol. 2 of Fertilizer Science and Technology Series, Marcel Dèkker, Inc., New York.

"Sources and Production Economics of Chemical Products", 1979, edited by Chemical Engineering, McGraw-Hill Publications Co.

Tonkovich, A. L. Y., 1994, Impact of Catalysis on the Production of the Top 50 U. S. Commodity Chemicals, PNL-9432, Pacific Northwest Laboratory, Richland, Washington. 


\section{APPENDIX I}

Potential Feedstock and Process Energy Savings Calculations

(attached file: top50proc_calc.xls) 


\begin{tabular}{|c|c|c|c|c|c|c|c|}
\hline Chemical & $\begin{array}{c}\text { lb (bil) } \\
\mathbf{9 2} \\
\end{array}$ & $\begin{array}{c}\text { Overall } \\
\text { process } \\
\text { yield }\end{array}$ & $\begin{array}{c}\text { Conversion } \\
\text { per Pass }\end{array}$ & Selectivity & $\begin{array}{c}\text { Per pass } \\
\text { yield }\end{array}$ & $\begin{array}{c}\text { Maximum } E \\
\text { savings from } \\
\text { overall process } \\
\text { improvements } \\
(\mathrm{P}+\mathrm{F})-1994 \\
\text { study }\end{array}$ & $\begin{array}{l}\text { Maximum E savings } \\
\text { from per pass yield } \\
\text { improvements and } \\
\text { overall process yield } \\
\text { improvements }\end{array}$ \\
\hline Sulfuric acid & 88.8 & 99.2015 & 99.7 & 99.5 & 99.2015 & 0.0006 & 0.0008 \\
\hline Nitrogen & $\begin{array}{r}58.7 \\
\end{array}$ & & & & & & \\
\hline \begin{tabular}{|l|} 
Oxygen \\
Ethylene
\end{tabular} & $\begin{array}{r}42.38 \\
40.41\end{array}$ & & 1 & & & & 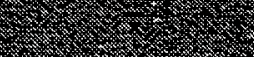 \\
\hline \begin{tabular}{|l} 
Elnylene \\
Ammonia
\end{tabular} & 35.95 & 87.12 & 20 & 99 & 19.8 & 0.0857 & 0.2944 \\
\hline Lime & 34.72 & & & & & & \\
\hline Phosphoric acid & 25.36 & & & & & & \\
\hline Sodium hydroxide & 24.02 & & & & & $x_{1}$ & \\
\hline Propylene & 22.6 & 95 & 60 & 95 & 57 & 0.0322 & 0.0981 \\
\hline Chlorine & 22.28 & 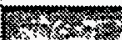 & & & & & \\
\hline Sodium carbonate & 20.89 & & & & & & \\
\hline Urea & 16.84 & & & & & & \\
\hline Nitric acid & 16.08 & 94.05 & 99 & 95 & 94.05 & 0.0011 & 0.0013 \\
\hline Ethylene dichloride & 15.94 & 94.05 & 95 & 99 & 94.05 & 0.0090 & 0.0108 \\
\hline Ammonium nitrate & 15.33 & 20 & $x$ & 18 & 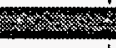 & 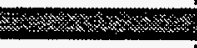 & \\
\hline Vinyl chloride & 13.23 & 93.1 & 60 & 98 & 58.8 & 0.0069 & 0.0441 \\
\hline Benzene & 12.01 & N/A & 90 & N/A & $\mathrm{N} / \mathrm{A}$ & 0.0639 & 0.0000 \\
\hline Ethylbenzene & 10.99 & 98.01 & 99 & 99 & 98.01 & 0.0001 & 0.0042 \\
\hline MTBE & 10.86 & 99 & 99 & 100 & 99 & 0.0006 & 0.0012 \\
\hline Carbon dioxide & 10.79 & & & & 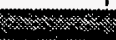 & & \\
\hline Styrene & 8.94 & 90 & 70 & 90 & 63 & 0.0396 & 0.0200 \\
\hline Methanol & 8.73 & 98.01 & 7 & 99 & 6.93 & 0.0029 & 0.0367 \\
\hline Formaldehyde & 6.98 & 91 & 99 & 91 & 90.09 & 0.0005 & 0.0061 \\
\hline Xylene & 6.38 & N/A & 80 & N/A & N/A & 0.0409 & 0.0000 \\
\hline Toluene & 6.03 & N/A & 90 & N/A & N/A & 0.0393 & 0.0000 \\
\hline Hydrochloric acid & 5.75 & & 8 & - & 8 & $88 \times$ & mas. \\
\hline p-Xylene & 5.66 & 70 & 18 & 70 & 12.6 & 0.0470 & 0.0936 \\
\hline Terephthalic acid & 5.64 & 85.5 & 90 & 90 & 81 & 0.0032 & 0.0078 \\
\hline Ethylene oxide & 5.56 & 76 & 15 & 80 & 12 & 0.0216 & 0.0289 \\
\hline Ethylene glycol & 5.12 & 98.01 & 99 & 99 & 98.01 & 0.0006 & 0.0009 \\
\hline Ammonium sulfate & 4.72 & 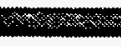 & & & & & \\
\hline Cumene & 4.57 & 97.02 & 91 & 99 & 90.09 & 0.0001 & 0.0034 \\
\hline Potash & 3.76 & 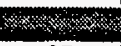 & 48 & 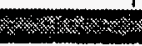 & 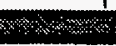 & & \\
\hline Phenol & 3.71 & 97 & 50 & 97 & 48.5 & 0.0036 & 0.0124 \\
\hline Acetic acid & 3.6 & 99 & 90 & 99 & 89.1 & 0.0021 & 0.0018 \\
\hline Butadiene & 3.18 & 67.5 & 75 & 90 & 67.5 & 0.0510 & 0.0806 \\
\hline Carbon black & 3.02 & 8 & & & $w$ & 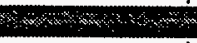 & \\
\hline Acrylonitrile & 2.83 & 66.5 & 95 & 66.5 & 63.175 & 0.0122 & 0.0235 \\
\hline Propylene oxide & 2.7 & 90 & 22 & 90 & 19.8 & 0.0022 & 0.0155 \\
\hline Vinyl acetate & 2.66 & 90 & 15 & 90 & 13.5 & 0.0018 & 0.0157 \\
\hline Titanium dioxide & 2.53 & & & & & & \\
\hline Acetone & 2.39 & 88.2 & 50 & 90 & 45 & 0.0020 & 0.0081 \\
\hline Cyclohexane & 2.21 & 99.8 & 99 & 100 & 99 & 0.0000 & 0.0001 \\
\hline Aluminum sulfate & 2.18 & & & & & $6+8$ & \\
\hline Sodium silicate & 1.8 & & & & & & \\
\hline Adipic acid & 1.75 & 90 & 10 & 90 & 9 & 0.0025 & 0.0204 \\
\hline Calcium chloride & 1.39 & & & & & \%: & \\
\hline Caprolactam & 1.38 & 90.25 & 95 & 95 & 90.25 & 0.0006 & $0.00 \mathrm{II}$ \\
\hline Sodium sulfate & 1.34 & & & & & & \\
\hline Isobutylene & 1.29 & 98.01 & 99 & 99 & 98.01 & 0.0003 & 0.0003 \\
\hline Sum & 655.98 & & & & & 0.4740 & 0.8320 \\
\hline & & & & & & & \\
\hline normalized fraction & & & & & & & \\
\hline$\%$ & & & & & & & \\
\hline & & & & & & & \\
\hline
\end{tabular}




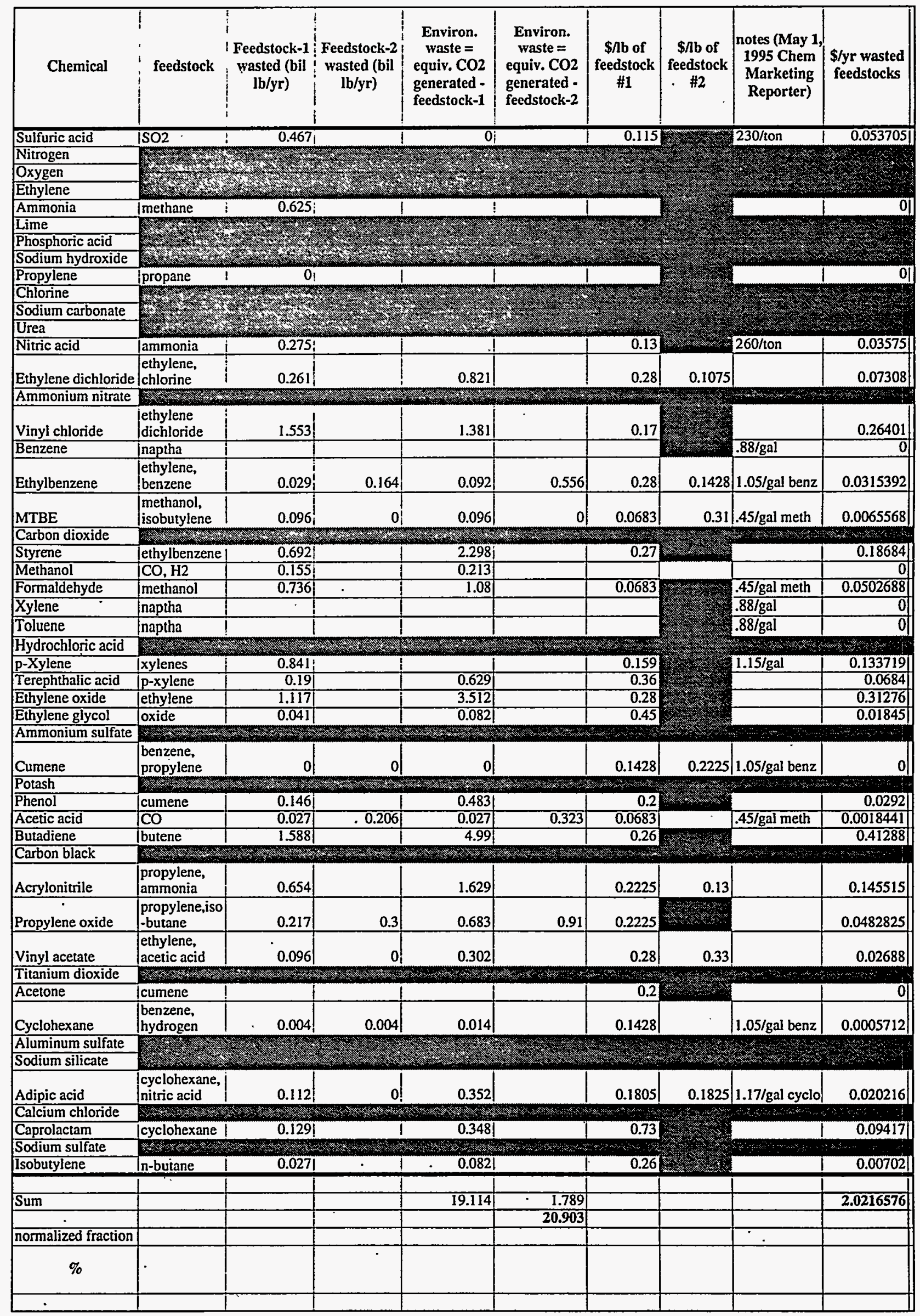




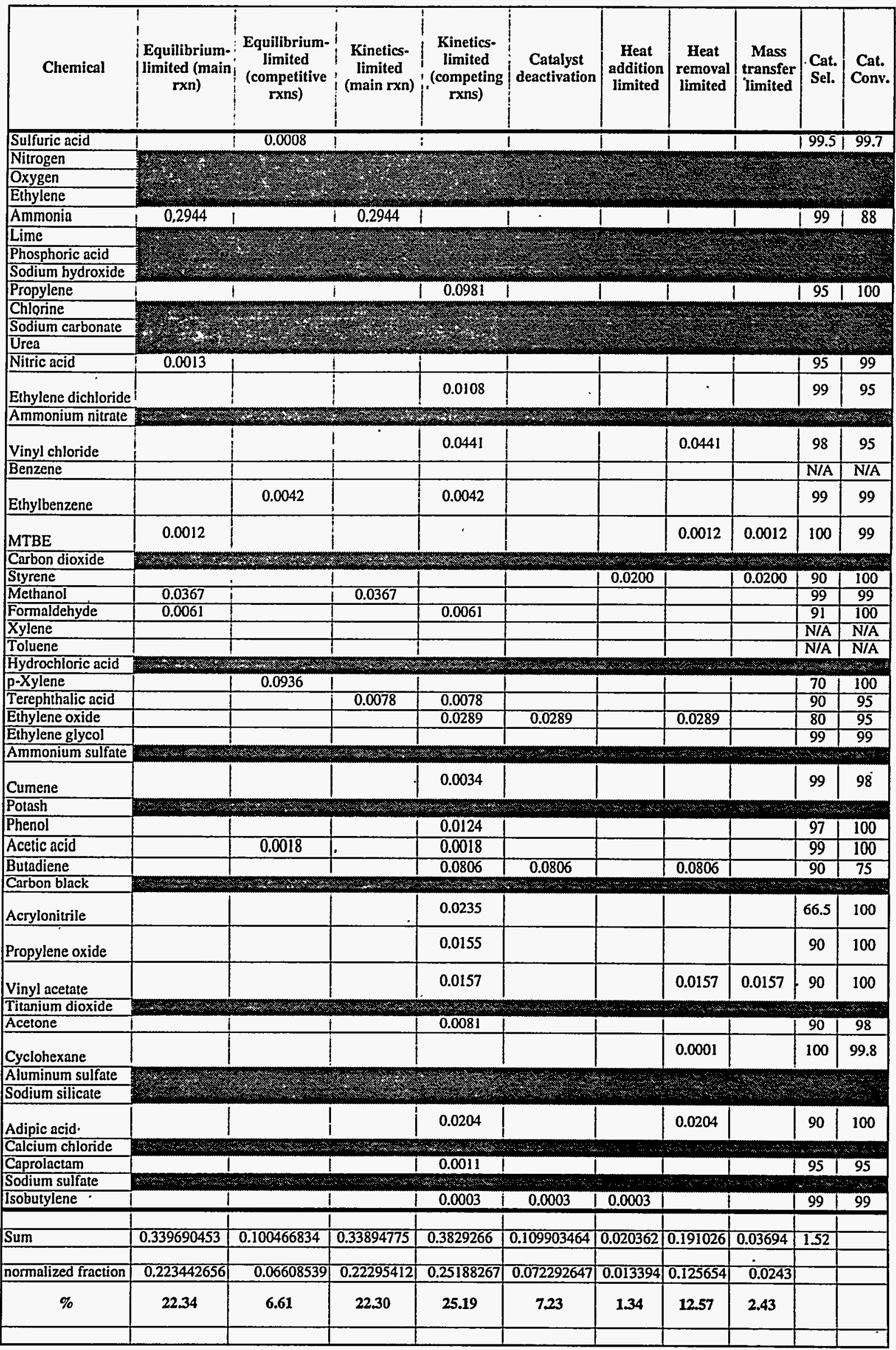




\begin{tabular}{|c|c|c|c|c|c|c|c|c|c|c|c|}
\hline Chemical & $\begin{array}{l}\text { Process } \\
\text { energy } \\
\text { (Btu/h) }\end{array}$ & $\begin{array}{l}\text { feedstock } \\
\text { energy } \\
\text { (Btu } A \mathrm{~b})\end{array}$ & \begin{tabular}{|c|}
$x$ s feedstock \\
energy \\
(avoids \\
double \\
counting) \\
Btu/hb
\end{tabular} & $\begin{array}{c}\text { feedstock } \\
\text { energy (w/o } \\
\text { double } \\
\text { counting) } \\
\text { Btulb }\end{array}$ & \begin{tabular}{|} 
fractional \\
savings from \\
overall process \\
improvement
\end{tabular} & $\begin{array}{l}\text { Btu savings in } \\
\text { process energy } \\
\text { from overall } \\
\text { improvement }\end{array}$ & $\begin{array}{c}\text { Btu savings in } \\
\text { feedstock } \\
\text { energy from } \\
\text { overall } \\
\text { improvement }\end{array}$ & $\begin{array}{c}\text { New process } \\
\text { energy for } \\
\text { yield eflicient } \\
\text { process } \\
(\mathrm{Btu} / \mathrm{b})\end{array}$ & $\begin{array}{c}\text { New } \\
\text { process Ex } \\
\text { production } \\
\text { rate }(Q / y r)\end{array}$ & \begin{tabular}{|} 
Process E \\
saved from \\
improving \\
YPP $(Q / y r)$
\end{tabular} & $\begin{array}{c}\text { Sum of wasted } \\
\text { energy from } \\
\text { process } \\
\text { inemiciencies and } \\
\text { extra feedstock } \\
\text { use (Q/yr) }\end{array}$ \\
\hline Sulfuric acid & 840 & & 이 & 0 & 0.0080 & 0.0006 & 0.0000 & 833.24 & 0.0740 & 0.0002 & 0.0 \\
\hline \begin{tabular}{|l|} 
Nitrogen \\
Oxygen \\
Ethylene \\
\end{tabular} & +2 & & & & $1 \times$ & 2 & $\sqrt{2}$ & 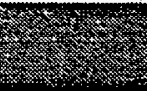 & 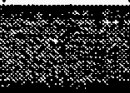 & 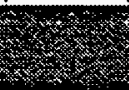 & \\
\hline Ammonia & 8000 & 10500 & $0 ;$ & 10500 & 0.1478 & 0.0425 & 0.0558 & 6817.26 & 0.2451 & 0.1961 & 0.2944 \\
\hline \begin{tabular}{|l|} 
Lime \\
Phosphoric acid \\
Sodium hydroxide \\
\end{tabular} & & & & & & & & 72 & & & \\
\hline \begin{tabular}{|l|} 
Propylene \\
Chlorine \\
Sodium carbonate \\
Urea
\end{tabular} & 7500 & 21000 & 01 & 21000 & 0.0526 & 0.0089 & 0.0250 & 7105.26 & 0.1606 & 0.0642 & 0.09 \\
\hline Nitric acid & 1120 & & 0 & 0 & 0.0633 & 0.0011 & 0.0000 & 1049.14 & 0.0169 & 0.0002 & 0.0013 \\
\hline \begin{tabular}{|l} 
Ethylene dichloride \\
Ammonium nitrate
\end{tabular} & 1700 & 7800 & 0 & 7800 & 0.0633 & 0.0017 & 0.0079 & 1592.45 & 0.0254 & 0.0013 & 0.0 \\
\hline Vinyl chloride & 7500 & & 0 & 0 & 0.0741 & 0.0074 & 0.0000 & 6944.15 & $\begin{array}{l}0.0919 \\
\end{array}$ & 0.0367 & \\
\hline Benzene & 1000 & 18000 & 0 & 18000 & $8+12$ & - & 28 & $3 \times 8 \times 8$ & $48 \%$ & $48 * 8 \times$ & 0.0000 \\
\hline Ethylbenzene & 600 & 18000 & 0 & 18000 & 0.0203 & 0.0001 & 0.0040 & 587.82 & 0.0065 & 0.0001 & 0.0042 \\
\hline MTBE & 5600 & 21000 & 21000 & 0 & 0.0101 & 0.0006 & 0.0000 & 5543.43 & 0.0602 & 0.0006 & 0.0012 \\
\hline \begin{tabular}{|l} 
Carbon dioxide \\
Styrene
\end{tabular} & & & & & & & & & & & \\
\hline \begin{tabular}{|l|} 
Styrene \\
Methanol \\
\end{tabular} & $\begin{array}{l}5500 \\
4250\end{array}$ & $\begin{array}{l}18500 \\
12200\end{array}$ & $\begin{array}{r}17018.15 \\
0 \mid\end{array}$ & $\frac{1481.85}{12200}$ & $\begin{array}{l}0.11111 \\
0.0203 \mid\end{array}$ & $\begin{array}{l}0.0055 \\
0.0008\end{array}$ & $\begin{array}{l}0.0015 \\
0.0022\end{array}$ & $\begin{array}{l}4888.89 \\
4163.71\end{array}$ & $\begin{array}{l}0.0437 \\
0.0363\end{array}$ & $\begin{array}{l}0.0131 \\
0.0338 \\
\end{array}$ & $\frac{0.0200}{0.0367}$ \\
\hline Formaldehyde & 0 & 19000 & 10228.9 & 8771.1 & 0.0989 & 0.0000 & 0.0061 & 0.00 & 0.0000 & 0.0000 & 0.0061 \\
\hline $\begin{array}{l}\text { Xylene } \\
\end{array}$ & 4400 & 18500 & 0 & 18500 & & & & & & & 0.0000 \\
\hline Toluene & 4400 & 18250 & 0 & 18250 & & & & & & & $\overline{0.0000}$ \\
\hline Hydrochloric acid & & & 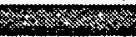 & & & & & & & & \\
\hline p-Xylene & 9600 & 18500 & 0 & 18500 & 0.4286 & 0.0233 & 0.0449 & 5485.71 & 0.0310 & 0.0255 & 0.0936 \\
\hline Terephthalic acid & 5500 & 18500 & 18500 & 0 & 0.1696 & 0.0053 & 0.0000 & 4567.25 & 0.0258 & 0.0026 & 0.0078 \\
\hline Ethylene oxide & 170 & 16000 & 0 & 16000 & 0.3158 & 0.0003 & 0.0281 & 116.32 & 0.0006 & 0.0005 & 0.0289 \\
\hline Ethylene glycol & 5600 & 9100 & 9100 & 0 & 0.0203 & 0.0006 & 0.0000 & 5486.30 & $0.028 \mathrm{I}$ & 0.0003 & 0.0009 \\
\hline Ammonium sulfate & 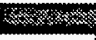 & & & & & & & & & & \\
\hline Cumene & 1025 & 20060 & 0 & 20060 & 0.0307 & 0.0001 & 0.0028 & 993.52 & 0.0045 & 0.0004 & \\
\hline Potash & & & & & & & & & & & \\
\hline Phenol & 6500 & 18700 & 18696.26 & 3.74 & 0.0309 & 0.0007 & 0.0000 & 6298.97 & 0.0234 & 0.0117 & 0.0124 \\
\hline Acetic acid & 4600 & 8300 & 8300 & 0 & 0.0101 & 0.0002 & 0.0000 & 4553.54 & 0.0164 & 0.0016 & 0.0018 \\
\hline Butadiene & 22000 & 24750 & 0 & 24750 & 0.4815 & 0.0337 & 0.0379 & 11407.41 & 0.0363 & 0.0091 & 0.08 \\
\hline Carbon black & & & & & & & & & & & \\
\hline Acrylonitrile & 2600 & 28000 & 14246.4 & 13753.6 & 0.5038 & 0.0037 & 0.0196 & 1290.23 & 0.0037 & 0.0002 & 0.0235 \\
\hline Propylene oxide & 7000 & 21000 & 19950 & 1050 & 0.1111 & 0.0021 & 0.0003 & 6222.22 & 0.0168 & 0.0131 & 0.0155 \\
\hline Vinyl acetate & 6650 & 12830 & 11675.3 & 1154.7 & 0.1111 & 0.0020 & 0.0003 & 5911.11 & 0.0157 & 0.0134 & 0.0157 \\
\hline \begin{tabular}{|l|} 
Titanium dioxide \\
Acetone \\
\end{tabular} & 5630 & 15800 & 14406.44 & 1393.56 & 0.1338 & 0.0018 & 0.0004 & $\begin{array}{r}8.8 \% \\
4876.78 \\
\end{array}$ & 0.0117 & 0.0058 & 0.0081 \\
\hline Cyclohexane & 340 & 17100 & 0 & 17100 & 0.0020 & 0.0000 & 0.0001 & 339.32 & 0.0007 & 0.0000 & 0.0001 \\
\hline \begin{tabular}{|l} 
Aluminum sulfate \\
Sodium silicate \\
\end{tabular} & & & & & & & & & 84 & 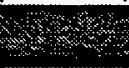 & \\
\hline Adipic acid & 12500 & 16000 & 13784 & 2216 & 0.1111 & 0.0024 & 0.0004 & 11111.11 & 0.0194 & 0.0175 & 0.0204 \\
\hline Calcium chloride & & & & & & & & & & & \\
\hline Caprolactam & 3400 & 16000 & $13392 \mid$ & 2608 & 0.1080 & 0.0005 & 0.0004 & 3032.69 & 0.0042 & 0.0002 & 0.0011 \\
\hline \begin{tabular}{|l|} 
Sodium sulfate \\
Isobutylene \\
\end{tabular} & & 12000 & $\begin{array}{r}0 \\
0 \mid\end{array}$ & $\begin{array}{r}12000 \mid \\
\quad 12\end{array}$ & $\begin{array}{r}0 \\
\quad 0.0203 \mid \\
\end{array}$ & $\begin{array}{r}0.0000 \\
\quad 0.048 \\
\end{array}$ & 0.0003 & & 0.0000 & 0.0000 & 0.0003 \\
\hline & & & & & & & & & & & \\
\hline Sum & & & & & & 0.1459 & 0.2380 & & & 0.4482 & 0.8320 \\
\hline & & & & & & & & & & & \\
\hline normalized fraction & & & & & & 0.1753531 & 0.28600424 & & & 0.538643 & \\
\hline$\%$ & & & & & & 17.54 & 28.60 & & . & $\mathbf{5 3 . 8 6}$ & \\
\hline & & & & & & & & & & & \\
\hline
\end{tabular}




\begin{tabular}{|c|c|c|c|c|}
\hline Chemical & $\begin{array}{l}\% \text { used to } \\
\text { produce top } \\
12 \text { polymers }\end{array}$ & \begin{tabular}{|} 
Total energy \\
savings for \\
polymer \\
precursors \\
(Q/yr)
\end{tabular} & \begin{tabular}{|c|} 
Wasted \\
feedstock (bil \\
\$) on \\
polymer \\
precursors
\end{tabular} & $\begin{array}{l}\text { Lbs of } \mathrm{CO} 2 \\
\text { produced on } \\
\text { polymer } \\
\text { precursors }\end{array}$ \\
\hline Sulfuric acid & & 0 & 0 & $\overline{0}$ \\
\hline Nitrogen & & 0 & 0 & 0 \\
\hline Oxygen & 1 & 01 & 임 & $\overline{0}$ \\
\hline Ethylene & $81:$ & 0 & 0 & 0 \\
\hline Ammonia & & 01 & 0 & 0 \\
\hline Lime & 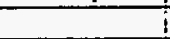 & 0 & 0 & $\overline{0}$ \\
\hline Phosphoric acid & & of & 0 & $\overline{0}$ \\
\hline Sodium hydroxide & & 0 & 0) & 0 \\
\hline Propylene & 46 & 0.045140526 & 0 & $\overline{0}$ \\
\hline Chlorine & $30 !$ & 0 & 0 & $\overline{0}$ \\
\hline Sodium carbonate & 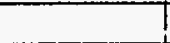 & 0 & 0 & 0 \\
\hline Urea & 6 & 0 & 0 & $\overline{0}$ \\
\hline Nitric acid & 10 & 0.000130807 & 0.003575 & 0 \\
\hline Ethylene dichloride & $88 !$ & 0.00954737 & 0.0643104 & 0.72248 \\
\hline Ammonium nitrate & & 0 & 0 & 0 \\
\hline Vinyl chloride & 84 & 0.037045989 & 0.2217684 & i. 16004 \\
\hline Benzene & 64 & 0 & 0 & 0 \\
\hline Ethylbenzene & & 0 & 0 & 0 \\
\hline MTBE & & 0 & 0 & 0 \\
\hline Carbon dioxide & & 0 & 0 & 0 \\
\hline Styrene & 77 & 0.015436424 & 0.1438668 & 1.76946 \\
\hline Methanol & 27 & 0.009914552 & 0 & 0.05751 \\
\hline Formaldehyde & 29 & 0.001755936 & 0.014577952 & 0.3132 \\
\hline Xylene & & 0 & 0 & 0 \\
\hline Toluene & 4 & of & 0 & 0 \\
\hline Hydrochloric acid & & 0 & 0 & 0 \\
\hline p-Xylene & 1001 & 0.093622869 & 0.133719 & 0 \\
\hline Terephthalic acid & 99 & 0.007758265 & 0.067716 & 0.62271 \\
\hline Ethylene oxide & 28 & 0.008103431 & 0.0875728 & 0.98336 \\
\hline Ethylene glycol & 291 & 0.000250286 & 0.0053505 & 0.02378 \\
\hline Ammonium sulfate & & 0 & 0 & 0 \\
\hline Cumene & 63 & 0.002122038 & 0 & 0 \\
\hline Potash & & 0 & 0 & 0 \\
\hline Phenol & 54 & 0.006712654 & 0.015768 & 0.26082 \\
\hline Acetic acid & & 0 & $\begin{array}{r}0 \mid \\
\end{array}$ & 0 \\
\hline Butadiene & 16 & 0.012903733 & 0.0660608 & 0.7984 \\
\hline Carbon black & & 0 & 0 & 0 \\
\hline Acrylonitrile & 18 & 0.004229442 & 0.0261927 & 0.29322 \\
\hline Propylene oxide & 17 & 0.00263823 & 0.008208025 & 0.27081 \\
\hline Vinyl acetate & & 0 & 0 & 0 \\
\hline Titanium dioxide & & 0 & 0 & $\mathbf{0}$ \\
\hline Acetone & & 0 & 01 & $\overline{0}$ \\
\hline Cyclohexane & 82 & $6.94853 \mathrm{E}-05$ & 0.000468384 & 0.01148 \\
\hline Aluminum sulfate & & 0 & 0 & 0 \\
\hline Sodium silicate & & 0 & 0 & 0 \\
\hline Adipic acid & 74 & 0.015067469 & 0.01495984 & 0.26048 \\
\hline Calcium chloride & & 0 & \begin{tabular}{r|}
0 \\
\end{tabular} & $\mathbf{0}$ \\
\hline Caprolactam & 87 & 0.000961318 & 0.0819279 & 0.30276 \\
\hline Sodium sulfate & & 0 & 0 & 0 \\
\hline Isobutylene & & 0 & 0 & $\overline{0}$ \\
\hline & & & & . \\
\hline Sum & & 0.273410824 & 0.956042501 & 7.85051 \\
\hline \multicolumn{5}{|l|}{ normalized fraction } \\
\hline$\%$ & & 32.86 & 47.29 & 37.56 \\
\hline
\end{tabular}




\section{APPENDIX II \\ Calculation of Excess Feedstock Required and Carbon Dioxide Generated}

(attached file: waste1.xls) 


\begin{tabular}{|c|c|c|c|c|c|c|c|c|}
\hline Chemical & $\begin{array}{l}\text { Production Ib } \\
\text { (bil) } 92\end{array}$ & Process & Feedstock & $\begin{array}{c}\text { Total } \\
\text { Feedstock } \\
\text { Conversion } \\
\% \\
\end{array}$ & $\begin{array}{l}\text { Product } \\
\text { yield } \\
\text { Mol\% }\end{array}$ & $\begin{array}{c}\text { Biproduct } \\
\text { Yield } \\
\text { Mol\% }\end{array}$ & $\begin{array}{c}\text { Feedstock } \\
\text { Waste .. lb } \\
\text { (bil) }\end{array}$ & $\begin{array}{c}\text { Feedstock } \\
\text { unit cost } \\
\$ / \mathrm{b}\end{array}$ \\
\hline Sulfuric acid & 88.8 & i catalytic conversion & $\mathrm{SO} 2$ & $99.70 \%$ & $99.20 \%$ & $0.00 \%$ & .467 & .115 \\
\hline & & & air & Not Specified & N/A & $0.00 \%$ & NA & NA \\
\hline \begin{tabular}{|l} 
Nitrogen \\
Oxygen
\end{tabular} & $\begin{array}{c}58.7 \\
42.38\end{array}$ & & & 4 & 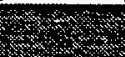 & $28 \%$ & & \\
\hline Ethylene & 40.41 & & & & & & & \\
\hline \multirow[t]{2}{*}{ Ammonia } & 35.95 & I ammonia synthesis & hydrogen & $88.00 \%$ & $87.12 \%$ & $0.00 \%$ & .625 & \\
\hline & & & air (N2) & $\mathrm{NA}$ & $\mathrm{NA}$ & $\mathrm{NA}$ & NA & NA \\
\hline Lime & 34.72 & & & & & & & \\
\hline Phosphoric acid & 25.36 & & & & & & & \\
\hline Sodium hydroxide & $\begin{array}{l}\cdot 24.02 \\
\end{array}$ & 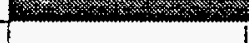 & 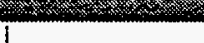 & & 3 & & & \\
\hline Propylene & 22.6 & Catalytic reforming & ethane & $95.00 \%$ & $1.71 \%$ & $93.29 \%$ & .000 & \\
\hline Chlorine & 22.28 & & & & & & .000 & \\
\hline Sodium carbonate & 20.89 & & & & & & & \\
\hline Urea & 16.84 & & & & & & & 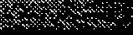 \\
\hline \multirow[t]{2}{*}{ Nitric acid } & 16.08 & Oxidation & ammonia & $99.00 \%$ & $94.05 \%$ & $0.00 \%$ & .275 & .130 \\
\hline & & & air (oxygen) & $90.00 \%$ & NA & NA & NA & NA \\
\hline \multirow[t]{2}{*}{ Ethylene dichloride } & 15.94 & Oxychlorination & ethylene & $95.00 \%$ & $94.05 \%$ & $0.50 \%$ & .261 & .280 \\
\hline & & & chlorine & $100.00 \%$ & & & & .108 \\
\hline Ammonium nitrate & 15.33 & & 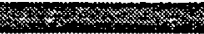 & 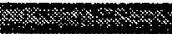 & $\operatorname{sen} x$ & & & 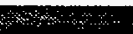 \\
\hline Vinyl chloride & 13.23 & $\begin{array}{c}\text { thermal } \\
\text { decomposition }\end{array}$ & $\begin{array}{c}\text { ethylene } \\
\text { dichloride }\end{array}$ & $95.00 \%$ & $93.10 \%$ & $0.00 \%$ & 1.553 & .170 \\
\hline Benzene & 12.01 & Catalytic reforming & naptha & NA & NA & NA & NA & .148 \\
\hline \multirow[t]{2}{*}{ Ethylbenzene } & 10.99 & Alkylation & ethylene & $99.00 \%$ & $98.01 \%$ & $1.00 \%$ & .029 & .280 \\
\hline & & & benzene & $100.00 \%$ & $98.01 \%$ & & .164 & .143 \\
\hline \multirow[t]{2}{*}{ MTBE } & 10.86 & Reactive distillation & methanol & $99.00 \%$ & $99.00 \%$ & $0.00 \%$ & .096 & .068 \\
\hline & & & isobutylene & $100.00 \%$ & $99.00 \%$ & $1.00 \%$ & .000 & .310 \\
\hline Carbon dioxide & 10.79 & 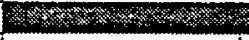 & 20 & $28-28$ & 28 & 5 mo & 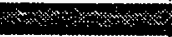 & 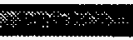 \\
\hline Styrene & 8.94 & Dehydrogenation & ethylbenzene & $100.00 \%$ & $90.00 \%$ & $3.15 \%$ & .693 & .270 \\
\hline \multirow[t]{2}{*}{ Methanol } & 8.73 & Methanol synthèsis & carbon monoxide & $99.00 \%$ & $98.01 \%$ & $0.00 \%$ & .155 & \\
\hline & & & hydrogen & not specified & $\begin{array}{c}\text { not } \\
\text { specified }\end{array}$ & not specified & not specified & \\
\hline \multirow[t]{2}{*}{ Formaldehyde } & 6.98 & Dehydrogenation & methanol & $100.00 \%$ & $91.00 \%$ & $0.00 \%$ & .736 & .068 \\
\hline & & & air (oxygen) & $100.00 \%$ & $\mathrm{NA}$ & $0.00 \%$ & NA & NA \\
\hline Xylene & 6.38 & Catalytic reforming & naptha & NA & NA & NA & NA & .148 \\
\hline Toluene & 6.03 & Catalytic reforming & naptha & $N A$ & $\mathrm{NA}$ & NA & NA & .148 \\
\hline Hydrochloric acid & 5.75 & 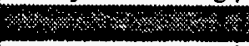 & $2 \times+4 \%$ & क०ष & 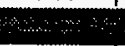 & $6 n$ & & \\
\hline p-Xylene & 5.66 & isomerization & $\begin{array}{c}\text { mixed xylenes } \\
\text { and ethylbenzene }\end{array}$ & $100.00 \%$ & $70.00 \%$ & $19.60 \%$ & .841 & .159 \\
\hline \multirow[t]{2}{*}{ Terephthalic acid } & 5.64 & Air oxidation & p-xylene & $95.00 \%$ & & $0.00 \%$ & .190 & .360 \\
\hline & & & air & $100.00 \%$ & NA & NA & NA & NA \\
\hline \multirow[t]{2}{*}{ Ethylene oxide } & 5.56 & $\begin{array}{c}\text { Oxidation } \\
\text { (epoxidation) }\end{array}$ & ethylene & $95.00 \%$ & $76.00 \%$ & $0.00 \%$ & 1.117 & .280 \\
\hline & & & oxygen & $100.00 \%$ & NA & NA & NA & \\
\hline \multirow[t]{2}{*}{ Ethylene glycol } & 5.12 & Hydration & ethylene oxide & $99.00 \%$ & $89.10 \%$ & $9.90 \%$ & .041 & .450 \\
\hline & & & water & NA & $\mathrm{NA}$ & $\mathrm{NA}$ & NA & NA \\
\hline Ammonium sulfate & 4.72 & & & & & & & \\
\hline Cumene & 4.57 & alkylation & benzene & $98.00 \%$ & $97.02 \%$ & $2.98 \%$ & .000 & .143 \\
\hline
\end{tabular}




\begin{tabular}{|c|c|c|c|c|c|c|c|c|}
\hline Chemical & Production lb & Process & Feedstock & $\begin{array}{c}\text { Total } \\
\text { Feedstock } \\
\text { Conversion } \\
\% \\
\end{array}$ & $\begin{array}{c}\text { Product } \\
\text { yield } \\
\text { Mol\% } \\
\end{array}$ & $\begin{array}{c}\text { Biproduct } \\
\text { Yield } \\
\text { Mol\% } \\
\end{array}$ & $\begin{array}{c}\text { Feedstock } \\
\text { Waste -- lb } \\
\text { (bii) } \\
\end{array}$ & $\begin{array}{c}\text { Feedstock } \\
\text { unit cost } \\
\$ / \mathrm{b}\end{array}$ \\
\hline & $i$ & & propylene & $100.00 \%$ & $92.00 \%$ & $8.00 \%$ & .000 & .223 \\
\hline Potash & 3.76 & & 2 & 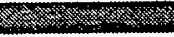 & 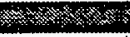 & $8 \times$ & os: & sos. \\
\hline Phenol & 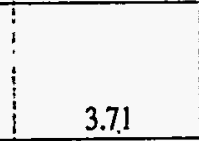 & Icumene peroxidation & cumene & $100.00 \%$ & $97.00 \%$ & $0.00 \%$ & .146 & .200 \\
\hline & $T$ & $5+2$ & air & $100.00 \%$ & NA & NA & $\mathrm{NA}$ & $\mathrm{NA}$ \\
\hline Acetic acid & 3.6 & $\begin{array}{c}\text { methanol } \\
\text { carbonylation }\end{array}$ & $\frac{\text { methanol }}{\text { |carbon monoxide }}$ & $\frac{100.00 \%}{90.00 \%}$ & $\frac{99.00 \%}{89.10 \%}$ & $\frac{0.00 \%}{0.00 \%}$ & .027 & .068 \\
\hline Butadiene & 3.18 & $\begin{array}{c}\text { oxidative } \\
\text { dehydrogenation } \\
\end{array}$ & $\begin{array}{l}\text { mixed linear } \\
\text { butenes }\end{array}$ & $75.00 \%$ & $67.50 \%$ & $0.00 \%$ & 1.588 & .260 \\
\hline & & & Steam & Not Specified & $\begin{array}{c}\text { Not } \\
\text { Specified }\end{array}$ & none & Not Specified & NA \\
\hline Carbon black & 3.02 & & m & 28 & 2 & 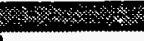 & & \\
\hline Acrylonitrile & 2.83 & $\begin{array}{l}\text { ammoxidation } \\
\text { (oxidative } \\
\text { amination) } \\
\end{array}$ & propylene & $100.00 \%$ & $66.50 \%$ & $14.10 \%$ & .654 & .223 \\
\hline & & - & ammonia & Not specified & $\begin{array}{c}\text { Not } \\
\text { specified }\end{array}$ & $\begin{array}{c}\text { Not } \\
\text { specified }\end{array}$ & Not specified & .130 \\
\hline & & & air & Not specified & $\begin{array}{c}\text { Not } \\
\text { specified }\end{array}$ & $\begin{array}{c}\text { Not } \\
\text { specified }\end{array}$ & Not specified & NA \\
\hline Propylene oxide & 2.7 & peroxidation & propylene & $100.00 \%$ & $90.00 \%$ & $0.00 \%$ & .217 & .223 \\
\hline & & & $\begin{array}{c}\text { isobutane } \\
\text { (ethylbenzene) }\end{array}$ & $100.00 \%$ & $90.00 \%$ & $0.00 \%$ & .300 & \\
\hline & & & oxygen & $100.00 \%$ & $90.00 \%$ & $0.00 \%$ & .166 & \\
\hline Vinyl acetate & 2.66 & catalytic oxidation & ethylene & $100.00 \%$ & $90.00 \%$ & $0.00 \%$ & .096 & .280 \\
\hline & & & acetic acid & $100.00 \%$ & $100.00 \%$ & $0.00 \%$ & .000 & .330 \\
\hline & & & oxygen & $100.00 \%$ & $90.00 \%$ & $0.00 \%$ & .110 & \\
\hline Titanium dioxide & 2.53 & 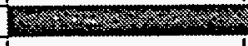 & 1 & $=$ & $8+48$ & 40 & 40 & 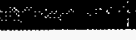 \\
\hline Acetone & 2.39 & cumene peroxidation & cumene & NA & NA & NA & NA & .200 \\
\hline Cyclohexane & 2.21 & hydrogenation & $\begin{array}{c}\text { air } \\
\text { benzene }\end{array}$ & $\begin{array}{c}\text { NA } \\
99.80 \%\end{array}$ & $\begin{array}{c}\text { NA } \\
99.80 \%\end{array}$ & $\begin{array}{c}\text { NA } \\
0.00 \%\end{array}$ & $\begin{array}{l}\text { NA } \\
.004\end{array}$ & $\begin{array}{c}\text { NA } \\
.143\end{array}$ \\
\hline & & & hydrogen & $92.40 \%$ & $92.40 \%$ & $0.00 \%$ & .004 & \\
\hline \begin{tabular}{|l|} 
Aluminum sulfate \\
Sodium silicate \\
\end{tabular} & $\begin{array}{l}2.18 \\
1.8 \\
\end{array}$ & & & & 6 & & & \\
\hline Adipic acid & 1.75 & catalytic oxidation & cyclohexane & $100.00 \%$ & $90.00 \%$ & $0.00 \%$ & .112 . & .181 \\
\hline - & & & nitric acid & Not specified & $\begin{array}{c}\text { Not } \\
\text { specified }\end{array}$ & $0.00 \%$ & Not specified & .183 \\
\hline & & & air & $100.00 \%$ & $\begin{array}{c}\text { Not } \\
\text { specified }\end{array}$ & $0.00 \%$ & Not specified & NA \\
\hline Calcium chloride & 1.39 & & $=0$ & 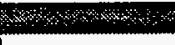 & 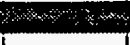 & $m \times$ & 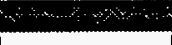 & \\
\hline Caprolactam & 1.38 & $\begin{array}{c}\text { Beckman } \\
\text { rearrangement }\end{array}$ & cyclohexanone & $95.00 \%$ & $90.25 \%$ & $0.00 \%$ & .129 & .730 \\
\hline & & & hydroxylamine & Not specified & $\begin{array}{c}\text { Not } \\
\text { specified }\end{array}$ & $\begin{array}{c}\text { Not } \\
\text { specified }\end{array}$ & Not specified & NA \\
\hline Sodium sulfate & 1.34 & & 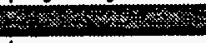 & - & $4 \times 4 \times$ & & & \\
\hline Isobutylene & 1.29 & $\begin{array}{c}\text { dehydrogenation, } \\
\text { isomerization }\end{array}$ & n-butanes & $99.00 \%$ & $98.01 \%$ & $0.00 \%$ & .027 & .260 \\
\hline Sum & 655.98 & & & & & & 11.030 & \\
\hline
\end{tabular}




\begin{tabular}{|c|c|c|c|c|c|c|}
\hline Chemical & $\begin{array}{l}\text { Feedstock } \\
\text { Waste } \\
\text { \$1billion }\end{array}$ & $\begin{array}{c}\text { No-value } \\
\text { Hydrocarbon Co- } \\
\text { and byproducts }\end{array}$ & $\begin{array}{l}\text { Feedstock Waste } \\
\text { CO2 Equivalent }\end{array}$ & $\begin{array}{l}\text { Valuable Co- and } \\
\text { Byproducts }\end{array}$ & Other Notes & References \\
\hline \multirow[t]{2}{*}{ Sulfuric acid } & .054 & none & .000 & none & 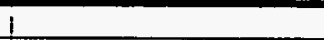 & \\
\hline & NA & NA & .000 & none & & \\
\hline \multicolumn{7}{|l|}{ Oxygen } \\
\hline \multirow[t]{2}{*}{ Ammonia } & .000 & none & .000 & none & & \\
\hline & NA & none & NA & NA & & \\
\hline \multicolumn{7}{|l|}{\begin{tabular}{|l|} 
Lime \\
Phosphoric acid \\
Sodium hydroxide \\
\end{tabular}} \\
\hline Propylene & .000 & 0 & .000 & $\begin{array}{l}\text { Other hydrocarbon } \\
\text { fractions }\end{array}$ & & $\begin{array}{l}\text { Hatch and Matar 1981, p. } \\
74\end{array}$ \\
\hline \multicolumn{7}{|l|}{ Chlorine } \\
\hline \multirow[t]{2}{*}{ Nitric acid } & .036 & none & .000 & none & & \\
\hline & NA & none & NA & NA & & \\
\hline \multirow[t]{2}{*}{ Ethylene dichloride } & .073 & $\begin{array}{c}\mathrm{C} 1 \text { and } \mathrm{C} 2 \text { carbon } \\
\text { oxides and chlorides }\end{array}$ & .821 & none & ? & $\begin{array}{l}\text { McKetta, 1984, V.20, p. } \\
213\end{array}$ \\
\hline & .000 & & & & & \\
\hline \multicolumn{7}{|l|}{ Ammonium nitrate } \\
\hline Vinyl chloride & .264 & chlorinated carbons & $1.381^{\circ}$ & & & - \\
\hline Benzene & NA & NA & NA & $\begin{array}{l}\text { Other hydrocarbon } \\
\text { fractions }\end{array}$ & & \\
\hline Ethylbenzene & .008 & none & .092 & polyethylbenzenes & & Hatch and Matar, p. 138 \\
\hline & .023 & & .556 & & & \\
\hline \multirow[t]{2}{*}{ MTBE } & .007 & methanol purge & .096 & $\begin{array}{c}\text { (unreactive C4 } \\
\text { hydrocarbons added } \\
\text { with feed) }\end{array}$ & $\begin{array}{l}\text { unreacted } \mathrm{MeOH} \text {, and } \mathrm{C4} \\
\text { hydrocarbons allowed in } \\
\text { gasoline product }\end{array}$ & $\begin{array}{l}\text { Hatch and Matar 1981,p } \\
128\end{array}$ \\
\hline & .000 & none & .000 & $\begin{array}{c}\text { t-butyl alcohol; } \\
\text { diisobutylene }\end{array}$ & $\begin{array}{l}\text { biproducts can be used in } \\
\text { gasoline }\end{array}$ & $\begin{array}{l}\text { HP 1995, p. 112; } \\
\text { Chemical Engineering } \\
\text { 1979, p. 209 }\end{array}$ \\
\hline \multicolumn{7}{|c|}{ W } \\
\hline Styrene & .187 & tar, $\mathrm{CO}, \mathrm{CO} 2$ & 2.302 & $\begin{array}{c}\text { Toluene }(.031 \mathrm{~kg} / \mathrm{kg} \\
\text { styrene) }\end{array}$ & $\cdot$ & $\begin{array}{l}\text { Hatch and Matar 1981, p. } \\
\text { 138, Chemical } \\
\text { Engineering, 1079, p. } \\
\text { 269, Lowenheim and } \\
\text { Moran, 1975, p. 782 }\end{array}$ \\
\hline \multirow[t]{2}{*}{ Methanol } & .000 & \begin{tabular}{|c|} 
ethers, esters, \\
acetone, \\
hydrocarbons, higher \\
alcohols \\
\end{tabular} & .213 & none & & . \\
\hline & NA & NA & .000 & none & & \\
\hline \multirow[t]{2}{*}{ Formaldehyde } & .050 & carbon dioxide & 1.080 & none & & \\
\hline & NA & NA & $\mathrm{NA}$ & none & & \\
\hline Xylene & NA & NA & NA & Other Hydrocarbons & & \\
\hline Toluene & NA & NA & NA & Other Hydrocarbons & & \\
\hline \multicolumn{7}{|l|}{ Hydrochloric acid } \\
\hline $\mathrm{p}$-Xylene & 134 & m-xylene & .000 & $\begin{array}{c}\text { C7- hydrocarbons and } \\
\text { C9+ aromatics }\end{array}$ & $\begin{array}{l}\text { HP } 1995 \text { inidcates } 87-95 \% \\
\text { selectivity at } 30 \% \\
\text { conv./pass; } 70 \% \text { overall } \\
\text { yield of p-xylene with } \\
19.6 \% \text { o-xylene } \\
\text { coproduced. }\end{array}$ & $\begin{array}{l} \\
\text { HP1995, p. } 149 \\
\text { Pearce and Patterson } \\
1981, \text { p. } 210-12\end{array}$ \\
\hline Terephthalic acid & .068 & $\begin{array}{c}\text { 4-carboxy } \\
\text { benzaldehyde }\end{array}$ & .629 & none & $\begin{array}{l}90 \% \text { selectivity at } 95 \% \\
\text { conversion }\end{array}$ & $\begin{array}{l}\text { Pearch and Patterson } \\
1981, \text { p. 284 }\end{array}$ \\
\hline & NA & none & NA & none & & \\
\hline \multirow[t]{2}{*}{ Ethylene oxide } & .313 & $\mathrm{CO} 2$ & 3.512 & & & \\
\hline & NA & none & NA & none & & \\
\hline \multirow[t]{2}{*}{ Ethylene glycol } & .018 & not specified & .082 & $\begin{array}{l}\text { diethylene glycol, } \\
\text { triethylene glycol }\end{array}$ & $\begin{array}{l}\text { Yield >99.5; } 102 \mathrm{lb} \\
\text { diethylene- and } 5 \mathrm{lb} \\
\text { triethylene-glycols/1000 lb } \\
\text { ethylene glycol }\end{array}$ & Chemical engineering \\
\hline & NA & NA & NA & NA & & \\
\hline \multicolumn{7}{|l|}{ Ammonium sulfate } \\
\hline Cumene & .000 & none & .000 & $\begin{array}{c}\text { polyalkylated } \\
\text { benzenes }\end{array}$ & & $\begin{array}{l}\text { Lowenheim and Moran } \\
1975, \text { p. } 295\end{array}$ \\
\hline
\end{tabular}




\begin{tabular}{|c|c|c|c|c|c|c|}
\hline Chemical & $\begin{array}{l}\text { Feedstock } \\
\text { Waste } \\
\text { \$1billion }\end{array}$ & $\begin{array}{c}\text { No-value } \\
\text { Hydrocarbon Co- } \\
\text { and byproducts }\end{array}$ & \begin{tabular}{|l} 
Feedstock Waste \\
CO2 Equivalent
\end{tabular} & $\begin{array}{c}\text { Valuable Co- and } \\
\text { Byproducts }\end{array}$ & Other Notes & References \\
\hline & .000 & none & .000 & $\begin{array}{l}\text { polyalkylated } \\
\text { benzenes }\end{array}$ & $\begin{array}{l}\text { reacted with balance used } \\
\text { in making heavier } \\
\text { aromatics }\end{array}$ & $\begin{array}{l}\text { Chenier 1986, p. } 178 \\
\text { Chemical Engineering } \\
1979, \text { p. 152-4 }\end{array}$ \\
\hline \multicolumn{7}{|c|}{ 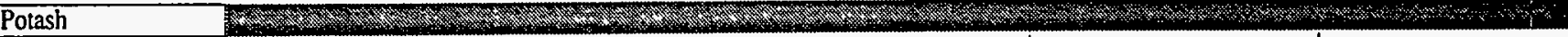 } \\
\hline Phenol & .029 & $\operatorname{tars}$ & .483 & & $\begin{array}{l}97 \% \text { achievable by } \\
\text { hydrogentating a- } \\
\text { methylstyrene to cumene } \\
\text { and recycling. }\end{array}$ & HP 1995, p. 133 \\
\hline & NA & none & $0.00 \%$ & NA & & \\
\hline Acetic acid & .002 & $\begin{array}{c}\text { propionic acid, flare } \\
\text { gas } \\
\end{array}$ & .027 & none & & $\begin{array}{l}\text { Moran and Lowenheim } \\
1975, \text { p. } 10\end{array}$ \\
\hline & .000 & NA & .323 & none & & Leach 1983, p. 278 \\
\hline \multirow[t]{2}{*}{ Butadiene } & .413 & $\begin{array}{c}\text { vinylacetylene, } \\
\text { formaldehyde, } \\
\text { acetaldehyde, } \\
\text { acrolein } \\
\end{array}$ & 4.990 & none & - & - \\
\hline & NA & NA & 0 & none & - & \\
\hline \multicolumn{7}{|l|}{ Carbon black } \\
\hline \multirow[t]{3}{*}{ Acrylonitrile } & .146 & $\mathrm{CO}, \mathrm{CO} 2$, acrolein & 1.629 & $\begin{array}{c}\text { acetonitrile, hydrogen } \\
\text { cyanide }\end{array}$ & $\begin{array}{l}\text { One } \mathrm{kg} \text { propylene yields } \\
0.84 \mathrm{~kg} \text { acrylonitrile, } 0.03 \\
\mathrm{~kg} \text { acetonitrile and } 0.13 \mathrm{~kg} \\
\text { hydrogen cyanide }\end{array}$ & $\begin{array}{l}\text { Lowenheim and } \\
\text { Moran,1975, p. 46-7 }\end{array}$ \\
\hline & NA & NA & .000 & $\begin{array}{c}\text { acetonitrile, hydrogen } \\
\text { cyanide }\end{array}$ & & \\
\hline & NA & NA & .000 & NA & & \\
\hline \multirow[t]{3}{*}{ Propylene oxide } & .048 & Not specified & .683 & $\begin{array}{c}\text { Tert-butyl alcohol (to } \\
\text { make isobutylene or } \\
\text { MTBE) [a- } \\
\text { phenylethyl alcohol ( } \\
\text { to make styrene)] } \\
\end{array}$ & $\begin{array}{l}93 \% \text { yield; } 2.2 \mathrm{~kg} \text { t-butyl } \\
\text { alcohol } / \mathrm{kg} \text { propylene.oxide }\end{array}$ & $\begin{array}{l}\text { Lowenheim and Moran } \\
\text { 1975, p. } 695\end{array}$ \\
\hline & .000 & Not specified & $.910^{\circ}$ & NA & & \\
\hline & .000 & Not specified & .000 & NA & & \\
\hline \multirow[t]{3}{*}{ Vinyl acetate } & .027 & $\mathrm{CO} 2$, acetaldehyde & .302 & none & & $\begin{array}{l}\text { Pearce and Patterson } \\
1981, \text { p. } 270\end{array}$ \\
\hline & .000 & \begin{tabular}{|c|} 
none \\
\end{tabular} & .000 & none & & \\
\hline & .000 & none & .000 & none & & \\
\hline \multicolumn{7}{|l|}{ Titanium dioxide } \\
\hline \multirow[t]{2}{*}{ Acetone } & NA & $\mathrm{NA}$ & NA & NA & $\begin{array}{l}\text { coproduct of phenol } \\
\text { production form cumene }\end{array}$ & \\
\hline & NA & NA & NA & NA & & \\
\hline \multirow[t]{2}{*}{ Cyclohexane } & .001 & unreacted benzene & .014 & none & & \\
\hline & & NA & .000 & none & & $\begin{array}{l}\text { McKetta 1982, vol 14, p } \\
70-1,76-7\end{array}$ \\
\hline \multicolumn{7}{|l|}{\begin{tabular}{|l} 
Aluminum sulfate \\
Sodium silicate \\
\end{tabular}} \\
\hline \multirow[t]{3}{*}{ Adipic acid } & .020 & $\begin{array}{c}\text { esters and ethers, } \\
\text { dicarboxylic acids, } \\
\text { glutaric and succinic } \\
\text { acids } \\
\end{array}$ & .352 & none & $90-96 \%$ yield & $\begin{array}{l}\text { Lowenheim and Moran } \\
\text { 1975, p. 52; Kirk Othme } \\
\text { 1991, vol. 1, P. } 476-80 \\
\end{array}$ \\
\hline & NA & NA & .000 & none & & \\
\hline & NA & NA & .000 & none & & \\
\hline \multicolumn{7}{|l|}{ Calcium chloride } \\
\hline \multirow[t]{2}{*}{ Caprolactam } & .094 & not specified & .348 & $\begin{array}{c}\text { Ammonium sulfate, } \\
\text { Hydrogen }\end{array}$ & $\begin{array}{l}1.750 \mathrm{lb} \mathrm{NH} 3 \mathrm{SO} 4 / \mathrm{lb} \\
\text { caprolactam, } 021 \mathrm{lb} \mathrm{H2/lb} \\
\text { caprolactam }\end{array}$ & $\begin{array}{l}\text { Chemical Engineering } \\
1979, \text { p. } 138\end{array}$ \\
\hline & NA & NA & .000 & NA & & \\
\hline \multicolumn{7}{|l|}{ Sodium sulfate } \\
\hline Isobutylene & .007 & none & .082 & Hydrogen & \begin{tabular}{|l|}
$89 \%$ isobutylene yield, $2.5-$ \\
$3 \%$ hydrogen yield
\end{tabular} & HP 1995, p. 104 \\
\hline Sum & 2.022 & & 20.907 & & & \\
\hline
\end{tabular}




\section{APPENDIX III}

Process Information and Limitations

(attached file: top50proc_ref.xls) 
top50proc_ref.xls

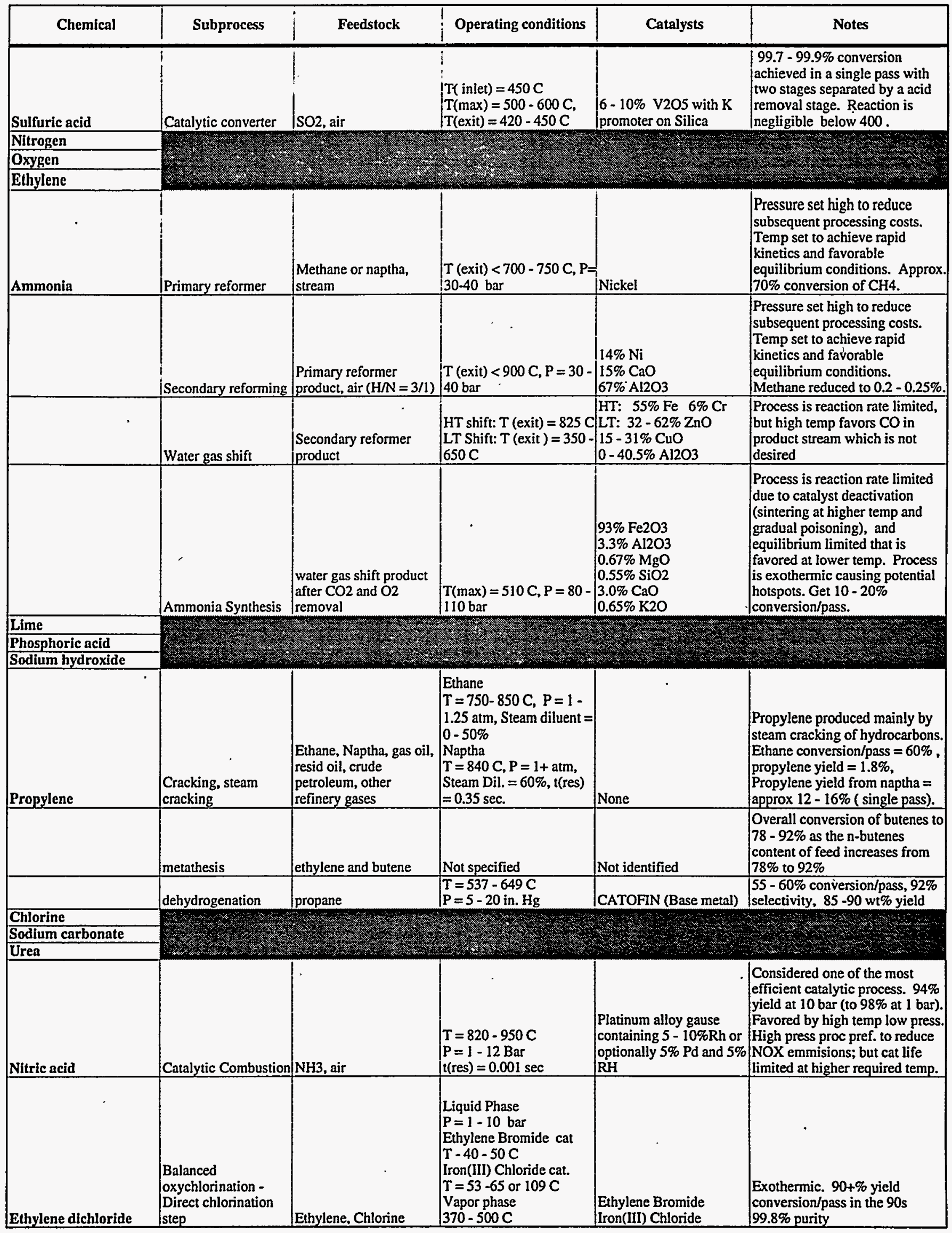




\begin{tabular}{|c|c|c|c|c|c|}
\hline Chemical & Subprocess & Feedstock & Operating conditions & Catalysts & Notes \\
\hline & $\begin{array}{l}\text { Balanced } \\
\text { oxychlorination - } \\
\text { loxychlorination step }\end{array}$ & $\begin{array}{l}\mid \\
\vdots \\
\vdots \\
\text { Ethylene, } \mathrm{HCl}, \text { air/O2 }\end{array}$ & $\mathrm{T}=225-315 \mathrm{C}$ & $\begin{array}{l}\text { Modified decontype } \\
\text { (Copper Chloride on } \\
\text { alumina; KCL, rare earth } \\
\text { chloride?) }\end{array}$ & Exothermic \\
\hline \multicolumn{6}{|c|}{ 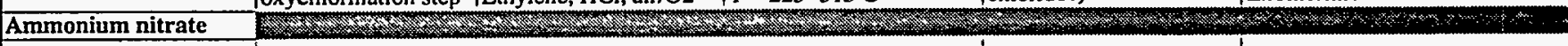 } \\
\hline Vinyl chloride & Pyrolysis & $\begin{array}{l}\text { Ethylene dichloride } \\
\text { E. }\end{array}$ & $\begin{array}{l}\mathrm{T}=430-530 \mathrm{C} \\
\mathrm{P}=10-35 \mathrm{Bar}\end{array}$ & Pumice or Charcoal & $\begin{array}{l}50-60 \% \text { conversion. } 95 \% \\
\text { selectivity }\end{array}$ \\
\hline \multirow[t]{4}{*}{ Benzene } & $\begin{array}{l}\mid \\
\text { lCatalytic Reforming } \\
\text { (hydroforming. } \\
\text { |platforming, } \\
\text { Iheniforming) }\end{array}$ & \begin{tabular}{|l|} 
\\
Naptha \\
(cyclohexane,methyl \\
cyclopentane)
\end{tabular} & $\begin{array}{l}\text { Pt Catalyst } \\
T=450-510 \mathrm{C} \\
\mathrm{P}=250-800 \mathrm{psi} \\
\mathrm{Pt} / \mathrm{RH} \text { Catalyst } \\
\mathrm{t}=480-540 \mathrm{C} \\
\mathrm{P}=100-200 \mathrm{psig}\end{array}$ & $\begin{array}{l}\text { Platinum metal on } \\
\text { alumina support, } \mathrm{Pt},-\mathrm{Rh}\end{array}$ & $\begin{array}{l}\text { Endothermic reaction reg. } \\
\text { interstage heating } 80 \% \\
\text { yield/pass from C6 napthenes+ } 1 \\
-9 \% \text { in feed, Gross yld of } \\
\text { aromatics }=90-95 \% \text { of } \\
\text { theoretical. Higher ylds from } \\
\text { Pt/Rh cat. (High temp/ Lower } \\
\text { press) Cats. sulfur sensitive, } \\
\text { deactivate faster at low P. }\end{array}$ \\
\hline & Hydrodealkylation & $\begin{array}{l}\text { Toluene or toulene rich } \\
\text { feedstocks, hydrogen }\end{array}$ & $\begin{array}{l}T=550-650 \mathrm{C} \\
\mathrm{p}=375-750 \mathrm{psi}\end{array}$ & $\begin{array}{l}\mathrm{Ni}, \mathrm{Cr}, \mathrm{Mo} \text { or } \mathrm{Co} \\
\text { supported on alumina or } \\
\text { Silica-alumina }\end{array}$ & $\begin{array}{l}\text { Exothermic Rx. } 96+\% \text { yield. } \\
\text { Some hydrocracking occurs } \\
\text { producing } \mathrm{Cl} \text { to C6 Paraffins. } \\
\text { some biphenyl and polycyclics } \\
\text { produced. }\end{array}$ \\
\hline & Hydrodealkylation & Toluene, steam & $\begin{array}{l}\mathrm{T}=600-800 \text { (most cat.) } \\
\mathrm{T}=320-630 \text { (Ni on } \\
\text { Ai2O3) }\end{array}$ & $\begin{array}{l}\text { Y, } \mathrm{La}, \mathrm{Ce}, \mathrm{Pr}, \mathrm{Nd}, \mathrm{Sm}, \\
\text { Th compounds: Nickel } \\
\text { on alumina }\end{array}$ & $90 \%$ yields \\
\hline & disproportionation & Toluene & $\begin{array}{l}\text { Co-Mo cat. } \\
\mathrm{T}=450-530 \mathrm{C} \\
\mathrm{P}=300 \text { Psig } \\
\mathrm{ZMS}-5 \text { Zeolite } \\
\mathrm{T}=480\end{array}$ & $\begin{array}{l}\text { ZMS-5 Zeolite } \\
\text { CoO-MoO3 on } \\
\text { aluminosilicat/alumina }\end{array}$ & $\begin{array}{l}40 \% \text { conversion/pass, } 97 \% \\
\text { yield. Equilibrium limited to } \\
58 \% \text { conversion, Conversion > } \\
40 \% \text { produces more side Rx. and } \\
\text { catalyst deact. } \\
\end{array}$ \\
\hline \multirow[t]{2}{*}{ Ethylbenzene } & $\begin{array}{l}\text { Liquid phase } \\
\text { alkylation }\end{array}$ & $\begin{array}{l}\text { Benzene (styrene grade), } \\
\text { ethylene }\end{array}$ & $\begin{array}{l}\mathrm{T}=40-100 \mathrm{CC} \\
\mathrm{P}=30-100 \mathrm{psi}\end{array}$ & $\begin{array}{l}\text { Aluminum chloride- } \\
\text { hyrdrogen chloride- } \\
\text { hydrocarbon complex }\end{array}$ & $\begin{array}{l}\text { 90-99+ overall yld. Approx. } \\
70 \% \text { sel. over polyethylbenzene } \\
\text { (PEB) in .proc. Used in styrerie } \\
\text { syn. proc. Friedle-Crafts } \\
\text { Alkylation. Excess Benzene to } \\
\text { min. PEB biprod. that is } \\
\text { recycled and conv. to ethylbenze } \\
\text { in reactor. } 100 \% \text { conv. } \\
\text { ethylene/pass }\end{array}$ \\
\hline & $\begin{array}{l}\text { Vapor phase } \\
\text { alkylátion }\end{array}$ & Benzene, ethylene & $\begin{array}{l}T=150-250 \cdot C \\
P=400-700 p s i\end{array}$ & Boron trifluoride & $\begin{array}{l}99+\% \text { yield. Multiple pass. } \\
\text { Designed to used high ethylene } \\
(8-10 \%) \text { refinery gas as } \\
\text { feedstock. Up to } 5-100 \% \\
\text { ethylene can be used. }\end{array}$ \\
\hline \multirow[t]{2}{*}{ - } & \begin{tabular}{|l} 
Mobil Badger \\
Process
\end{tabular} & $\begin{array}{l}\text { Ethylene, Benzene } \\
\text { (makeup) most benzene } \\
\text { may be a recycled } \\
\text { intermediate in the } \\
\text { process }\end{array}$ & $\begin{array}{l}T \\
T=370-420 \mathrm{C} \\
\mathrm{P}=200-400 \mathrm{psig}\end{array}$ & $\begin{array}{l}\text { Crystalline } \\
\text { aluminosilicate zeolite } \\
\text { (ZSM-5) }\end{array}$ & $\begin{array}{l}\text { Benzene/Ethylene }=7.5 / 1(5 / 1 \text { - } \\
20 / 1)\end{array}$ \\
\hline & $\begin{array}{l}\text { High Temperature } \\
\text { Process }\end{array}$ & $98 \%$ Ethylene? & $\begin{array}{l}T=260 C \\
P=900-950 p s i g\end{array}$ & solid phosphoric acid & None \\
\hline MTBE & & Methanol, Isobutylene & $\begin{array}{l} \\
\text { T(inlet) }=25 \mathrm{C} \\
\text { T(outlet) }=90 \mathrm{C} \\
\mathrm{P}>\text { latm to maintare } \\
\text { liquid phase }\end{array}$ & $\begin{array}{l}\text { acidic ion-exchage resin } \\
\text { such as ssulfonated } \\
\text { polystyrene cross-linked } \\
\text { with divinyl benzene } \\
\text { (Amberlist 15) }\end{array}$ & $\begin{array}{l}\text { Equil. limited. Temp maint. } \\
\text { below } 90 \mathrm{C} \text { to improve equil. } \\
\text { and extend cat life. Cat. very } \\
\text { specific to Isobutylene in C4 } \\
\text { mixture. Butadiene } \\
\text { polymerzizes. Water reacts with } \\
\text { isobutyene to make isobutyl } \\
\text { alcohol. } 90-096 \% \mathrm{MEOH} \\
\text { conv./pass. } 99+\% \\
\text { propylene/pass }\end{array}$ \\
\hline Carbon di & & & 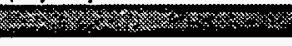 & 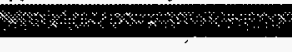 & (6) \\
\hline
\end{tabular}




\begin{tabular}{|c|c|c|c|c|c|}
\hline 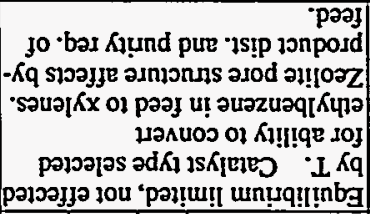 & 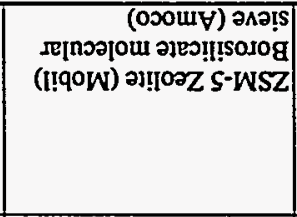 & $\begin{array}{l}\text { une } 0 z-0 I=d \\
\supset 08 t-0 \varepsilon b=\mathrm{L}\end{array}$ & 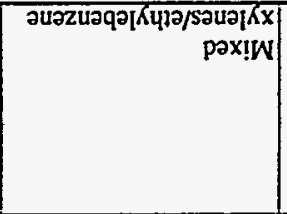 & 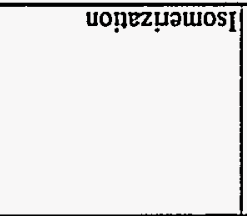 & \\
\hline 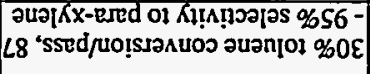 & 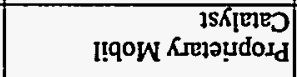 & 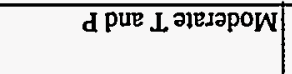 & 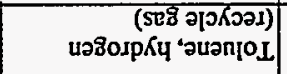 & uoṇeuo!nodds!p & วนวโKX-d \\
\hline SNA & & & & & 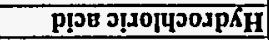 \\
\hline 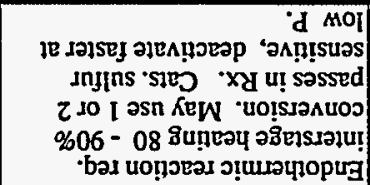 & 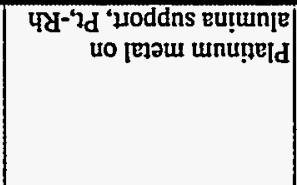 & 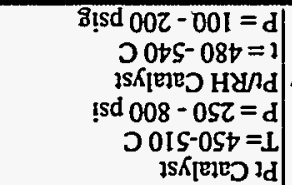 & 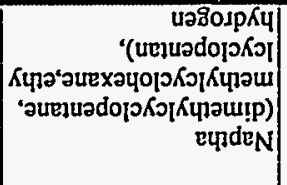 & 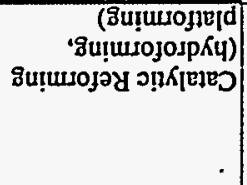 & auanjod \\
\hline 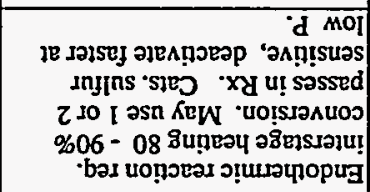 & 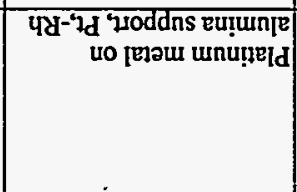 & 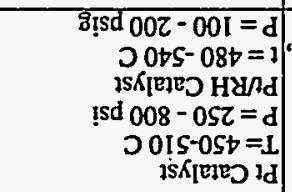 & 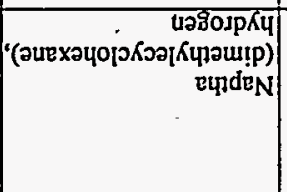 & 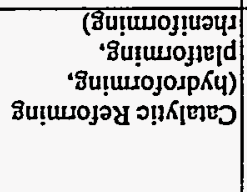 & \\
\hline 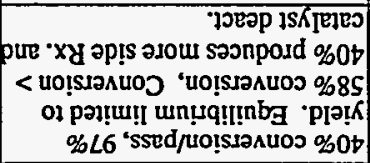 & 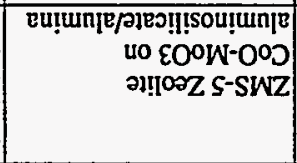 & $\begin{array}{r}\text { g! } \mathrm{Sd} 00 E=\mathrm{d} \\
\supset 0 \varepsilon S-0 S t=\mathrm{I}\end{array}$ & วนวก|0IL & uo!̣euo!̣ Lodosds!p & \\
\hline 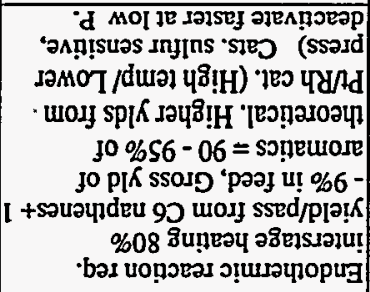 & 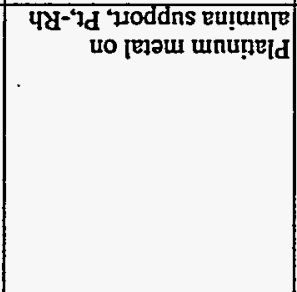 & 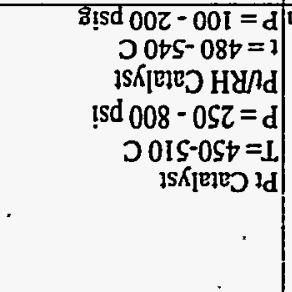 & 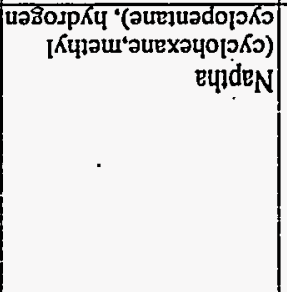 & 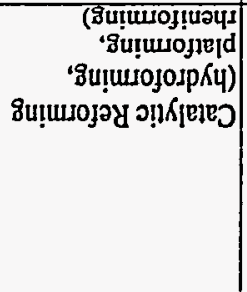 & จัग्ग $\mathrm{X}$ \\
\hline 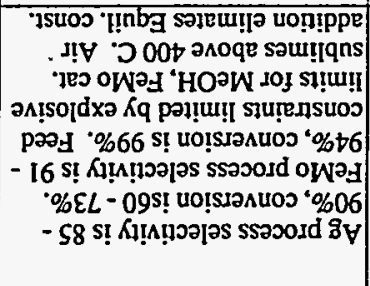 & 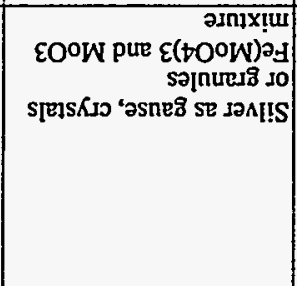 & 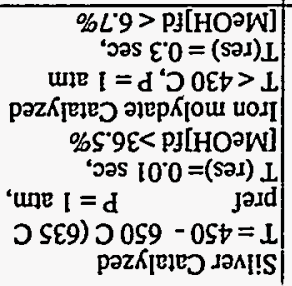 & 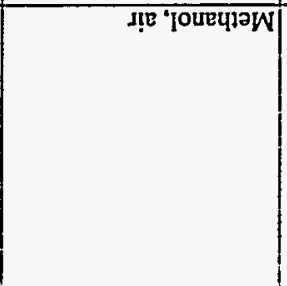 & 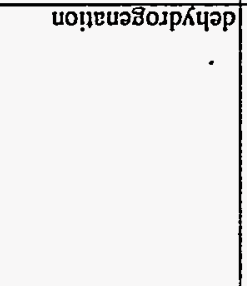 & 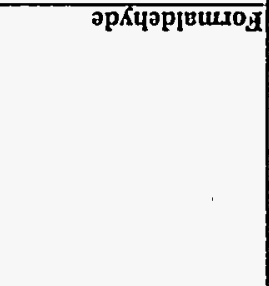 \\
\hline 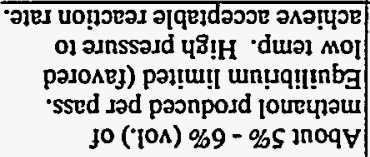 & 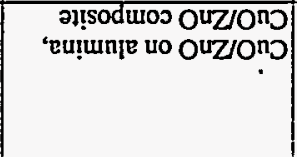 & $\begin{aligned} \operatorname{tsd} 00 S I-S Z L & =d \\
00 L Z-0 \triangleright Z & =\mathrm{L}\end{aligned}$ & 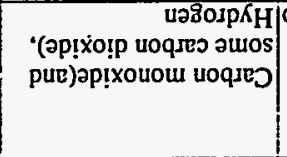 & 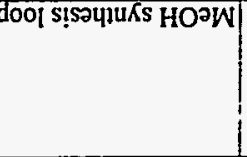 & [OUBपןग्र \\
\hline 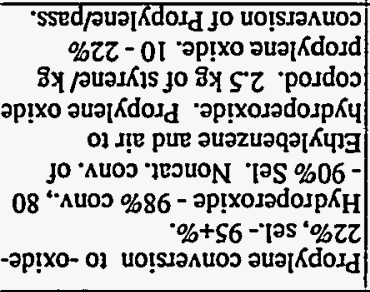 & 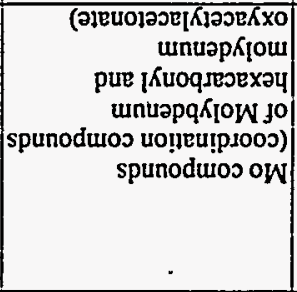 & 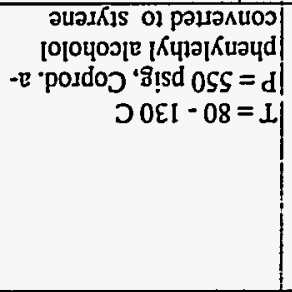 & 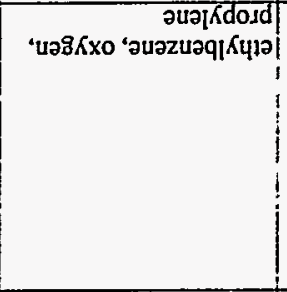 & uo!leptxosod & \\
\hline 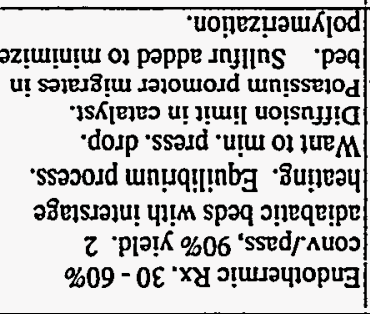 & 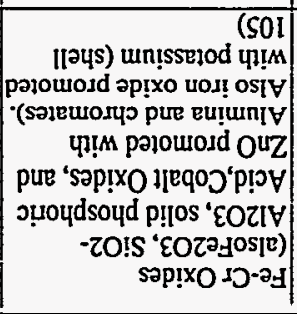 & 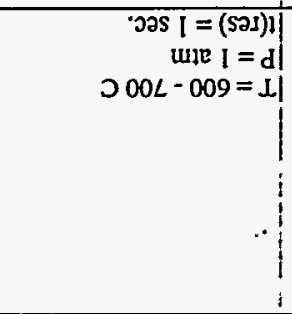 & วuวzuaqKप1] & 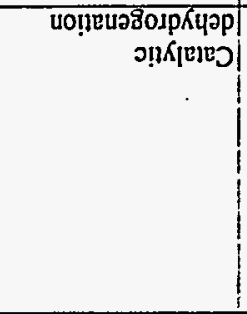 & गUगम \\
\hline SPION & 57SאโE]8D & suo!̣!̣uos siụtesado & צวо75p20Д & ssjooddqnS & [Еगุயนमนว \\
\hline
\end{tabular}


top50proc_ref.xis

\begin{tabular}{|c|c|c|c|c|c|}
\hline Chemical & Subprocess & Feedstock & Operating conditions & Catalysts & Notes \\
\hline \multirow[t]{2}{*}{ Terephthalic acid } & air oxidation & P-xylene, air & $\begin{array}{l}\text { Br salt promoted } \mathrm{T}= \\
200 \mathrm{C}, \mathrm{P}=225-400 \mathrm{psi} \\
\text { Acetaldehyde promoted } \\
\mathrm{T}=120-175 \mathrm{C} \\
\mathrm{P}=100-200 \text { psig } \\
\mathrm{MEK} \text { promoted } \\
\mathrm{T}=95-150 \mathrm{C}, \mathrm{P}=5- \\
150 \text { psig }\end{array}$ & $\begin{array}{l}\text { cobalt and manganes } \\
\text { salts of heaymetal. } \\
\text { bromides }\end{array}$ & $\begin{array}{l}99.6 \% \text { purity and } 90-95 \% \text { yield } \\
90 \% \text { sel. at } 95 \% \text { yld). Acetic } \\
\text { acid used as solvent in Proc. } \\
\text { Purity improved by } \\
\text { hydrogenation of formylbenzoic } \\
\text { acid impurity to p- } \\
\text { methylbenzoic acid and } \\
\text { crystallization. } 99.9 \% \text { pure } \\
\text { product }\end{array}$ \\
\hline & disproportionation & Potassium benzoate, & $\begin{array}{l}\text { liquịd phase } \mathrm{CO} 2 \text { at } 740 \text {. } \\
\text { psi }\end{array}$ & $\begin{array}{l}\text { Zn and Cd compounds } \\
(\mathrm{CdO})\end{array}$ & $\begin{array}{l}\text { Reaction takes place in } \mathrm{CO} 2 \\
\text { atm. }\end{array}$ \\
\hline Ethylene oxide & $\begin{array}{l}\text { oxidation } \\
\text { (epoxidation) }\end{array}$ & Ethylene, air, oxygen & $\begin{array}{l}\mathrm{T}=260-280 \mathrm{C} \text { (air) } \\
\mathrm{T}=230 \mathrm{C} \text { (oxygen) } \\
\mathrm{P}=1-3 \mathrm{MPa} \\
\mathrm{t}(\mathrm{res})=1 \text { sec. }\end{array}$ & Silver, with trace of Cs & $\begin{array}{l}10-15 \% \text { conversion/pass. } 88- \\
94 \% \text { selectivity reported using } \\
\text { alkali metal cations in, on or } \\
\text { under silver particles on alumina } \\
\text {. Carbon dioxide inhibits Rx. } \\
\text { removed in an absorber before } \\
\text { stream recycle. Lower temp. } \\
\text { favors selectivity and } \\
\text { conversion. }\end{array}$ \\
\hline \multirow{2}{*}{\begin{tabular}{|l|} 
Ethylene glycol \\
Ammonium sulfate \\
\end{tabular}} & Hydration & Ethlene oxide, water & $\begin{array}{l}\mathrm{T}=50-100 \mathrm{C} \\
\mathrm{t}(\mathrm{res})=30 \mathrm{~min}, \\
\text { Ethylene/water }=10 / 1\end{array}$ & $0.5-1.0 \% \mathrm{H} 2 \mathrm{SO} 4$ & $\begin{array}{l}100 \% \text { yield of products with } \\
\text { about } 10 \% \text { of product di- and } \\
\text { triethylene glycol ethers }\end{array}$ \\
\hline & \multicolumn{5}{|c|}{ 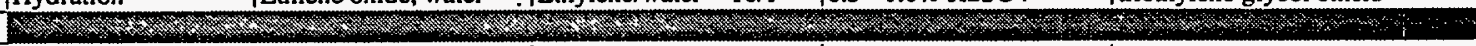 } \\
\hline Cumene & Alkylation & Benzene, Propylene & $\begin{array}{c}\vdots \\
T=200-250 \mathrm{C} \\
\mathrm{P}=400-600 \mathrm{psi}\end{array}$ & H2PO4 on kieselguhr & $\begin{array}{l}96-97 \% \text { yield on Benzene. } 91 \\
92 \% \text { yield on propylene. Excess } \\
\text { benzene used to minimize di- } \\
\text { isopropylene benzene formation } \\
\text { which must further react with } \\
\text { benzene to produce cumene in a } \\
\text { separate step. Cat. distillation } \\
\text { process recently demonstrated. }\end{array}$ \\
\hline \multicolumn{6}{|l|}{ Potash } \\
\hline Phenol & Cumene Peroxidation & Cumene, air & $\begin{array}{l}\text { Peroxidation } \\
\mathrm{T}=100-130 \mathrm{C}(130- \\
140 \mathrm{C}) \mathrm{P}=25-\mathrm{psig}(20 \\
-250 \text { psi }) \\
\text { Decomposition } \\
\mathrm{T}=60-80 \mathrm{C} \\
\mathrm{P}=5 \mathrm{psig} \\
\mathrm{t}(\mathrm{res})=15 \mathrm{~min} .\end{array}$ & $\begin{array}{l}\text { l. } \\
\begin{array}{l}\text { Peroxidation - metal salts } \\
(?) \\
\text { decomposition - mineral } \\
\text { acid }(\mathrm{H}+)\end{array} \\
\end{array}$ & $\begin{array}{l}30-50 \% \text { conversion/pass and } \\
85-95 \% \text { yield of cumene } \\
\text { hydroperoxide intermediate. } 90 \\
-95 \% \text { yield of phenol from } \\
\text { hydroperoxide itermediate. } 90 \\
-98 \% \text { overall yield. } \\
\text { Exothermic. } 91 \text { - } 93 \% \text { overall } \\
\text { yield of acetone coproduct. } \\
\text { Other byproducts made. }\end{array}$ \\
\hline \multirow[t]{3}{*}{ Acetic acid } & $\begin{array}{l}\text { Acetaldehyde } \\
\text { oxidation }\end{array}$ & $\begin{array}{l}\text { Ethylene, Oxygen (air) } \\
\text { (acetaldehyde is an } \\
\text { intermediate product in } \\
\text { integrated system) } \\
\end{array}$ & $\begin{array}{l}\text { Ethylene oxidation } \\
\mathrm{T}=130 \mathrm{C} \\
\mathrm{P}=45 \mathrm{psig} \\
\text { Acetaldehyde oxidation } \\
\mathrm{T}=66 \mathrm{C} \\
\mathrm{P}=\text { liquid phase (about } \\
15 \text { psi }-75 \mathrm{psi} \text { ) }\end{array}$ & $\begin{array}{l}\text { Ethylene Oxidation - } \\
\text { CuCl2 and } \mathrm{PdCl} 2 \\
\text { Acetaldehyde oxidation - } \\
\mathrm{Mn}(\mathrm{OAC}) 2 \text { or } \mathrm{Co}(\mathrm{OAc}) 2\end{array}$ & $\begin{array}{l}95 \% \text { yield of Acetaldehyde from } \\
\text { ethylene. } 95 \% \text { yield of acetic } \\
\text { acid from acetaldehyde with up } \\
\text { to } 50 \% \text { conversion/pass. } \\
\text { Homogeneous cat. }\end{array}$ \\
\hline & n-butane oxidation & $\begin{array}{l}95 \% \text { n-butane (2.5\% } \\
\text { isobutane, } 2.5 \% \\
\text { pentane), air (air/butane } \\
=5 / 1) \text {, Europe uses } \\
\text { pentane and hexane } \\
\text { feedstocks }\end{array}$ & $\begin{array}{l}\mathrm{T}=50-250 \mathrm{C} \\
\mathrm{P}=800 \mathrm{psi}\end{array}$ & $\begin{array}{l}\text { Cobalt, manganese or } \\
\text { chromium acetate }\end{array}$ & $\begin{array}{l}75-80 \% \text { selectivity (6\% formic } \\
\text { acid, } 6 \% \text { ethanol, } 4 \% \text { methanol, } \\
4-9 \% \text { other). Homogeneous } \\
\text { cat. Process conditions can be } \\
\text { modified to emphasize formic } \\
\text { acid or MEK production at } \\
\text { expense of acetic acid. }\end{array}$ \\
\hline & $\begin{array}{l}\text { Methanol } \\
\text { Carbonylation }\end{array}$ & Imethanol, $\mathrm{CO}$ & $\begin{array}{l}T=150-200 \mathrm{C}(175 \mathrm{C}) \\
\mathrm{P}=100-215 \mathrm{~atm} .(1 \\
\text { atm) }\end{array}$ & $\begin{array}{l}\text { Rhodium and iodine } \\
\text { catalyst system }\end{array}$ & $\begin{array}{l}99+\% \text { yield based on methanol, } \\
90+\% \text { yield based on CO. } \\
+ \text { Leach } 1983 \text { gives good } \\
\text { discussion of catalytic Rx. }\end{array}$ \\
\hline
\end{tabular}




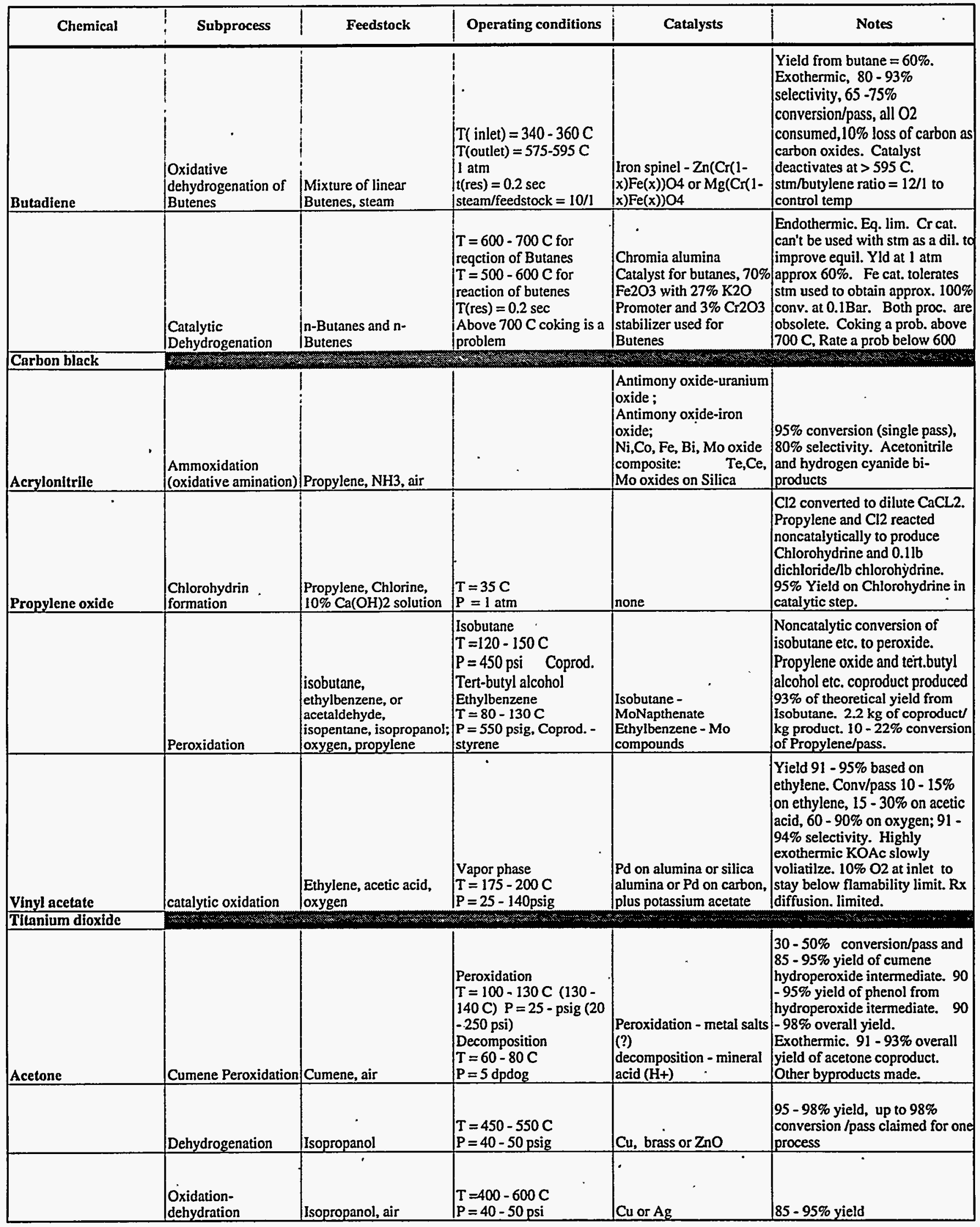


top50proc_ref.xls

\begin{tabular}{|c|c|c|c|c|c|}
\hline Chemical & Subprocess & Feedstock & Operating conditions & Catalysts & Notes \\
\hline Cyclohexane & Hydrogenation & lbenzene, hydrogen & $\begin{array}{l}\text { Ni on alumina } \\
\mathrm{T}=150-220 \mathrm{C} \\
\mathrm{P}=300-450 \mathrm{psi} \\
\text { Sulfided nickel or } \mathrm{Pd} \\
\mathrm{T}=450 \mathrm{C} \\
\mathrm{P}=4500 \mathrm{psi}\end{array}$ & supported $\mathrm{Ni}, \mathrm{Pd}, \mathrm{Pt}$ & $\begin{array}{l}99.6 \% \text { yield. Highly } \\
\text { exothermic, several adiabatic } \\
\text { beds. Favored by low temp. } \\
\text { Isomerization at higher temp. } \\
\text { Appears to be a single pass } \\
\text { process for benzene. Product } \\
\text { irecycled to cool reaction. }\end{array}$ \\
\hline \begin{tabular}{|l|} 
Aluminum sulfate \\
Sodium silicate \\
\end{tabular} & \multicolumn{5}{|c|}{ PXo } \\
\hline Adipic acid & catalytic oxidation & $\begin{array}{l}\text { cyclohexane } 98 \% \text { purity } \\
\text { air and nitric acid } \\
\end{array}$ & $\begin{array}{l}\text { Hexane oxidation } \\
\mathrm{T}=125-160 \mathrm{C} \\
\mathrm{P}=50-250 \mathrm{psi} \\
\text { Hexanol } / \text { Hexone } \\
\text { Oxidation } \\
\mathrm{T}=50-90 \mathrm{C} \\
\mathrm{p}=1-4 \mathrm{~atm} \\
\mathrm{t}(\mathrm{res})=10-30 \mathrm{~min}\end{array}$ & $\begin{array}{l}\text { cobalt (II) napthenate or } \\
\text { acetate } \\
\text { Second step } \\
\text { amonium vanadate and } \\
\text { copper }\end{array}$ & $\begin{array}{l}10 \% \text { conversion/pass of } \\
\text { cyclohexane to } \\
\text { cyclohexanol/cyclohexanone } \\
\text { intermediate to get a } 65 \%-90 \% \\
\text { yield. Boric acid additive } \\
\text { improves selectivity to } \\
\text { intermediates. Overall yield of } \\
\text { adipic acid } 90-95 \% \text {. removal of } \\
\text { H2O byproduct essential to high } \\
\text { yields }\end{array}$ \\
\hline & catalytic oxidation & cyclohexane, air & $\begin{array}{l}\mathrm{T}=90 \mathrm{C} \\
\mathrm{P}=\text { liquid phase } \\
\mathrm{t}(\mathrm{res})-9 \mathrm{hr} \\
\text { in acetic acid }\end{array}$ & Cobalt acetate & $\begin{array}{l}88 \% \text { overall conversion, } 73 \% \\
\text { yield. Acetic acid is } \mathrm{Rx} . \\
\text { medium. }\end{array}$ \\
\hline Calcium chloride & \multicolumn{5}{|c|}{ 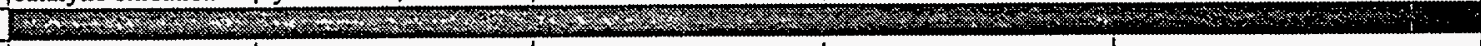 } \\
\hline Caprolactam & $\begin{array}{l}\text { Beckman } \\
\text { rearrangement }\end{array}$ & $\begin{array}{l}\text { Cyclohexanone (from } \\
\text { cyclohexane [58\%] or } \\
\text { phenol [42\%]). } \\
\text { hydroxylamine( made } \\
\text { fromNH3, CO2, S, air) }\end{array}$ & $\mathrm{T}=100-200 \mathrm{C}$ & sulfuric acid & $\begin{array}{l}90 \% \text { yield (single pass). } \\
\text { Ammonium sulfate by product } \\
\text { produced ( phosporic acid to } \\
\text { produce ammonium phosphate } \\
\text { also used). }\end{array}$ \\
\hline Sodium sulfate & \multicolumn{5}{|c|}{ 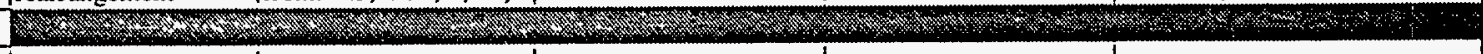 } \\
\hline Isobutylene & Isomerization & n-butanes & & & $90 \%$ yield from butane (iso?) \\
\hline & |dehydration & tert-butyl alcohol & & & $\begin{array}{l}\text { Tert. butyl alcohol coproduced } \\
\text { with propylene oxide from } \\
\text { prpoylene }\end{array}$ \\
\hline
\end{tabular}




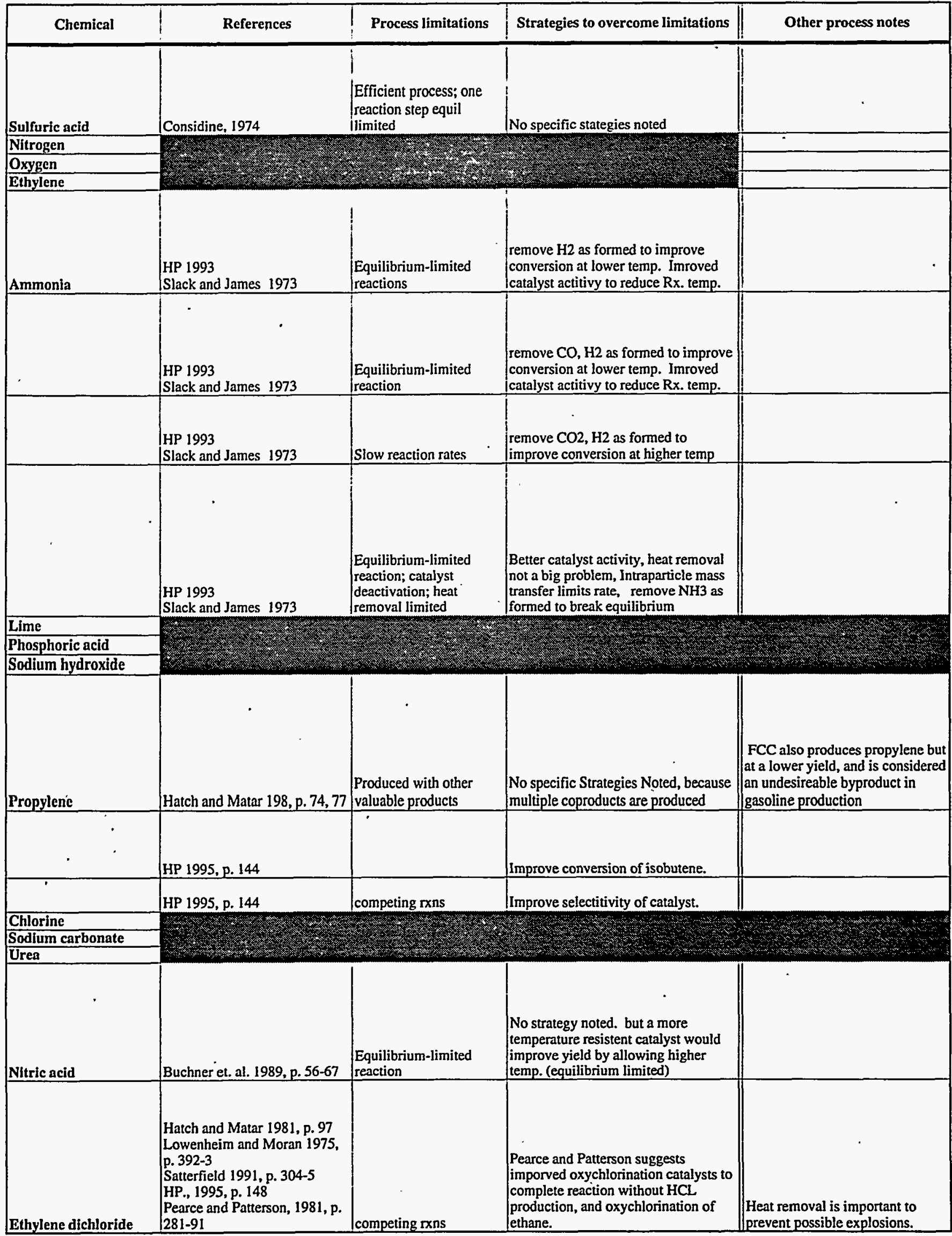


top50proc_ref.xls

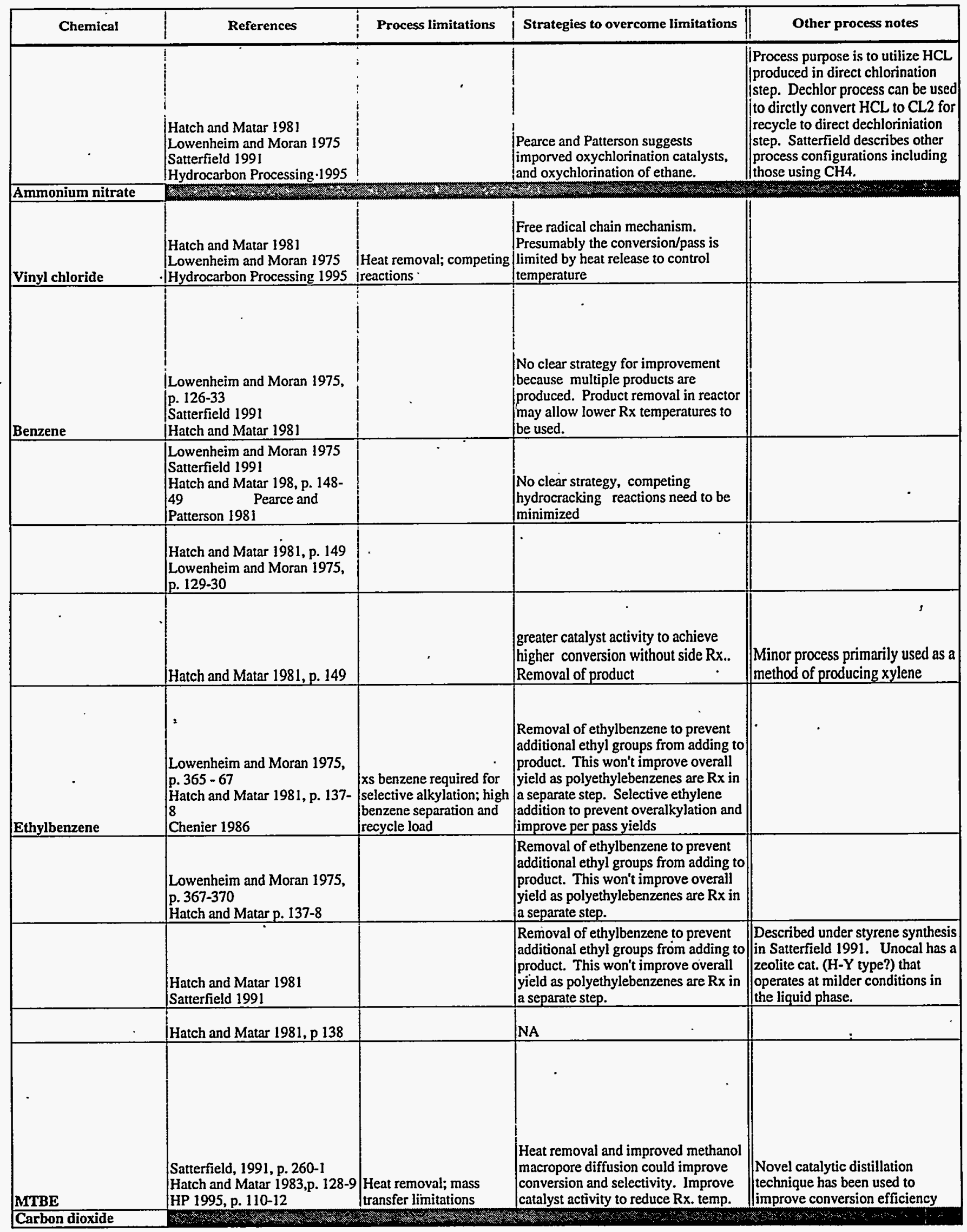


top50proc_rel.x/s

\begin{tabular}{|c|c|c|c|c|}
\hline Chemical & References & Process limitations & Strategies to overcome limitations & Other process notes \\
\hline Styrene & $\begin{array}{l}\text { Hatch and Mater 1981, p. 138- } \\
40 \\
\text { Satterfield 1991, p. 403-5 } \\
\text { Lowenheim and Matar 1975, p. } \\
779-82\end{array}$ & Equilibrium-limited; heat & \begin{tabular}{|l|} 
\\
Improve heat addition methods. \\
Reduce diffusion limitation in catalyst. \\
Separate hydrogen as it forms to break \\
equilibrium
\end{tabular} & $\begin{array}{l}\text { Noncatalytic (?) Epoxidation } \\
\text { process (Chenier accts for } 17 \% \text { of } \\
\text { production(1986) by oxidizing } \\
\text { ethylbenzene and reacting with } \\
\text { propylene to produce Propylene } \\
\text { oxide and an alcohol dehydrated } \\
\text { to styrene }\end{array}$ \\
\hline & $\begin{array}{l}\text { Chenier } 1986 \\
\text { Hatch and Matar } 1981 \\
\text { Satterfield 1991 } \\
\text { Lowenheim and Moran 1975, } \\
\text { p. } 111 \\
\text { Pearce and Patterson } 1981 \\
\end{array}$ & & $\begin{array}{l}\text { improve selectivity of catalyst to } \\
\text { |coproducts }\end{array}$ & $\begin{array}{l}\text { A titanium oxide catalyst may be } \\
\text { required to dehyrogenate } \\
\text { phenylmethylcarbinol to styrene } \\
\text { at } 180-280 \mathrm{C}\end{array}$ \\
\hline Methanol & $\begin{array}{l}\text { Hatch and Matar 1981 } \\
\text { Satterfield 1991 } \\
\text { Pearce and Patterson 1981 } \\
\text { Hydrocarbon Processing 1995. }\end{array}$ & $\begin{array}{l}\text { Equilibrium-limited; } \\
\text { slow kinetics at low } \\
\text { temperatures }\end{array}$ & $\begin{array}{l}\text { remove } \mathrm{CO}, \mathrm{H} 2 \text { as formed to improve } \\
\text { conversion at lower temp Improve } \\
\text { catalyst activity to lower temp. } \\
\text { Separate methanol as it is formed to } \\
\text { break equilibrium }\end{array}$ & \\
\hline Formaldehyde & $\begin{array}{l}\text { Hatch and Matar } 1981 \\
\text { Pearch and Patterson } 1981 \\
\text { Lowenheim and Moran } 1975\end{array}$ & $\begin{array}{l}\text { Equilibrium-limited and } \\
\text { unfavorable kinetics for } \\
\text { undesired reactions. }\end{array}$ & $\begin{array}{l}\text { catalyst improvement. Direct route } \\
\text { from methane. Separate product as it } \\
\text { is formed. }\end{array}$ & $\begin{array}{l}\text { Satterfield notes that direct } \\
\text { synthesis from methane has been } \\
\text { tried but formaldehyde more } \\
\text { reactive than methane (rapid } \\
\text { quench or removal would make it } \\
\text { more practical). Lowenheim and } \\
\text { Moran describe methan } \\
\text { conversion process. }\end{array}$ \\
\hline \multirow[t]{4}{*}{ Xylene } & $\begin{array}{l}\text { Faith et. al } 1975 \\
\text { Satterfield 1991 } \\
\text { Hatch and Matar } 1981 \\
\end{array}$ & - & $\begin{array}{l}\text {. } \\
\text { No clear strategy for improvement } \\
\text { because multiple products are } \\
\text { produced. Product removal in reactor } \\
\text { may allow lower Rx temperatures to } \\
\text { be used. }\end{array}$ & . \\
\hline & Hatch and Matar 1981, p. 149 & & $\begin{array}{l}\text { greater catalyst activity to achieve } \\
\text { higher conversion without side } \mathrm{Rx} \text {.. } \\
\text { Removal of product }\end{array}$ & $\begin{array}{l}\text { Minor process primarily used as a } \\
\text { method of producing benzene }\end{array}$ \\
\hline & $\begin{array}{l}\text { Faith et. al } 1975 \\
\text { Satterfield 1991 } \\
\text { Hatch and Matar } 1981 \\
\end{array}$ & & $\begin{array}{l}\text { No clear strategy for improvement } \\
\text { because multiple products are } \\
\text { produced. Product removal in reactor } \\
\text { may allow lower Rx temperatures to } \\
\text { be used. }\end{array}$ & \\
\hline & $\begin{array}{l}\text { Chenier } 1986 \\
\text { Faith et. al } 1975 \\
\text { Satterfield } 1991 \\
\text { Hatch and Matar 1981 }\end{array}$ & & $\begin{array}{l}\text { No clear strategy for improvement } \\
\text { because multiple products are } \\
\text { produced. Product removal in reactor } \\
\text { may allow lower Rx temperatures to } \\
\text { be used. }\end{array}$ & $\begin{array}{l}\text { Very little difference between the } \\
\text { toluene and benzene reforming } \\
\text { routes except for the composition } \\
\text { of the feed, and subsequent } \\
\text { separations. }\end{array}$ \\
\hline \multirow[t]{2}{*}{ p-Xylene } & Petrochemical Handbook 1991 & Equilibrium-limited & $\begin{array}{l}\text { No clear strategy other than further } \\
\text { improvment of catalyst selectivity. } \\
\text { product removal may improve } \\
\text { equilibrium (see xylene) }\end{array}$ & \\
\hline & $\begin{array}{l}\text { Hatch and Matar } \\
\text { Satterfield } 1991\end{array}$ & & $\begin{array}{l}\text { Efficient removal of p-xylene as } \\
\text { produced would improve yield. }\end{array}$ & $\begin{array}{l}\text { References in Satter field on } \\
\text { processes ( } p .374)\end{array}$ \\
\hline
\end{tabular}


top50proc_ref.xls

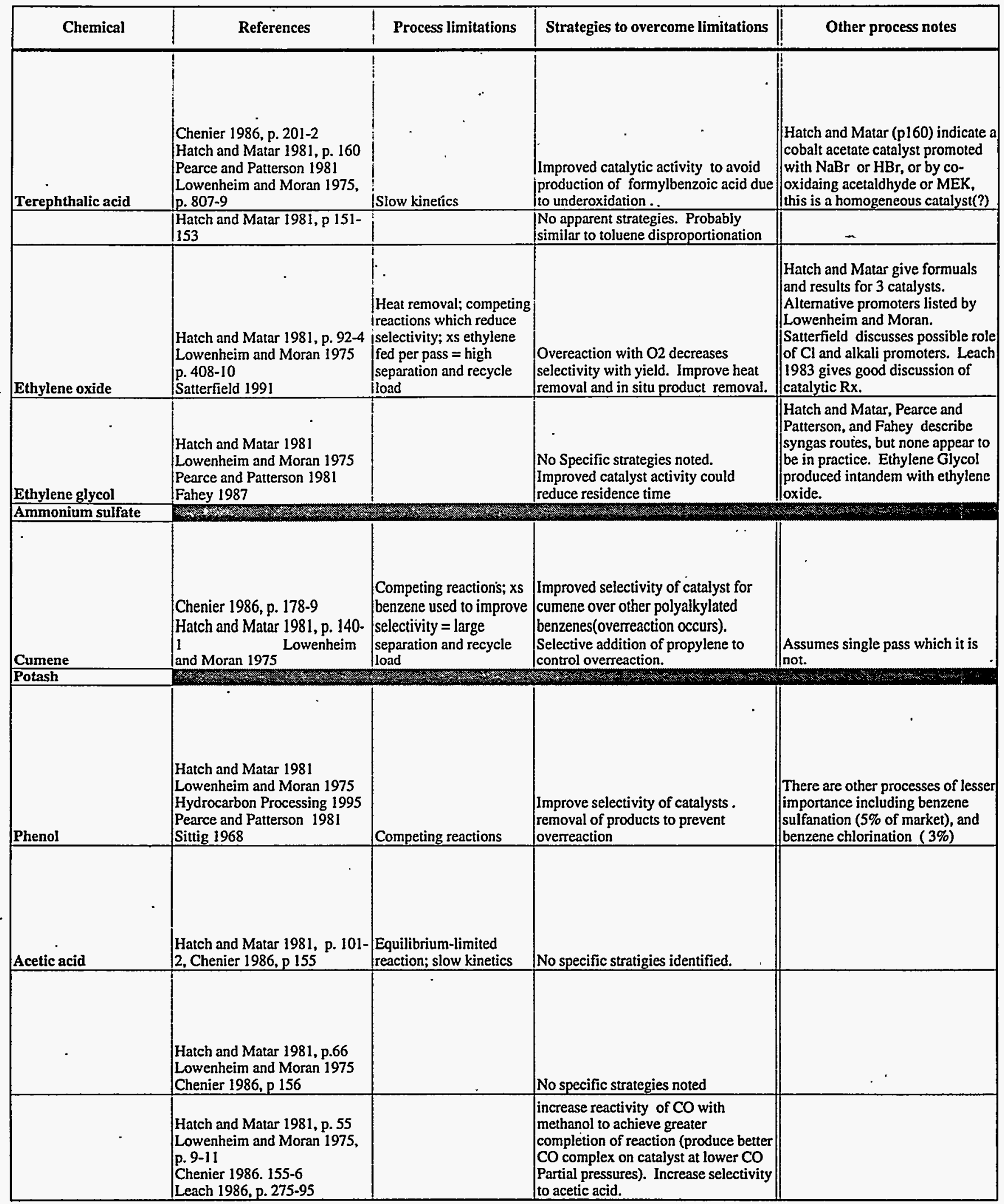




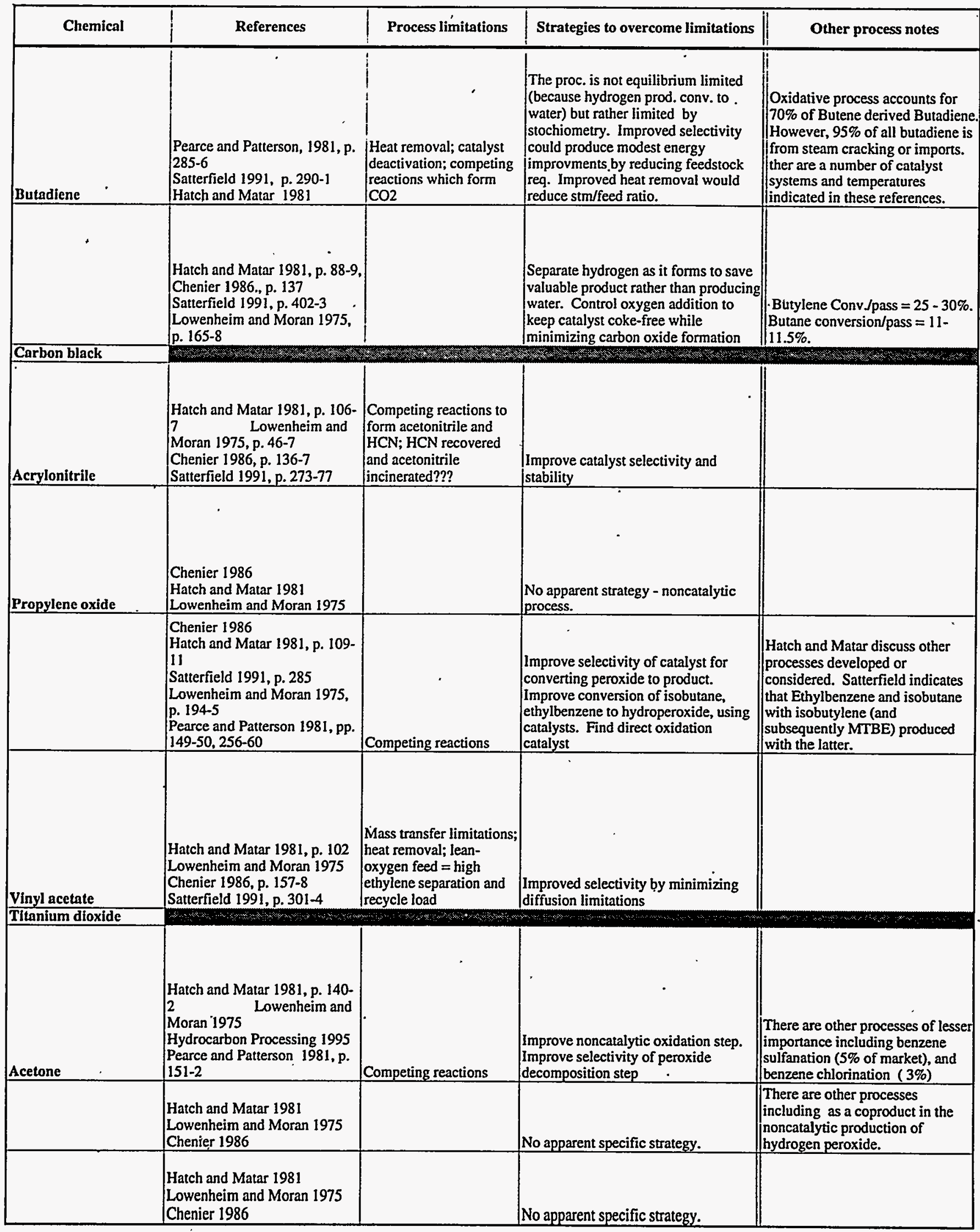


top50proc_ref.xls

\begin{tabular}{|c|c|c|c|c|}
\hline Chemical & References & Process limitations & Strategies to overcome limitations & Other process notes \\
\hline Cyclohexane & $\begin{array}{l}\text { Hatch and Matar } 1981 \\
\text { Lowenheim and Moran } 1975 \\
\text { Chenier } 1986 \\
\text { Satterfield } 1991\end{array}$ & Heat removal & $\begin{array}{l}\text { improved heat removal to reduce } \\
\text { isomerization }\end{array}$ & \\
\hline $\begin{array}{l}\text { Aluminum sulfate } \\
\text { Sodium silicate } \\
\end{array}$ & i & 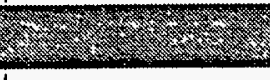 & & \\
\hline Adipic acid & $\begin{array}{l}\text { Hatch and Matar 1981, p. } 146 \\
\text { Lowenheim and Moran 1975, } \\
\text { p. 50-54 } \\
\text { Pearce and Patterson 1981, p. } \\
146\end{array}$ & $\begin{array}{l}\text { Competing reactions; } \\
\text { heat removal }\end{array}$ & $\begin{array}{l}\text { Improve selectivity of catalyst to } \\
\text { produce hexanol/ hexanone } \\
\text { intermediate or remove intermediate } \\
\text { as formed. Improve selectivity of cat. } \\
\text { for oxidation of intermediates. }\end{array}$ & preferred route \\
\hline & Hatch and Matar 1981 & & Better catalyst specificity & \\
\hline Calcium chloride & \multicolumn{4}{|c|}{ 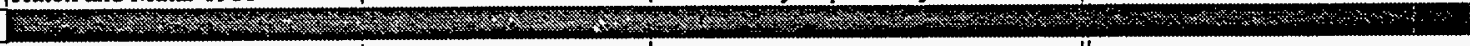 } \\
\hline Caprolactam & $\begin{array}{l}\text { Lowenheim and Moran } 1975 \text {, } \\
\text { p. 201-3 } \\
\text { Chenier } 1986\end{array}$ & Competing reactions & $\begin{array}{l}\text { Improve selectivity. Selectivity may } \\
\text { be due to over reaction or competing } \\
\text { reactions. }\end{array}$ & $\begin{array}{l}\text { Cyclohexanone can be made from } \\
\text { cyclohexanol by dehydration over } \\
\text { a zinc cat. (using the } \\
\text { cyclohexanol/cyclohexanone } \\
\text { intermediate from adiptic acid } \\
\text { route. Made from phenol by } \\
\text { hydrogenation over Pd on carbon } \\
\text { cat. ther are other processes not } \\
\text { used in US. }\end{array}$ \\
\hline Sodium sulfate & \multicolumn{4}{|c|}{ 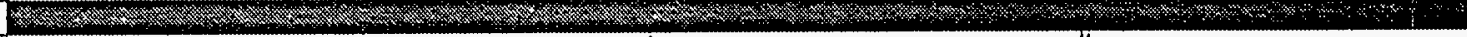 } \\
\hline Isobutylene & HP 1995 & $\begin{array}{l}\text { kinetics to competing } \\
\text { Ixns, cat. deactivation; } \\
\text { heat addition }\end{array}$ & & \\
\hline & $\begin{array}{l}\text { Chenier 1986, p } 175 \\
\text { Hatch and Matar } 1981 \text { p } 111\end{array}$ & & & \\
\hline
\end{tabular}




\section{Distribution}

\section{No of}

Copies

2 DOE/Office of Scientific and

Technical Information

50 David Boron

U.S. Department of Energy

Forrestal Building

1000 Independence Ave. SW.

MS EE232, 5F-043

Washington, D.C. 20585
No of

Copies

60 Pacific Northwest Laboratory

E.G. Baker, P8-38

M.A. Gerber, P8-38

S.J. Ortiz, P8-38

- L.J. Sealock, Jr., K2-10

A.L.Y. Tonkovich, P8-38 (50)

J.E. Widrig, K8-11

Technical Report Files (5) 